\title{
Low-Cost Conformable Storage to Maximize Vehicle Range
}

\author{
R. P. Graham
}

Thiokol Aerospace \& Industrial Technologies

NREL Technical Monitor: Bill Warnock

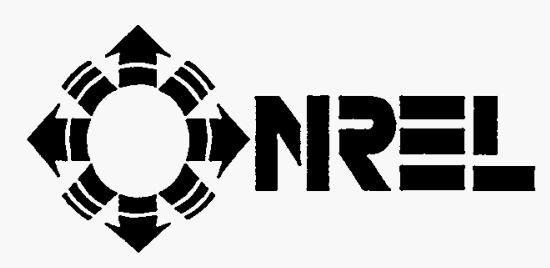

Alternative Fuels Hotline: 1-800-423-1DOE

Alternative Fuels Data Center World Wide Web Site: http://www.afdc.doe.gov

National Renewable Energy Laboratory

1617 Cole Boulevard

Golden, Colorado 80401-3393

A national laboratory of the

U.S. Department of Energy

Managed by the Midwest Research Institute

For the U.S. Department of Energy

Under Contract No. DE-AC36-83CH10093

Prepared under Subcontract Number YCF-5-14050-02

$$
\text { January } 1998
$$

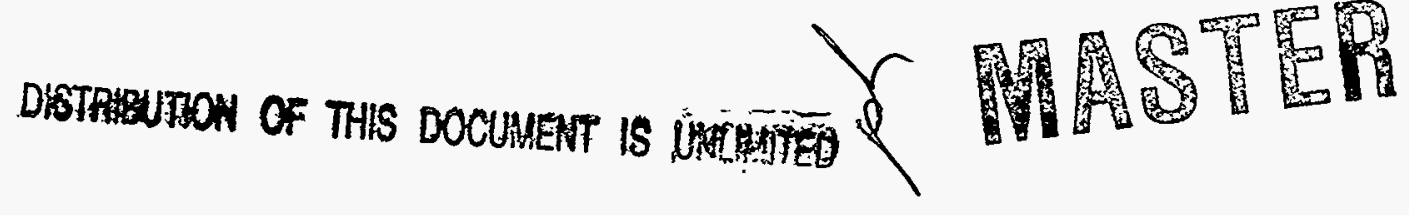




\section{NOTICE}

This report was prepared as an account of work sponsored by an agency of the United States government. Neither the United States government nor any agency thereof, nor any of their employees, makes any warranty, express or implied, or assumes any legal liability or responsibility for the accuracy, completeness, or usefulness of any information, apparatus, product, or process disclosed, or represents that its use would not infringe privately owned rights. Reference herein to any specific commercial product, process, or senvice by trade name, trademark, manufacturer, or otherwise does not necessarily constitute or imply its endorsement, recommendation, or favoring by the United States govemment or any agency thereof. The views and opinions of authors expressed herein do not necessarily state or reflect those of the United States government or any agency thereof.

Available to DOE and DOE contractors from:

Office of Scientific and Technical Information (OSTI)

P.O. Box 62

Oak Ridge, TN 37831

Prices available by calling (423) 576-8401

Available to the public from:

National Technical Information Service (NTIS)

U.S. Department of Commerce

5285 Port Royal Road

Springfield, VA 22161

(703) $487-4650$ 


\section{DISCLAIMER}

Portions of this document may be illegible electronic image products. Images are produced from the best available original document. 


\section{TABLE OF CONTENTS}

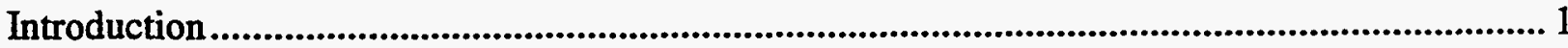

Project Information............................................................................................................... 1

Conformable Storage Concept...................................................................................................... 1

Material Selection and Development........................................................................................... 2

Material Properties .................................................................................................................. 2

Molded Bar Tests ....................................................................................................................... 3

Tube Burst Tests ....................................................................................................................... 3

Dissected Tank Tests............................................................................................................................ 4

Primary Candidate Materials..............................................................................................

System Design ............................................................................................................................ 5

Design Requirements................................................................................................................... 5

Design Verification and Qualification Tests............................................................................ 6

Production Verification ......................................................................................................... 6

Subscale Tank Design and Analysis.................................................................................... 7

Subscale Design 1................................................................................................................

Port Sealing........................................................................................................................ 8

Intermediate Design........................................................................................................... 8

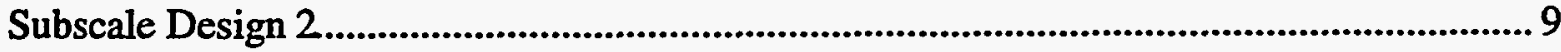

Full-Scale Tank Design....................................................................................................... 10

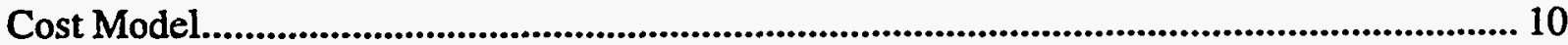

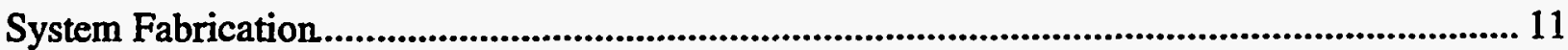

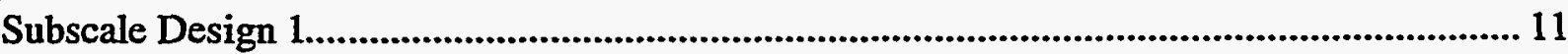

First Molding Run ................................................................................................................. 11

Molding Process Changes................................................................................................... 12

Second Molding Run............................................................................................................ 13

Subscale Design 2

Fabrication Methods ............................................................................................................ 14

Cup Welding...................................................................................................................... 14

Process Improvement ............................................................................................................. 15

Vibrational Molding.................................................................................................................. 15

Experimental Program ....................................................................................................... 15

Subscale Tank Design 1........................................................................................................ 15

Burst and Cyclic Pressure Tests................................................................................. 15

Impact Tests..................................................................................................................... 16

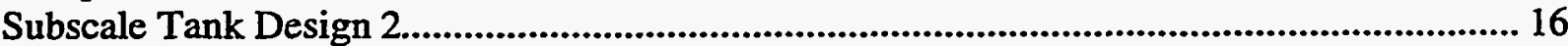

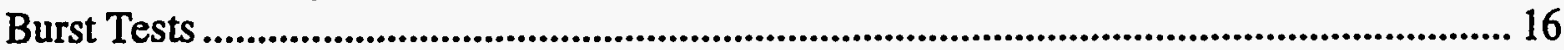

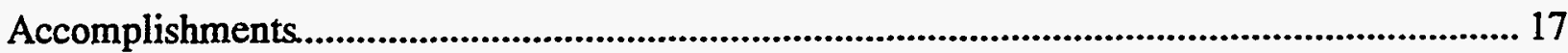

The Future ....................................................................................................................... 18

Structural Reaction Injection Molding.................................................................................. 18

Higher Strength Thermoplastic Development....................................................................... 18

Fabric-Reinforced Thermoplastic Injection Molding................................................................... 19

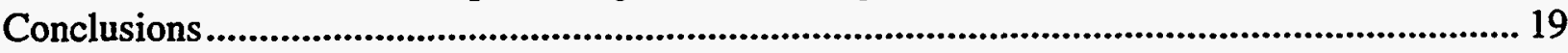

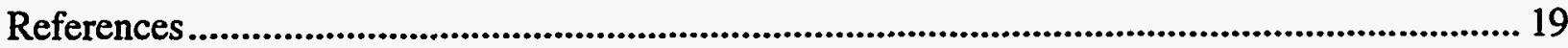




\section{TABLES}

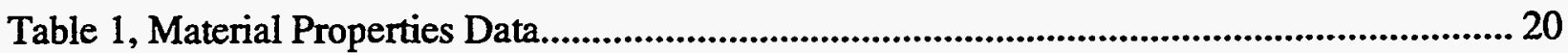

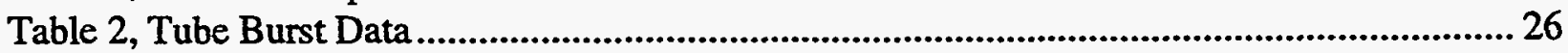

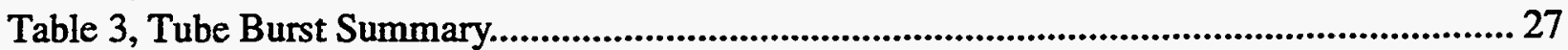

Table 4, Tank Dissect, RTP2399 x 68911A Polyurethane, Tensile Bars...................................... 27

Table 5, Tank Dissect, AMODEL A-1133 HS Polyphthalamide.................................................. 27

Table 6, Tank Design Requirements........................................................................................ 28

Table 7, Design Verification and Qualification Tests.................................................................... 29

Table 8, Production Verification Tests.................................................................................. 30

Table 9, Analysis Input Properties.................................................................................................. 30

Table 10, Finite Element Analysis Results, Original Subscale Design......................................... 31

Table 11, Analysis Iterations for Second Subscale Design............................................................ 31

Table 12, Cost Model for Aluminum Tank ................................................................................ 32

Table 13, Cost Model for AMODEL AS-1133 HS Tank.............................................................. 33

Table 14, Cost Model for FORTRON 0214 C1 Tank ..................................................................... 34

Table 15, Cost Model for Target Material ..................................................................................... 35

Table 16, Molding Results, Subscale Design 2.......................................................................... 36

Table 17, Welded Bottle Burst Summary ...................................................................................... 36

Table 18, Tank Burst Tests, First Subscale Design....................................................................... 37

Table 19, Impact Test Results............................................................................................. 37

Table 20, Target Properties for Material Development............................................................... 37

\section{FIGURES}

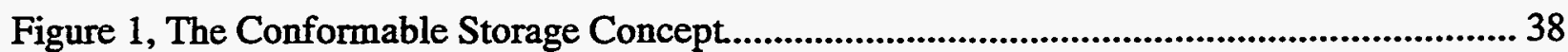

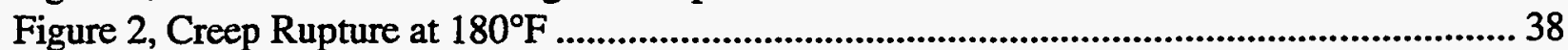

Figure 3, Cup Mold and Tube Burst Test ........................................................................................ 39

Figure 4, Tube Burst Results............................................................................................................... 39

Figure 5, Propane Pressure versus Temperature .......................................................................... 40

Figure 6, First Subscale Tank Design.......................................................................................... 40

Figure 7, Shell Element Model of First Subscale Tank............................................................. 41

Figure 8, Axisymmetric Model of First Subscale Tank.............................................................. 41

Figure 9, Cross Section Plane Strain Model of First Subscale Tank............................................. 42

Figure 10, 3-D Solid Element Model of First Subscale Tank.......................................................... 42

Figure 11, Port Fitting Designed to Eliminate Leakage.................................................................. 43

Figure 12, Port Fitting Seals Against Plastic Face........................................................................ 43

Figure 13, Boss Seal Gap Opening Analysis .............................................................................. 44

Figure 14, Intermediate Subscale Tank Design......................................................................... 45

Figure 15, Design Strength for Subscale Tank Design 2.......................................................... 45

Figure 16, Subscale Tank Design 2......................................................................................... 46

Figure 17, Stress Analysis for Design 2, Inside.......................................................................... 47 


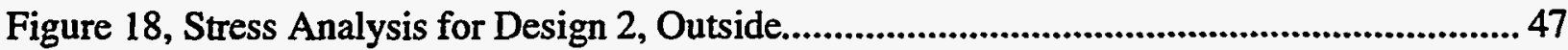

Figure 19, Full Scale Tank Design ................................................................................................ 48

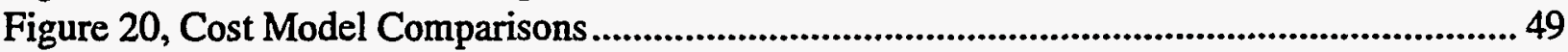

Figure 21, Original Injection Mold.............................................................................................. 49

Figure 22, Sand Core Failures.................................................................................................5 50

Figure 23, Molding Process Improvements..............................................................................5 50

Figure 24, Redesigned Boss............................................................................................................51

Figure 25, Injection Mold for Subscale Tank ...................................................................................5 52

Figure 26, Sand Cores in Injection Mold....................................................................................5 53

Figure 27, Runner System for Balanced Injection at Both Ends....................................................5 54

Figure 28, Mold Opened after Molding Part................................................................................... 55

Figure 29, Design 2, Tank \#1, Dissected.....................................................................................5 56

Figure 30, Design 2, Tank \#20, After Burst Test..................................................................... 57

Figure 31, Welded Bottle Test ................................................................................................58

Figure 32, Weld Tests for AMODEL A-1133 HS.....................................................................5 59

Figure 33, Weld Tests for RTP 4005.........................................................................................5 59

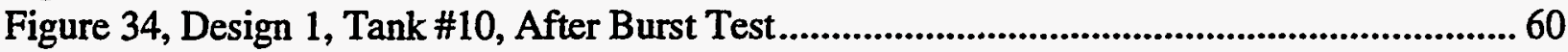

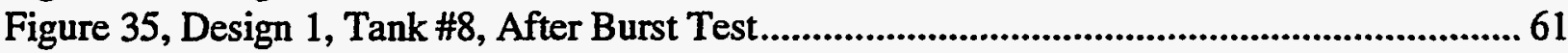

Figure 36, Design 2, Tank \#21, Reassembled After Burst Test.................................................... 62

Figure 37, Design 2, Tank \#21, Weld Line Fracture..................................................................6 63

Figure 38, Design 2, Tank \#20, After Burst Test......................................................................... 64

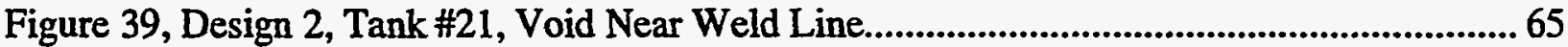

Figure 40, Design for SRIM Molding..........................................................................................65

Figure 41, Fabric Reinforced Thermoplastic Injection Molding................................................6 66

Figure 42, Lap Joint for Joining Tank Halves.................................................................................. 66

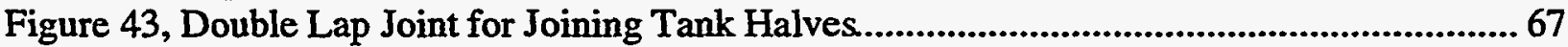

Figure 44, Butt Joint for Joining Tank Halves ......................................................................6 67 


\section{Introduction}

Liquefied petroleum gas (LPG) and compressed natural gas (CNG) are currently the leading fuel contenders for converting vehicles from gasoline and diesel to alternative fuels. Two factors that inhibit conversion are additional vehicle costs and reduced range compared to gasoline. In overcoming these barriers, a key element of the alternative fuel system becomes the storage tank for these pressurized fuels. Using cylindrical pressure vessels is the conventional approach, but - they do not package well in the available vehicle volume. Thiokol Corporation has developed and is now producing a conformable (non-cylindrical) aluminum storage system for LPG vans. This system increases fuel storage in a given rectangular envelope. The goal of this project was to develop the technology for a lower cost conformable tank made of injection-molded plastic.

Much of the cost of the aluminum conformable tank is in the fabrication because several weld seams are required. The injection-molding process has the potential to greatly reduce the fabrication costs. The whole tank could be molded to the final form in one piece, or a few molded parts could be assembled with a rapid thermoplastic welding process.

In designing an injection-molded tank, material selection becomes a major issue-a wide variety of materials is available. The requirements of a pressurized fuel tank on a vehicle necessitate the proper combination of material properties. Material selection and tank design must be optimized for maximum internal volume and minimum material use to be competitive with other technologies. The material and the design must also facilitate the injection-molding process.

Prototype tanks must be fabricated to reveal molding problems, prove solutions, and measure results. In production, efficient fabrication will be key to making these tanks cost competitive.

The work accomplished during this project has demonstrated that conformable LPG tanks can be molded with thermoplastics. However, to achieve a competitive tank, improvements are needed in the effective material strength. If these improvements can be made, molded plastics should produce a lower cost tank that can store more LPG on a vehicle than conventional cylinders.

\section{Project Information}

The U.S. Department of Energy, through the National Renewable Energy Laboratory (NREL), funded Thiokol Corporation to develop technology for using injection molding to produce lowcost conformable pressure tanks for vehicle fuel storage. The period of performance for this project was from March 1995 through December 1997, and this document is the project's final report.

\section{Conformable Storage Concept}

Pressurized tanks are typically cylindrical or spherical. These shapes produce membrane loading of the tank wall, which minimizes bending stresses and results in a strong, lightweight tank. When a pressurized tank must fit into a non-cylindrical space, as is usually the case in vehicles, cylindrical tanks waste much of the available space. As shown in Figure 1, a multi-cell tank concept provides more effective use of the available fuel storage volume. The cell geometry is carefully tailored to ensure efficient membrane loading of the cell walls under pressure loads, and 
the number of cells is optimized to provide maximum internal volume. Depending on the aspect ratio of the storage envelope, conformable tanks can provide as much as $40 \%$ more fuel volume than simple cylinders.

\section{Material Selection and Development}

\section{Material Properties}

Selection of an injection-molded thermoplastic for a pressurized fuel storage tank is complicated by the large number of available materials, and by how properties can vary depending on processing conditions. Published properties data are available for comparison, but the data may be inconsistent and incomplete. Because some of the key properties needed for pressurized tank design are not usually published, material selections must be made with incomplete data. Our laboratory tests at Thiokol have generated some of the missing data for the more promising materials.

For this application, tensile strength is the most important property. To achieve a competitive tank design, the effective tensile strength should exceed 18,000 pounds per square inch (psi). This strength requirement eliminates many materials, and narrows down the selection to "engineering" thermoplastics, which are typically reinforced with short glass fibers. Because the fibers tend to orient in the direction of molding flow, the strength of these plastics varies according to the direction of that flow-the highest strength is in the direction of flow, and lower strength is transverse to flow. In a pressure tank, where the entire tank is under tensile stress, the strength in the weakest direction will generally control the failure. Unfortunately, the transverse strength is not normally published. In the absence of data, the neat resin strength can be used as an estimate of the transverse strength of a reinforced plastic.

Another important property for automotive tanks is the fracture toughness, typically measured with the notched Izod test (ASTM D256). Tanks must be able to withstand mistreatment, such as pebble impacts and drops. The required toughness will depend on the tank wall thickness; a thicker wall will absorb more impact energy.

Because automotive service can cover a wide temperature range, temperature resistance is also important. The operating temperature may range from a low of $-40^{\circ} \mathrm{F}$ in extreme winter conditions to a high of $180^{\circ} \mathrm{F}$ in proximity to hot exhaust pipes during summer weather. The best published data related to temperature resistance are the deflection temperatures (ASTM D648), which must be substantially higher than $180^{\circ} \mathrm{F}$ for our application.

Long-term strength, as measured by the creep rupture test, is key, because LPG tanks must withstand sustained, continuous pressure for long periods of time. The creep rupture test measures the ability of a plastic to carry a sustained load for a long period of time. Thiokol performed high temperature $\left(180^{\circ} \mathrm{F}\right)$ creep rupture tests on two materials (AMODEL ${ }^{\otimes} \mathrm{A}-1115$ HS and AMODEL A-1133 HS) to determine the combined effects of sustained loading at high temperature.

Finally, resistance to attack by water, propane, and other chemicals is vital in the automotive environment. 


\section{Molded Bar Tests}

Most of the available material properties are from injection-molded tensile bars. Tensile properties were measured in the molding direction, providing only the upper limits for material strength. Table 1 is a compilation of data for several candidate materials. The first several lines are from published data sheets, and the Thiokol test results appear at the bottom of the table.

Our tensile test results at $75^{\circ} \mathrm{F}$ agree well with the manufacturer's data. We also measured strength at $180^{\circ} \mathrm{F}$. For most materials, this produced a moderate reduction in strength. One material, which in the initial screening appeared to have adequate strength, was severely weakened at $180^{\circ} \mathrm{F}$. The $\mathrm{RTP}^{\otimes} 2399 \times 68911 \mathrm{~A}$ polyurethane (PU) has a strength of $22,000 \mathrm{psi}$ at $75^{\circ} \mathrm{F}$, but only $4400 \mathrm{psi}$ at $180^{\circ} \mathrm{F}$. This was one of the higher toughness materials, but the low strength at high temperatures makes it unsuitable for use in a fuel tank.

For a few materials, Forward Technologies measured weld strength for Thiokol using a hot-plate welding process, which is a candidate for tank assembly. Injection-molded tensile bars were cut in half, then welded back together. Weldability is good for the AMODEL ${ }^{\circledR}$ polyphthalamide (PPA) materials. For the $33 \%$ glass-reinforced grade, which has a nominal tensile strength of $31.6 \mathrm{ksi}$, a weld strength of $14.7 \mathrm{ksi}$ was obtained (47\% of the original strength). With proper joint design, this would be adequate for tank welding. On the other hand, the Ryton ${ }^{\otimes}$ polyphenylene sulfide (PPS) achieved only $23 \%$ of its original strength when welded.

We measured the effects of exposure to LPG and CNG fuels by storing unstrained specimens in fuel for 40 days or longer and then measuring their tensile strength at $180^{\circ} \mathrm{F}$. The AMODEL PPA materials showed negligible changes in strength. The Ryton PPS showed about a 9\% strength reduction after exposure to LPG, and 15\% after CNG exposure. Other samples of these materials were exposed to fuel while under $0.5 \%$ strain; none of these showed any visible degradation.

We measured long-term strength by creep rupture tests at $180^{\circ} \mathrm{F}$ for two materials, and the results are plotted in Figure 2. At a creep time of 10,000 seconds, the AMODEL A-1133 material decreased to $74 \%$ of its short-term strength, and AMODEL A-1115 decreased to $80 \%$ of its short-term strength.

\section{Tube Burst Tests}

Using short tubes under internal pressure, we measured strength transverse to flow direction for several materials-three grades of Vectra ${ }^{\otimes}$ liquid crystal polymer (LCP), three grades of AMODEL PPA, two grades of RTP PPA, and one grade of Ryton PPS. Four samples were tested at $70^{\circ} \mathrm{F}$ for each material. For the Vectra materials, we also tested samples at $180^{\circ} \mathrm{F}$. The tubes were cut from injection-molded cylinders that have constant outer diameter, tapered wall thickness, and a hemispherical dome on one end. Plastic was injected at the center of the dome, resulting in axial flow in the cylinder. We used two variations of molded cylinders. Most of the samples were molded as $2.5 \mathrm{in}$. diameter by $4 \mathrm{in}$. long cylinders (see Figure 3). For one material (Vectra A130), the samples were made in a different mold, which was 2.12 in.diameter by 9 in. long. We molded these longer cylinders first, and discovered that they showed significant eccentricity of the core, which resulted in uneven wall thickness and unsymmetrical flow during molding. When we uncovered the asymmetry, we stopped using that mold.We prepared test samples by cutting the cylindrical portion of the molded parts into 4-in. lengths, discarding the 
dome. Each sample was tested by clamping it between two plates to seal the ends (see Figure 3), and pressurizing internally with water. O-rings provided a seal between the tube and the plates.

Table 2 shows sample measurements and test results. The strength was calculated as $\mathrm{P}^{*} \mathrm{r} / \mathrm{t}$, where $P$ is the burst pressure, $r$ is the outside radius, and $t$ is the minimum measured wall thickness.

Table 3 gives average strengths and their standard deviations, and Figure 4 illustrates the strength distributions.

The Vectra A950 material is formulated for extrusion rather than injection molding. Its unconventional flow characteristics caused it to mold poorly in our cylinders. Most of the parts had prominent knit lines that influenced the failures, resulting in huge variability in measured strength-from 2900 psi to 8400 psi at ambient temperature. In a surprising result from these tests, strength was generally higher at $180^{\circ} \mathrm{F}$, averaging $8500 \mathrm{psi}$.

The Vectra A1 15 material is reinforced with $15 \%$ glass, which results in higher and more consistent strength. At $70^{\circ} \mathrm{F}$, the average strength in these tubes was $17,300 \mathrm{psi}$, which is $62 \%$ of the handbook strength of $28,000 \mathrm{psi}$. The strength dropped to $9200 \mathrm{psi}$ at $180^{\circ} \mathrm{F}$.

Vectra A130 is reinforced with $30 \%$ glass. According to the published data sheets, this increase in reinforcement has no effect on the tensile strength, which remains at 28,000 psi. However, our tests showed a substantial reduction in the hoop strength of the tubes, to $6,300 \mathrm{psi}$. This might be partly because of the different molding configuration (the longer, smaller tube with significant eccentricity). Also, this test measures strength transverse to the molding flow, where the glass fiber reinforcement is not effective.

The AMODEL A-1133 HS (PPA with 33\% glass), RTP 4005 (PPA with 30\% glass), and Ryton $\mathrm{R}-4 \mathrm{XT}$ (PPS with 40\% glass) all showed similar strength and variability. AMODEL A-1145 HS (PPA with 45\% glass) and RTP 4001 (PPA with $10 \%$ glass) had about $25 \%$ less strength, but the variability was also much lower. AMODEL A-1115 HS (PPA with $15 \%$ glass) had the worst variability, with a coefficient of variation of $60 \%$.

\section{Dissected Tank Tests}

We molded one partial subscale tank from RTP 2399 X 68911 A (40\% glass reinforced PU). Two subscale tanks molded from AMODEL A-1133 HS (33\% glass reinforced PPA) were dissected for measurement of the material properties as molded in the conformable tank configuration. We cut samples from the cylinder walls and from the internal webs, then measured strengths in the axial direction (parallel to molding flow) and in the circumferential or transverse direction (perpendicular to molding flow). For the AMODEL tanks, strength was also measured across a major knit line. Because of the curvature in the cylinder, tensile samples were not possible in the circumferential direction, so we used flexure samples instead. We also tested flexure samples in the axial direction for comparison.

Table 4 gives the results of the PU tank dissect tests. Strength in the axial direction in the cylinder reaches $97 \%$ of the ideal strength based on molded tensile bars. Strength in the transverse direction in the interior web is only $27 \%$ of the ideal strength. The loss of strength at $180^{\circ} \mathrm{F}$ is excessive, which disqualifies this material as a candidate for the tanks.

Table 5 gives the results of the PPA tank dissect tests. Strength in the axial direction in the cylinder is only $75 \%$ of the ideal strength. Strength in the circumferential direction is $34 \%$ of the 
ideal strength. The strength of the knit line is approximately the same as the circumferential strength. Transverse strength in the web is somewhat higher, at $47 \%$ of ideal, possibly because of mixed flow directions in this region.

These dissected tank tests indicate that the effective strengths for reinforced plastics in the conformable tank configuration are only about $25 \%$ to $35 \%$ of the ideal strength. This is mainly because the anisotropic material properties tend to be oriented in the wrong directions. Good strength is achieved in the axial direction, but the highest stresses are in the circumferential direction, where strengths are very low. This problem might be corrected by designing the mold to fill in the circumferential direction. However, even with careful mold filling design, it is likely that there would be some regions where the flow orientation is poor, or where weld lines form, and failure would simply occur at the weakest location. A better option is to find or develop materials with adequate strength in the weakest direction.

\section{Primary Candidate Materials}

The two most promising materials identified are:

- AMODEL AS-1133 HS-a PPA, reinforced with 33\% glass. It was selected for excellent strength in the flow direction, moderate strength in the transverse direction, good hightemperature creep strength, excellent chemical resistance, good toughness, and moderate cost. It has the disadvantage of strong anisotropy caused by the glass reinforcement.

- FORTRON ${ }^{\circledR} 0214 \mathrm{Cl}$-a PPS, with no reinforcement. It was selected mainly because it was the strongest unreinforced material found. Its isotropic properties make it less sensitive to molding flow. It also has excellent chemical resistance and moderate cost. On the negative side, its toughness is low and mold shrinkage is high.

We used both these materials in the last set of subscale tanks molded.

\section{System Design}

\section{Design Requirements}

To ensure safety and acceptance, pressurized fuel tanks for vehicles are subject to strict design and verification requirements. Because the requirements for LPG containers are similar to those for CNG, we based our design on the CNG standards. However, some key differences between LPG and CNG do affect the tank requirements. Propane has a much lower vapor pressure than natural gas, and is stored as a liquid, rather than as a compressed gas, at the vapor pressure of the ambient temperature. Thus, the pressure does not vary as the tank is filled or drained, but does vary as the temperature changes, as shown in Figure 5. The service pressure for LPG is substantially lower than that for CNG.

Three levels of suggested requirements for LPG tanks are defined below.

- Design requirements give guidance in the design phase so the tank will meet functional needs and safely withstand service loads and exposure conditions. 
- Design verification and qualification tests are a series of specific tests that must be met by developmental tanks prior to going into production. They verify that the design actually meets its goals.

- Production verification is a set of tests that must be passed by each production tank or by tanks selected randomly from production runs. These tests ensure that production is under control, and that production of safe tanks continues.

During tank design, the requirements shown in Table 6 are used to guide the selection of materials, wall thicknesses, and other features of the tank design. They include the design envelopes, applied loads, service life, environmental conditions, and safety requirements.

The table provides two external envelopes. The subscale envelope is for a small tank for preliminary development. This envelope has been used for the tanks molded to date. The fullscale envelope is the Chrysler Ram van tank envelope for which aluminum tanks are currently being produced. This is a potential market for the plastic tanks, and serves as a good point of comparison between aluminum and plastic conformable tanks.

The internal volume of the tank must be maximized because the main rationale behind the conformable tank concept is to pack more fuel into the available space than is possible with cylindrical tanks. Cylindrical steel tanks can provide an internal volume of about $70 \%$ of a brickshaped external envelope, if multiple small cylinders are packed together. To be competitive, the conformable tanks should exceed this $70 \%$ volume efficiency.

The service pressure of $250 \mathrm{psig}$ corresponds to the vapor pressure of propane at $118^{\circ} \mathrm{F}$. Although the environmental temperature may locally reach $180^{\circ} \mathrm{F}$, the fuel temperature is not expected to exceed $118^{\circ} \mathrm{F}$. If it does, the peak pressure is controlled by a relief valve that allows venting to cool the fuel.

A design structural safety factor of 4.0 on ultimate strength provides leeway for variation of properties in the injection-molded plastic, and for small defects. In general, the 4.0 factor for ultimate strength will control, rather than the 2.0 factor for yield strength, because the yield strength is close to the ultimate strength for most high-strength plastics.

During a 15-year service life for the tank, the number of pressurization cycles is conservatively estimated at 18,000-more than three cycles per day for 15 years. For LPG tanks, these pressure cycles are driven by temperature changes rather than by filling and emptying.

\section{Design Verification and Qualification Tests}

To ensure that the tank design will meet functionality and safety requirements prior to going into production, Table 7 prescribes a rigorous series of tests. These requirements are based on References 1 through 3.

\section{Production Verification}

Once the tanks have gone into production, continuing tests are necessary to ensure that the manufacturing process remains under control and continues to produce safe tanks. These tests, based on Reference 1, include proof and leak tests on each individual tank, and cyclic and burst tests on each production lot of tanks, as described in Table 8. A production lot would be the tanks produced from a single lot of plastic during one production shift. 


\section{Subscale Tank Design and Analysis}

\section{Subscale Design 1}

Tank Design. The subscale tank is designed to fit an external envelope of $6 \times 10 \times 12$ in. Two internal structural webs divide it into three chambers. There are four external ports, two in each end of the tank, which open into the side chambers. Six holes in each web allow flow between the chambers. Figure 6 shows the general configuration of the subscale tank.

This tank uses $95.6 \mathrm{in}^{3}$, or $5.10 \mathrm{lb}$, of plastic. It has an internal volume of $479.3 \mathrm{in}^{3}$, or $2.07 \mathrm{gal}$. The volume efficiency is $66.6 \%$, comparing this internal volume to the volume of the $6 \times 10 \times 12$ in. external envelope. This is slightly below the target value of $70 \%$ volume efficiency.

The cylinder and web thicknesses were sized for a service pressure of $250 \mathrm{psi}$, a safety factor of 4.0 , and an effective material strength of $16,000 \mathrm{psi}$. However, detailed analysis (below) shows that a higher effective material strength is actually needed because of stress concentrations.

The external ports are reinforced by threaded metal bosses that are molded into the tanks. The internal holes in the webs are reinforced by flanges, which reduce the stress concentrations around the holes without having to thicken the entire web.

The external contours of the tank are formed by an aluminum injection mold. The internal contours are formed by a core assembly consisting of sand cores supported by steel rods that pass through the external ports of the tank. Spacing between the sand cores is maintained by tubular aluminum inserts, which also form the holes to allow fuel to flow through the webs between cells in the finished tank. The sand cores are formed from silica sand with a water-soluble binder. After injection molding, the steel rods are pulled out and the sand is washed away with water. The aluminum inserts remain in the finished tank.

Sand cores, which provide a lower cost method of molding small numbers of tanks, are planned for use only during tank development. During production, another method will be used to form hollow tanks. One option is a lost-core process that uses meltable metal cores. Another option is to mold a tank in separate parts that can be thermoplastically welded into a complete tank.

Finite Element Analysis. We performed several finite element analyses for the subscale tank design to ensure that it would meet the requirements. The different analyses included different levels of refinement and concentrated on different regions of the tank.

A shell element model of one-eighth of the tank was used to determine stresses in the cylinder and web walls, and to design the flanges that reinforce the web holes. The three planes of symmetry of the tank allow it to be modeled by this one-eighth model, shown in Figure 7.

We used the axisymmetric model in Figure 8 to analyze the region around the port, and to study the interaction between the metal boss and the surrounding plastic. The model shown here includes the redesigned metal boss, which we will discuss later. The axisymmetric analysis included contact elements between the boss and the plastic, and modeled the mold shrinkage of the plastic.

We used the plane strain cross section model in Figure 9 to analyze the junction between the cylinder walls and the interior webs. 
The three-dimensional solid model in Figure 10 models a symmetric section of the whole tank, including an accurate representation of the boss. However, it uses rather coarse elements, and does not model fillets and fine details. It accounts for the effects of wall thickness better than the shell model.

Table 9 summarizes analysis input properties. The plastic properties are typical values for a $30 \%$ to $40 \%$ glass-reinforced PPA. Properties are shown for both aluminum and steel because analyses were done for both the original aluminum boss as well as the later steel boss.

- Analysis results are summarized in Table 10. The highest stress shown is 6477 psi (at the operating pressure of $250 \mathrm{psi}$ ) in the web in the narrow gap between the flange of the small hole and the web/cylinder junction, based on the three-dimensional solid analysis. The second highest stress is near the same location, in the web/cylinder junction fillet, based on the cross section analysis. The three-dimensional solid analysis did include some higher stresses, but they were very localized and were not expected to cause tank failure.

Based on the finite element analyses, an effective material strength of 25,900 psi would be needed to achieve the required 4.0 safety factor.

Tanks were molded of AMODEL A-1133 HS material. They were then burst tested, tests that will be discussed in more detail later. The average burst pressure was 427 psi, with a standard deviation of 53 psi. Based on the finite element analysis, this indicates a nominal effective strength of 11,000 psi.

\section{Port Sealing}

When the first burst test was done (Tank 4), we observed leakage around the molded-in metal bosses. We saw leakage even before pressure was applied. The original design assumed that mold shrinkage of the plastic would cause it to squeeze onto the boss, providing a tight metal to plastic seal. Apparently, however, the plastic does not bond to the metal, and the interface provides a leak path.

Prior to testing the other three tanks, we designed a fitting that threaded into the molded-in bosses, and sealed with an O-ring against the plastic surface around the boss. Figure 11 shows the fitting design, and Figure 12 illustrates how it interfaces with the tank port.

We performed a finite element analysis of the fitting to determine how it would respond to changes in the temperature and pressure of the tank. The plot in Figure 13 shows how much the $\mathrm{O}$-ring gap opens as the tank is cooled. The maximum O-ring gap opening is $0.0012 \mathrm{in}$. at $-40^{\circ} \mathrm{F}$. This reduces the O-ring squeeze from $25 \%$ to $24 \%$, which is not enough to affect the seal.

This fitting worked well. We observed no leakage in any of the other three tanks, even after 15,000 pressure cycles on Tank 6 .

\section{Intermediate Design}

Keeping the following constraints and considerations in mind, we designed an intermediate subscale tank design.

- Keep stresses in plastic below 10,000 psi at the design burst pressure of 1000 psi. 
- Do not change any outer contours, which are controlled by the existing injection mold. New molds will be required for the internal cores.

- Facilitate manufacture by the metal lost-core process. Provide slope for complete drainage of core material, at least in the two side chambers.

- Assume no bonding between plastic and molded-in bosses. They must be retained by a mechanical lock only, and must be restrained against rotation.

Figure 14 shows the resulting subscale tank. All the walls are thicker to compensate for the lower material strength. The inner contour of the domes allows the side chambers to drain completely through the ports when the tank is vertical. The middle chamber still cannot be drained completely, but this is not vital in a subscale design that is used only for testing.

We reduced the number of holes in the webs and relocated them to reduce unnecessary stress concentrations and improve drainage. The four holes in each web are now located in the corners of the domes, where tensile stresses in the web are reduced by the bending of the dome under pressure. They are located as close as possible to the extremities of the web to allow nearly complete liquid drainage from one chamber to another.

The boss is retained against blowout loads by its flange. An undercut angle on the edge of the flange prevents the boss from being pushed into the tank. It is restrained against rotation by six holes that are filled with plastic.

This tank design uses $171.5 \mathrm{in}^{3}$ or $9.14 \mathrm{lb}$ of plastic and contains $403.0 \mathrm{in}^{3}$ or 1.74 gal of internal volume. This is $80 \%$ more plastic than the original subscale design, an increase that was necessary to accommodate lower material strength. The volume efficiency is reduced from $66.6 \%$ to $56.0 \%$, far below the target of $70 \%$. Improvements in the effective plastic strength will be necessary to achieve a competitive design.

We did not build any tanks to this intermediate design.

\section{Subscale Design 2}

Tank Design. We prepared the second complete subscale tank design with the goal of reaching a design burst pressure of 1000 psi with the worst expected material properties. The design strength is $7200 \mathrm{psi}$. This is a lower bound estimate of the strength of AMODEL A-1133 HS, as molded in the tank configuration. Based on the burst tests of subscale tank design 1, there was a $99 \%$ probability of the strength being greater than 7200 psi, as illustrated in Figure 15.

In redesigning the subscale tanks, the outer contour was kept the same, so no modifications of the injection mold were required. Because internal contours were changed in order to change the wall thicknesses and internal features, new molds for the sand cores had to be fabricated.

Figure 16 shows tank design 2. Wall thicknesses have increased to 0.57 in. in the cylinder, 0.53 in. in the internal webs, and 0.90 in. in the domes. The tank contains 265 in, or approximately 14 lb of plastic. The internal volume is $308 \mathrm{in}^{3}$, for a volume efficiency of $43 \%$. The holes through the webs have been relocated and reduced in number to reduce the stress concentrations. This should also improve flow during molding.

Finite Element Analysis. To arrive at this design, we conducted a series of finite element analyses. In these analyses, the cylinder thickness, web thickness, y-joint fillet radius, and web 
hole radius and location were adjusted to obtain a balanced design with maximum stresses below 7200 psi at 1000 psi pressure. Table 11 gives the results of each iteration.

These analyses used three-dimensional solid finite elements rather than shell elements, providing accurate results even in the junctions between the internal webs and the outer cylinders and domes. Stress contours at 1000 psi pressure for the final configuration are shown in Figures 17 and 18. The highest predicted stress is $7080 \mathrm{psi}$, somewhat lower than the target of $7200 \mathrm{psi}$, so the burst pressure was expected to exceed 1000 psi.

\section{Full-Scale Tank Design}

We designed a preliminary full-scale tank with the following constraints:

- Keep stresses in plastic below 10,000 psi at the design burst pressure of 1000 psi.

- Maximize tank volume in an envelope of $14 \times 24 \times 36$ in.

- Facilitate manufacture by the metal lost-core process. Provide slope for complete drainage of core material.

- Assume no bonding between plastic and molded-in bosses. They must be retained by a mechanical lock only, and must be restrained against rotation.

The result is shown in Figure 19. The design includes ports in both ends of all three chambers, providing improved support and alignment for the cores during injection molding, and facilitating complete drainage of the molten core material. After manufacture, the ports are designed to be closed by fittings that thread into the ports and seal with O-rings against the outer face of the plastic, similar to those used for the burst tests on the subscale tanks.

This tank design uses 2495 in $^{3}$ or $133 \mathrm{lb}$ of plastic and contains $7301 \mathrm{in}^{3}$ or 31.6 gal of internal volume. The volume efficiency is $60 \%$, low compared to the target of $70 \%$, but better than that of the intermediate subscale tank, which was designed with the same criteria.

\section{Cost Model}

We developed a cost model, implemented as an Excel spreadsheet, to estimate the relationship between material properties and tank cost, weight, and volume. The cost model includes strength criteria to hold internal pressure as well as toughness criteria to withstand external impact.

Thin wall membrane theory is used to estimate wall thicknesses for the webs, domes, and cylinders to hold the pressure. Transverse direction strength is the important material property for this criterion. For impact, closed form equations are used to approximate the cylinder wall deformation, stress, and strain under a point load, and to estimate the energy absorbed before cracking. This criterion accounts for yielding if the material is ductile. The important material properties for impact are the flow direction strength, modulus, and failure strain.

Using simplified tank geometry, the required wall thicknesses calculated from the strength and impact criteria are translated into material volume and internal volume. By comparing these calculations with the detailed design analyses of the subscale tanks, the calculations have been verified as reasonably accurate. 
The primary end results of the cost model are the internal volume, tank weight, and tank cost. The internal volume can be expressed in total gallons, or as a volume efficiency, which is the internal volume divided by the volume of the rectangular external envelope. With the volume, weight, and cost, it is still difficult to rank different tank materials, because a lower cost can compensate for some lost volume or increased weight. An overall grade parameter that combines these three values has been proposed, as volume divided by cost times weight. Thus, more volume, lower cost, or less weight result in a higher overall grade. The units of the overall grade are $\mathrm{in}^{3} / \$-\mathrm{lb}$.

Tables 12 through 14 give cost model calculations for an aluminum tank and for the two primary plastic candidates. These cost models are based on the best estimates of material properties after testing the first subscale tank design. As we will discuss, these properties were not achieved when the thicker second design was fabricated. Table 15 shows the cost model for a "target" material. This represents a hypothetical material custom developed for pressure tanks.

The results are compared in Figure 20. The volume efficiency of the plastic tanks is lower than the aluminum baseline. Because the plastics are not as strong as aluminum, thicker walls are necessary, which displaces some of the fuel volume. Likewise, the weight of the plastic tanks is higher, although the target material would approach the weight of an aluminum tank. The advantage of injection-molded tanks is in the cost, as the figure shows. The plastic tanks approach half the cost of an aluminum tank. With this cost advantage, plastic tanks have the potential of a higher overall grade than aluminum, also shown in Figure 20.

\section{System Fabrication}

\section{Subscale Design 1}

\section{First Molding Run}

Injection molding was done at Hettinga Equipment, in Des Moines, Iowa. In the first molding session, on January 24-25, 1996, we planned to mold with two candidate materials: RTP $2399 \mathrm{x}$ $68911 \mathrm{~A}$ (PU), and AMODEL A-1133 HS (PPA). However, because of molding problems, we used only the PU material.

A single set of aluminum cores was to be used for the initial molding, to set process parameters. This required cutting the plastic part into several pieces to remove the cores prior to molding the next part. The first part molded with the PU material was overfilled because of a miscalculation of shot size. This resulted in substantial flashing and thicker walls. The part filled completely, with no visible voids. It was much more difficult than expected to cut this tough plastic off of the mandrels. Rather than delaying the rest of the molding while cutting the plastic, we decided to go ahead with the sand cores. Only four sets of sand cores were available, and we planned to mold two with each material.

The first part made on a sand mandrel was only about $80 \%$ filled. However, much more serious than the partial filling was the fact that the sand cores were shifted and partially fractured by the injection pressure. As shown in Figure 21, injection was through a single gate at the center of one end of the part. Pressures at that end caused the cores to push toward the opposite end. The 
sand cores were supported by bearing against the metal bosses, but the sand in this area fractured, allowing the cores to push over the bosses until they contacted the end of the mold (see Figure 22). The connections between the three core sections were adequate. The three cores moved as a unit, failing only around the bosses.

We made three changes to try to correct the problem for the next injection attempt. The two downstream bosses were machined down to make room for heavy washers between the bosses and the sand cores to better support the cores. The injection gate diameter was increased to allow better flow into the mold. The melt and mold temperatures were increased to reduce viscosity. The shot size was also corrected to obtain complete filling. However, the changes were not sufficient. The cores again fractured at the polar bosses and shifted. The loads were high enough to permanently deform the washers.

For the third sand core assembly, we continued with the PU material. The downstream bosses were again modified, placing a stack of two heavy washers between the boss and the sand. Again, we increased the gate diameter. Runners were cut into the middle core to improve flow of plastic to the far end of the part. One runner was cut down the center of each web, approximately 0.37 in. wide by $0.19 \mathrm{in}$. deep. The mandrel again fractured and shifted.

With the fourth sand core assembly, we used double washers again, and cut larger runners into the center core. Two runners were cut on each web, approximately $0.5 \mathrm{in}$. wide by $0.19 \mathrm{in}$. deep. The end of the middle core was cut off to make an inlet chamber to help plastic reach the runners. As before, the mandrels fractured and shifted. However, with more plastic flow through the webs, the mandrels were also forced outward, which resulted in thick webs and thin outer walls.

This first molding session produced no complete tanks, but one of the partial tanks was dissected to obtain tensile strength samples as discussed earlier.

\section{Molding Process Changes}

After the first molding session, we made four changes to produce good parts in the second molding session.

We modified the injection mold to inject simultaneously at both ends of the tank, and added a second gate in the other end of the mold (see Figure 23). We also added a symmetrical runner system to bring plastic simultaneously to both ends of the tank.

We changed the sand binder formulation to provide higher strength at the mold temperature. The original formulation, with a PVA binder, has a strength of about $800 \mathrm{psi}$ at $300^{\circ} \mathrm{F}$. The new binder, with a sodium silicate binder, has a strength of about 4800 psi at $300^{\circ} \mathrm{F}$.

Because the original core surface was somewhat rough and quite porous, we added a smooth coating to the sand cores to reduce friction and improve plastic flow during injection.

Finally, we changed the boss design to provide better support to the sand cores. The new boss flares out to provide a 1.5 in. diameter bearing surface against the sand (Figure 24). To reduce deformation, the material was changed to steel. 


\section{Second Molding Run}

These molding process changes resulted in a successful second molding session on March 20-21, 1996. We prepared ten sets of sand cores for this session, and molded tanks from AMODEL A1133 HS. The changes solved the problem of the sand cores shifting during injection.

Photos of the mold are shown in Figures 25 through 28 . Figure 25 shows half the mold, prior to inserting the sand cores. Figure 26 shows the sand cores in the mold. They are supported by steel rods that are held in place by toggle clamps. Figure 27 shows the runner system, which provides balanced flow to the two ends of the mold. Figure 28 shows the molded part just after opening the mold. The weld line where the two flow fronts meet at the middle of the part is visible in this photo.

The first part was incompletely filled. We cut apart the second part to confirm that it filled completely. We used the same molding process parameters on the next seven parts. On the final part, higher injection rates and pressures were used, which produced a slightly smoother finish. Several of the parts had dark streaks, possibly caused by local overheating of the resin during injection. These streaks were most evident on the last part. Most of the parts also have some chalky surface areas on the domes, probably caused by local concentration of glass fibers. A knit line is clearly visible at the midplane, where the two main injection fronts meet. More complicated knit lines are visible on the internal webs, where plastic flows around the web holes and meets on several fronts.

Following molding, the tanks were annealed at $300^{\circ} \mathrm{F}$ for a minimum of 2 hours at the recommendation of Hettinga Equipment representatives.

After molding, Tanks 1 and 2 were cut up immediately to confirm complete interior filling. Tanks 3 and 7 were dissected for tensile bars, flexure bars, and impact tests. Tanks 4,8 , and 10 were burst tested. Tank 6 was pressure cycled and burst. Tanks 5 and 9 are being used for display.

\section{Subscale Design 2}

Starting on May 19, 1997, and finishing on May 22, 21 tanks of subscale design 2 were molded at Hettinga. Fourteen tanks were molded with AMODEL AS-1133 HS, and seven with FORTRON $0214 \mathrm{Cl}$. Table 16 gives the results of the molding, which encountered serious problems in the form of shrinkage cracks, voids, weak molding weld lines, and collapsed aluminum inserts.

The shrinkage cracks are a result of the plastic part being molded around and completely enclosing a rigid core. These cores are made of silica sand with a water-soluble sodium silicate binder. The sand cores are rigid and have low thermal expansion. Because the plastic shrinks significantly after molding, and the cores do not, large stresses built up in the plastic, resulting in cracks in many of the tanks. Shrinkage is accentuated by thicker sections, and did not cause apparent problems in the original tank design. In the first few tanks, the sand was washed out after the tanks had cooled, by immersing the whole tank in water and allowing the cores to soften gradually. In later tanks, the sand was washed out as soon as possible after molding in an attempt to allow the plastic to shrink more freely. Water was injected through a hose to soften and wash out the sand internally without cooling the plastic too rapidly. This process was only partly successful. Some tanks cracked before the sand could be washed out. Others cracked audibly during wash out. Others cracked several hours or more after wash out, although internal cracks 
were probably present earlier. Two of the FORTRON tanks that were shipped without cracks were found to have cracks after going through the annealing treatment.

The first tank molded was cut into quarters to check the internal filling. We found several voids near the main weld line, as shown in Figure 29. The largest voids are about 0.45 in. $x 0.27$ in. in size. After molding a few more tanks, the molders felt that the voids were caused because the runners were freezing off before the mold was completely packed. To allow better flow through the runners, the mold was pulled off of the machine, and the runners and sprues were increased in size. This mold modification was completed before molding Tank 8 . It did not completely solve the void problem.

Weak molding weld lines were apparent in many of the parts. Many of the shrinkage cracks occurred along the main weld line. Figure 30 shows an interesting flow pattern at the weld line in one of the FORTRON tanks. This looked like a potential weak spot, but the burst test fracture did not go through this spot. In some of the FORTRON tanks, glossy fracture surfaces were seen along the weld line, indicating a cold weld.

When some of the sand cores were being washed out, we could not get cross flow of water from one side cell to the other. The center cell was apparently sealed. We cut open one of these tanks (number 5), and found that the aluminum inserts that form the holes through the webs had crushed under the injection pressure. This problem was solved first by replacing the aluminum tubes with steel. Later we simply filled the aluminum tubes with loose sand to prevent them from collapsing.

\section{Fabrication Methods}

\section{Cup Welding}

The shrinkage problems encountered in molding the subscale tanks may have resulted from the part completely enclosing a rigid core. Molding the tank in halves would result in some freedom for axial shrinkage, reducing shrinkage problems. This would also simplify tank fabrication by eliminating the need to mold cores and remove them after molding the tank.

Some type of joining process would be required to assemble the tank halves, producing a hermetic and structural connection. Thermoplastic welding is one option. Initial trials have been done with this process.

Four materials were tested in a welded bottle configuration, as shown in Figure 31. Forward Technology Industries, Inc., made the welds using a hot plate process. The weld is at the thinnest wall section of the bottle, giving it a severe test. In most cases the bottles failed with a longitudinal crack, not along the circumferential weld. Table 17 summarizes the material strengths computed from the measured burst pressures.

Even though the failures did not follow the weld, the welded bottles were generally weaker than the monolithic tubes. For AMODEL A-1133 HS, the welded bottles were substantially weaker, as shown in Figure 32. For RTP 4005, the welded bottles approached the strength of the nonwelded tubes, as shown in Figure 33. If welded tank fabrication is found to be the best approach, a change in material would be necessary. 


\section{Process Improvement}

Our work has shown that the potential strength of the plastics is not being obtained in the molded tanks. Processing modifications that would improve the effective strength of the molded plastics are needed. We discussed this problem with an Amoco material engineer, who suggested that we contact TherMold Partners in Stamford, Connecticut, and investigate its vibrational molding technique.

\section{Vibrational Molding}

We held a meeting with representatives of TherMold Partners to investigate its vibrational molding technology, known as RHEOMOLDING ${ }^{\text {MM }}$. This technology has the potential to improve the effective material strength in our conformable tanks, making lighter, more competitive designs feasible. The potential is good enough that feasibility tests should be planned in the future.

Data published by TherMold shows significant strength increases (on the order of 20\%) for various unfilled materials with RHEOMOLDING. A dramatic strength increase of $111 \%$ was seen for a 45\%-glass-fiber-filled PPA molded with a weldline. An improvement in weldline strength is important in the conformable tanks because weldlines are formed as a result of flow around the boss inserts and web holes, as well as at the part midplane caused by injection from both ends. RHEOMOLDING also reduced the variability of strength, especially in samples with a weldline.

To date, TherMold has tested samples only in the direction of flow. Future feasibility tests should start with molding and testing transverse direction lab samples. If these samples show significant improvement in the transverse direction strength, the next step would be to test

RHEOMOLDING on the subscale tank. In the laboratory testing phase, a matrix of processing parameters would be run to identify the optimum conditions. Processing parameters include the frequency, amplitude, and duration of vibration. The sample thickness would also be varied to identify scale-up effects. Testing on subscale tanks would then require purchasing a limited license for the RHEOMOLDING technology, and installing the RHEOMOLDING equipment on a molding machine at Hettinga (or another molder).

\section{Experimental Program}

\section{Subscale Tank Design 1}

\section{Burst and Cyclic Pressure Tests}

Four tanks of design 1 were burst tested, and the results are given in Table 18. The average burst pressure for the four tanks was 427 psi. One tank (number 8 ) burst at a significantly lower pressure than the other three. Because of a data acquisition problem, the exact burst pressure was not recorded for this tank, but based on manual observation of the pressure gage and correlation with a strain gage, the burst pressure was about $350 \mathrm{psi}$.

Tank 10 was molded with higher injection rates and pressures than the other tanks. Although it had the highest burst pressure at $464 \mathrm{psi}$, the difference was not large enough to be significant. 
Tank 6 went through 15,000 pressure cycles, but still burst at 459 psi, indicating no degradation caused by pressure cycling.

It is not possible to identify for certain where failure initiated in these tanks. However, all four tanks have in common a failure along the junction between the internal web and the outer cylinder walls near the middle of the tank, as shown in Figure 34. This appears to be the most likely failure location. This location agrees with the location of maximum stresses in the finite element analyses. From this fracture, cracks propagate across the web and into the cylinder and dome regions. In this location, the stress at the average burst pressure of $427 \mathrm{psi}$ is 11,000 psi based on finite element analysis. This agrees very well with the circumferential direction strength, 10,700 psi, measured from dissected samples.

Although all these tanks have a prominent mid-length knit line because plastic was injected from both ends, in only one case does a fracture follow this knit line. On Tank 8, a crack runs axially the whole length of the tank on one side cylinder, and takes a lateral jog of about 2 in. along the knit line (see Figure 35). Similar axial cracks on the other tanks pass straight through the knit line. It appears that this knit line is normally not detrimental in these tanks. Indeed, the dissected samples show that the knit line has about the same strength as the transverse to flow direction in the material.

\section{Impact Tests}

We performed impact tests on Tanks 3 and 7, which were also the source for the dissect samples. Each tank was first cut in half longitudinally through the middle chamber. One half was reserved intact for impact testing; the other half was cut into lab samples.

Impact tests were done on a drop weight tester with a 0.5 in. diameter hemispherical impacter, instrumented to measure loads and energies. The half tank rested with the cut surface flat on a table, and the impacter struck it on the cylindrical part of the side chamber. Four impacts were made at different locations on each half-tank. Table 19 summarizes the available energy at impact, the energy absorbed by the tank, and observations of damage at the impact site.

The critical impact energy level for the subscale tank is about 5 foot-pounds ( $\mathrm{ft}-\mathrm{lb}$ ). If the available impact energy is below $5 \mathrm{ft}-\mathrm{lb}$, no damage is expected. Between 5 and $8 \mathrm{ft}-\mathrm{lb}$, local cracking is likely. Above $8 \mathrm{ft}-\mathrm{lb}$, the tank is likely to be pierced.

The full-scale tank needs to be able to withstand an impact of $22.1 \mathrm{ft}-\mathrm{lb}$, based on Reference 1 . The critical value for the subscale tank is well below this, indicating that impact is a significant design constraint. Scaling the tank up to full size will increase the critical value, but it may also be necessary to select a tougher material, possibly at the expense of some tensile strength.

\section{Subscale Tank Design 2}

\section{Burst Tests}

Burst tests were done for five tanks of subscale design 2: three AMODEL tanks and two FORTRON tanks. Results were given in Table 16. 
Burst test results for the AMODEL material were low and variable. In the original subscale tank design, with 0.19 in. thick cylinder walls, the average burst pressure for AMODEL was 427 psi. In the current design, with the wall thickness tripled to 0.57 in., the average burst pressure decreased to just $302 \mathrm{psi}$. The low burst pressures probably result from internal shrinkage damage. Failure modes were different in all three tanks. Tank 2 burst at 189 psi. It started leaking along the main weld line, but failed with a longitudinal split along one side. Tank 14 failed at $289 \mathrm{psi}$ with a local crack along the main weld. Tank 13 burst at 430 psi, breaking into two halves along the main weld line.

The FORTRON material produced much better results, but still below the 1000 psi target. The two tanks that could be burst tested failed at 643 and 839 psi, for an average of 741 psi. Failure modes were quite consistent. Both tanks fragmented into numerous pieces, with cracks radiating from the intersection between the main weld line and the web/cylinder y-joint (see Figure 36). We found voids in both tanks at this location. Tank 21 (with the higher burst pressure) had a poor weld line in this area, indicated by smooth, glossy internal surfaces (see Figure 37). Tank 20 did not have similar indications of a weak weld. It did have porosity (numerous small voids) in both domes (see Figure 38), although failure did not appear to begin there. One void near the weld line in Tank 21 had a darkened interior, as though it had been burned or contaminated (see Figure 39).

\section{Accomplishments}

In Phase I of the Low-Cost Conformable Storage project, we evaluated materials, designed a subscale tank, and fabricated and tested several copies of the tank. Tank burst pressures were lower than planned, and we found that the effective material strength as molded in the tank was much lower than expected. Based on the lower effective material strength, the subscale tank was redesigned, and a similar design was produced for a full-scale tank. It appears that these tanks would not be competitive because of the low volume efficiency and large amount of material required.

In Phase II, we redesigned the subscale tank in an attempt to reach the target burst pressure with conservative material properties. The target burst pressure was not achieved because the thicker walls caused processing problems. Most of the tanks developed obvious shrinkage cracks after molding, and the few tanks that could be burst tested failed at low pressures because of internal damage.

Phase II also encompassed a preliminary investigation of technologies that may help produce a viable tank. Thermoplastic welding was shown to be capable of producing a useful pressure vessel. Research into vibrational molding indicates a potential to improve as-molded material properties, but would need to be further explored with suitable tests.

The project did demonstrate, in one of the tanks, a burst pressure exceeding three times the operating pressure for LPG. It demonstrated the moldability of conformable pressure tanks, and also identified some concerns with the molding process. We developed a successful method to seal the ports, and tested it in a cyclic pressure test.

Based on this work, we now understand the limits of injection-molded plastics for pressure tanks better. Processing flow, weld lines, and shrinkage are important. The strength of reinforced plastics is highly anisotropic. Toughness and impact tolerance are an important design concern. 
Temperature sensitivity is significant, as plastics lose strength at high temperatures, and become brittle at low temperatures. Thermoplastics are injected at extremely high pressures, making it necessary to use very strong, rigid cores to form hollow cells. The injection-molding process can be difficult to scale up. Increases in wall thickness create higher shrinkage and increase cycle times by requiring longer cooling. Larger parts also require huge presses to contain the injection pressure.

\section{The Future}

Achieving traditional safety factors and light weight in plastic tanks requires an increase in the strength of the material. A likely way to increase the strength is to reinforce the material with fabric. This could be done in a structural reaction injection-molding (SRIM) process, or perhaps as a modification to thermoplastic injection molding. Another option is to pursue the development of higher strength thermoplastics.

\section{Structural Reaction Injection Molding}

The SRIM process is used commercially for producing large structural parts. It involves placing a reinforcement preform into a mold, and then injecting a thermoset resin into the mold. The resin has low viscosity and is injected at low pressure, typically less than 100 psi, allowing the use of less expensive mold tooling.

Figure 40 shows a concept for a SRIM conformable tank. This concept starts with rotationally molded liners to form the hollow cavities. Braided fiber reinforcement preforms would be placed over the liners, and the liners would be attached together, then placed into the mold for injection of the resin.

In this concept, the rotationally molded liners provide sealing for the fuel. The braided reinforcement carries most of the load, and the resin keeps the reinforcement in place.

This concept has several advantages. The existing subscale injection mold could be adapted for SRIM molding. The reinforcement provides the strength, reducing the requirements for the plastic. The liners form the cavities and seal the tank, so there are no cores to remove after molding. Tooling cost is relatively low for both rotational molds and SRIM molds, because they operate at low pressure. SRIM is suitable for scaling up to large parts.

One challenge is the joining and sealing of the separate cell liners. The liners need to be connected together with ports that allow fluid flow but are completely sealed. This can probably be done with a thermoplastic welding process.

\section{Higher Strength Thermoplastic Development}

Developing higher strength thermoplastics is a more challenging approach, but an important approach, because in the long run, it has the potential to produce the lowest cost tank. It would also have great benefit for many other applications that require higher strength thermoplastics.

Initial target material properties have already been defined and are listed in Table 20 . These targets would no doubt be refined as the program progressed. 
This development project would carry a high risk of failure and a relatively high expense. There is no guarantee that sufficient improvements could be made in the material properties. Numerous tanks would have to be molded to confirm progress, because plastics are very sensitive to the molding process.

\section{Fabric-Reinforced Thermoplastic Injection Molding}

The injection molder, Hettinga Technologies, has suggested incorporating fabric reinforcement in an injection-molded tank, a concept illustrated in Figure 41 . The tank would be molded in halves to reduce shrinkage problems and improve cycle times. Fabric reinforcement preforms would be placed into the mold prior to injection, and the plastic would flow into the reinforcement during injection. The tank halves would be joined by adhesive lap joints or thermoplastic welding. Various joining options are illustrated in Figures 42 through 44.

This approach has some advantages. The reinforcement provides the strength, so the thermoplastic resin could be selected for easy processing, good sealing, chemical resistance, toughness, and low cost. This approach also builds very directly on the injection-molding experience from this project.

There are also some challenges to this approach. It may be difficult to keep the reinforcement in place at the high injection pressures. Joining the tanks halves reliably will be a concern. New molds would probably be required for a development project, because the current mold is designed for monolithic tanks.

\section{Conclusions}

This project demonstrated the feasibility of conformable plastic pressure tanks, but also identified several difficulties. Several options are available to develop increased strength, which will make the conformable plastic tanks an attractive option.

\section{References}

1. "American National Standard for Basic Requirements for Compressed Natural Gas Vehicle (NGV) Fuel Containers, "ANSI/AGE NGV2-1992, August 6, 1992.

2. Federal Motor Vehicle Safety Standard (FMVSS) No. 304, Compressed Natural Gas Fuel Container Integrity, September 1994.

3. Supplemental Notice of Proposed Rulemaking (SNPRM), National Highway Traffic Safety Administration (NHTSA), Federal Register Excerpt 59 FR 65299 No. 242, December 19, 1994. 
Table 1, Material Properties Data

\begin{tabular}{|c|c|c|c|c|c|}
\hline Chemical Name & & $\begin{array}{c}\text { Polyphenylene } \\
\text { Sulfide }\end{array}$ & $\begin{array}{c}\text { Polyphenylene } \\
\text { Sulfide }\end{array}$ & $\begin{array}{c}\text { Polyphenylene } \\
\text { Sulfide }\end{array}$ & $\begin{array}{l}\text { Polyphenylene } \\
\text { Sulfide }\end{array}$ \\
\hline Commercial Name & & Ryton R-4XT & RTP 1301 & RTP 1305 & $\begin{array}{c}\text { FORTRON } 0205 \\
\text { P4 }\end{array}$ \\
\hline Manufacturer & & Phillips & RTP & RTP & $\begin{array}{l}\text { Hoechst } \\
\text { Celanese }\end{array}$ \\
\hline Filler & & Glass Fiber $40 \%$ & Glass Fiber $10 \%$ & Glass Fiber $30 \%$ & None \\
\hline Special Features & & $\begin{array}{c}\text { Dimensional stability } \\
\& \text { good moldability }\end{array}$ & \begin{tabular}{|c|}
$\begin{array}{c}\text { Flame retardant, } \\
\text { heat } \& \text { chemical } \\
\text { resistant }\end{array}$ \\
\end{tabular} & $\begin{array}{c}\text { Flame retardant, } \\
\text { heat \& chemical } \\
\text { resistant }\end{array}$ & high flow, low flash \\
\hline Processing Temp & ${ }^{\circ} \mathrm{F}$ & & 610 & 610 & 560 \\
\hline Mold Shrinkage, 1/8" & in/in & & 0.0060 & 0.0020 & 0.0120 \\
\hline Mold Shrinkage, 1/4" & in/in & & & & \\
\hline Melting Point & ${ }^{\circ} \mathrm{F}$ & & & & \\
\hline Density & $\mathrm{Ib} / \mathrm{ft} 3$ & 103.0 & 88.0 & 99.3 & 84.3 \\
\hline Tensile Str, Yield & lb/in2 & & 3.7E+3 & $17.0 E+3$ & $12.5 E+3$ \\
\hline Tensile Str, Break & Ib/in2 & $29.0 \mathrm{E}+3$ & & & $12.5 E+3$ \\
\hline Elongation, Yield & $\%$ & & & & \\
\hline Elongation, Break & $\%$ & 1.00 & & & 4.00 \\
\hline Tensile Modulus & lb/in2 & & $1.0 \mathrm{E}+6$ & $1.9 \mathrm{E}+6$ & \\
\hline Flexural Str, Yield & Ib/in2 & $41.0 \mathrm{E}+3$ & 12.0E+3 & $25.0 \mathrm{E}+3$ & $21.0 E+3$ \\
\hline Flexural Modulus & lb/in2 & $2.0 \mathrm{E}+6$ & $850.0 \mathrm{E}+3$ & $1.5 \mathrm{E}+6$ & $600.0 E+3$ \\
\hline Compressive Str & lb/in2 & $34.0 \mathrm{E}+3$ & $10.0 \mathrm{E}+3$ & $22.0 E+3$ & \\
\hline Izod, Notched, R.T. & $\mathrm{ft}-\mathrm{lb} / \mathrm{in}$ & 1.70 & 0.80 & 1.60 & 0.50 \\
\hline Linear Thermal Exp & in/in/ ${ }^{\circ} \mathrm{F}$ & & $20.0 \mathrm{E}-6$ & $14.0 \mathrm{E}-6$ & $23.0 \mathrm{E}-6$ \\
\hline Continuous Svc Temp & ${ }^{\circ} \mathrm{F}$ & & & & \\
\hline Defl Temp, 264 psi & ${ }^{\circ} \mathrm{F}$ & 500 & 450 & 500 & 221 \\
\hline Defl Temp, 66 psi & ${ }^{\circ} \mathrm{F}$ & & 500 & 500 & 390 \\
\hline Water Absorp, $24 \mathrm{hr}$ & $\%$ & & 0.0200 & 0.0200 & 0.0200 \\
\hline Cost & $\$ / 1 \mathrm{~b}$ & & & & 4.44 \\
\hline \multicolumn{6}{|l|}{ Thiokol Tests: } \\
\hline Tensile Stmgth, $75^{\circ} \mathrm{F}$ & lb/in2 & $27.0 E+3$ & & & \\
\hline Elongation, $75^{\circ} \mathrm{F}$ & $\%$ & 1.40 & & & \\
\hline Modulus, $75^{\circ} \mathrm{F}$ & lb/in2 & $2.30 E+6$ & & & \\
\hline Tensile Stmgth, $180^{\circ} \mathrm{F}$ & lb/in2 & $21.5 E+3$ & & & \\
\hline Elongation, $180^{\circ} \mathrm{F}$ & $\%$ & 1.52 & & & \\
\hline Modulus, $180^{\circ} \mathrm{F}$ & Ib/in2 & $2.21 E+6$ & & & \\
\hline Weld Strngth, $75^{\circ} \mathrm{F}$ & lb/in2 & $6.2 E+3$ & & & \\
\hline Weld \% of full strngth & $\%$ & 23 & & & \\
\hline Strength at $180^{\circ} \mathrm{F}$ after LPG & lb/in2 & $19.5 E+3$ & & & \\
\hline Strength at $180^{\circ} \mathrm{F}$ after CNG & Ib/in2 & $18.3 E+3$ & & & \\
\hline Aging in fuels with $.5 \%$ strain & & no damage & & & \\
\hline Creep Stmgth, $180^{\circ} \mathrm{F}, 10000 \mathrm{sec}$ & $\mathrm{lb} / \mathrm{in2}$ & & & & \\
\hline Hoop strength in tubes, $75^{\circ} \mathrm{F}$ & $\mathrm{lb} / \mathrm{in} 2$ & $13.4 E+3$ & & & \\
\hline Hoop strength in tubes, $180^{\circ} \mathrm{F}$ & Ib/in2 & & & & \\
\hline
\end{tabular}


Table 1, Material Properties Data (Continued)

\begin{tabular}{|c|c|c|c|c|c|}
\hline Chemical Name & & $\begin{array}{l}\text { Polyphenylene } \\
\text { Sulfide }\end{array}$ & $\begin{array}{l}\text { Polyphenylene } \\
\text { Sulfide }\end{array}$ & Polyphthalamide & Polyphthalamide \\
\hline Commercial Name & & \begin{tabular}{|c|} 
FORTRON 0214 \\
$\mathrm{C1}$
\end{tabular} & $\begin{array}{c}\text { FORTRON } 1140 \\
\text { L6 }\end{array}$ & $\begin{array}{l}\text { AMODEL } \\
\text { A-1115 HS }\end{array}$ & $\begin{array}{l}\text { AMODEL } \\
\text { A-1133 HS }\end{array}$ \\
\hline Manufacturer & & $\begin{array}{l}\text { Hoechst } \\
\text { Celanese }\end{array}$ & $\begin{array}{l}\text { Hoechst } \\
\text { Celanese }\end{array}$ & Amoco & Amoco \\
\hline Filler & & None & Glass $40 \%$ & Glass $15 \%$ & Glass $33 \%$ \\
\hline Special Features & & $\begin{array}{c}\text { Unreinforced, natura } \\
\text { color }\end{array}$ & & $\begin{array}{c}\text { Heat stabilized, low } \\
\text { moisture absorption } \\
\text { exc chem resist }\end{array}$ & $\begin{array}{l}\text { Heat stabilized, low } \\
\text { moisture absorption } \\
\text { exc chem resist }\end{array}$ \\
\hline Processing Temp & ${ }^{\circ} \mathrm{F}$ & 590 & 590 & 605 & 605 \\
\hline Mold Shrinkage, 1/8" & in/in & 0.0120 & 0.0020 & 0.0060 & 0.0020 \\
\hline Mold Shrinkage, 1/4" & in/in & & & & \\
\hline Melting Point & ${ }^{\circ} \mathrm{F}$ & & & 590 & 590 \\
\hline Density & $\mathrm{b} / \mathrm{b} / \mathrm{tt}$ & 84.3 & 102.0 & 78.6 & 89.3 \\
\hline Tensile Str, Yield & $\mathrm{Ib} / \mathrm{in} 2$ & $12.5 E+3$ & $29.0 E+3$ & & \\
\hline Tensile Str, Break & Ib/in2 & $12.5 \mathrm{E}+3$ & $29.0 E+3$ & $18.6 E+3$ & $32.0 \mathrm{E}+3$ \\
\hline Elongation, Yield & $\%$ & & & & \\
\hline Elongation, Break & $\%$ & 4.00 & 2.00 & 2.00 & 2.50 \\
\hline Tensile Modulus & $\mathrm{bb} / \mathrm{in} 2$ & & $2.1 \mathrm{E}+6$ & $1.2 \mathrm{E}+6$ & $1.9 \mathrm{E}+3$ \\
\hline Flexural Str, Yield & $\mathrm{bb} / \mathrm{in} 2$ & $21.0 E+3$ & $40.0 E+3$ & $24.8 E+3$ & $46.0 E+3$ \\
\hline Flexural Modulus & lb/in2 & $600.0 E+3$ & $2.0 \mathrm{E}+6$ & $900.0 \mathrm{E}+3$ & $1.7 \mathrm{E}+6$ \\
\hline Compressive Str & b/in2 & & & $30.0 \mathrm{E}+3$ & $40.0 E+3$ \\
\hline Izod, Notched, R.T. & $f t-1 b / i n$ & 0.50 & 1.90 & 0.80 & 2.10 \\
\hline Linear Thermal Exp & in/in/ ${ }^{\circ} \mathrm{F}$ & 259.0E-6 & $12.0 \mathrm{E}-6$ & $19.0 \mathrm{E}-6$ & 13.0E-6 \\
\hline Continuous Svc Temp & of F & & & 356 & 365 \\
\hline Defl Temp, 264 psi & ${ }^{\circ} \mathrm{F}$ & 221 & 500 & 531 & 545 \\
\hline Defl Temp, 66 psi & ${ }^{\circ} \mathrm{F}$ & 390 & 536 & 558 & 567 \\
\hline Water Absorp, $24 \mathrm{hr}$ & $\%$ & 0.0100 & 0.0200 & 0.3000 & 0.2100 \\
\hline Cost & $\$ 1 \mathrm{~b}$ & 5.65 & 3.52 & 2.75 & 2.75 \\
\hline \multicolumn{6}{|l|}{ Thiokol Tests: } \\
\hline Tensile Stmgth, $75^{\circ} \mathrm{F}$ & $\mathrm{b} / \mathrm{b} / \mathrm{in} 2$ & & & 17.7E+3 & $31.6 E+3$ \\
\hline Elongation, $75^{\circ} \mathrm{F}$ & $\%$ & & & 1.75 & 2.24 \\
\hline Modulus, $75^{\circ} \mathrm{F}$ & Ib/in2 & & & $1.07 E+6$ & $1.92 E+6$ \\
\hline Tensile Stmgth, $180^{\circ} \mathrm{F}$ & lib/in2 & & & $16.3 E+3$ & $25.9 E+3$ \\
\hline Elongation, $180^{\circ} \mathrm{F}$ & $\%$ & & & 1.90 & 2.59 \\
\hline Modulus, $180^{\circ} \mathrm{F}$ & Ib/in2 & & & $1.03 E+6$ & $1.77 \mathrm{E}+6$ \\
\hline Weld Strngth, $75^{\circ} \mathrm{F}$ & Ib/in2 & & & $11.3 E+3$ & 14.7E+3 \\
\hline Weld \% of full strngth & $\%$ & & & 64 & 47 \\
\hline Strength at $180^{\circ} \mathrm{F}$ after LPG & Ib/in2 & & & 16.0E+3 & $25.2 E+3$ \\
\hline Strength at $180^{\circ} \mathrm{F}$ after CNG & Ib/in2 & & & $16.0 \mathrm{E}+3$ & $24.9 E+3$ \\
\hline Aging in fuels with .5\% strain & & & & no damage & no damage \\
\hline Creep Stmgth, $180^{\circ} \mathrm{F}, 10000 \mathrm{sec}$ & Ib/in2 & & & $13.1 E+3$ & $19.1 E+3$ \\
\hline Hoop strength in tubes, $75^{\circ} \mathrm{F}$ & $\mathrm{Ib} / \mathrm{in} 2$ & & & $7.8 \mathrm{E}+3$ & 14.1E+3 \\
\hline Hoop strength in tubes, $180^{\circ} \mathrm{F}$ & lb/in2 & & & & \\
\hline
\end{tabular}


Table 1, Material Properties Data (Continued)

\begin{tabular}{|c|c|c|c|c|c|}
\hline Chemical Name & & Polyphthalamide & Polyphthalamide & Polyphthalamide & Polyphthalamide \\
\hline Commercial Name & & $\begin{array}{c}\text { AMODEL } \\
\text { AS-1133 HS }\end{array}$ & $\begin{array}{l}\text { AMODEL } \\
\text { A-1145 HS }\end{array}$ & RTP 4001 & RTP 4005 \\
\hline Manufacturer & & Amoco & Amoco & RTP & RTP \\
\hline Filler & & Glass $33 \%$ & Glass $45 \%$ & Glass Fiber $10 \%$ & Glass Fiber $30 \%$ \\
\hline Special Features & & $\begin{array}{c}\text { High heat def temp } \\
\text { modulus, stmgth, \& } \\
\text { creep resist,thick } \\
\text { walls }\end{array}$ & $\begin{array}{c}\text { Heat stabilized, low } \\
\text { moisture absorption } \\
\text { exc chem resist }\end{array}$ & $\begin{array}{l}\text { High strength \& stiff, } \\
\text { Heat defl temp, } \\
\text { thermal stability }\end{array}$ & $\begin{array}{l}\text { High strength \& stiff } \\
\text { Heat defl temp, } \\
\text { thermal stability }\end{array}$ \\
\hline Processing Temp & ${ }^{\circ} \mathrm{F}$ & 605 & 605 & & \\
\hline Mold Shrinkage, $1 / 8^{\prime \prime}$ & $\mathrm{in} / \mathrm{in}$ & 0.0040 & 0.0020 & & \\
\hline Mold Shrinkage, 1/4" & in/in & & & & \\
\hline Melting Point & ${ }^{\circ} \mathrm{F}$ & 590 & 590 & & \\
\hline Density & $\mathrm{ib} / \mathrm{ft} 3$ & 91.1 & 97.4 & 79.3 & 88.7 \\
\hline Tensile Str, Yield & ib/in2 & & & $13.5 E+3$ & $29.0 E+3$ \\
\hline Tensile Str, Break & lb/in2 & $32.0 \mathrm{E}+3$ & $37.5 E+3$ & & \\
\hline Elongation, Yield & $\%$ & & & 1.00 & 2.00 \\
\hline Elongation, Break & $\%$ & 2.50 & 2.60 & & \\
\hline Tensile Modulus & Ib/in2 & $1.9 E+6$ & $2.5 \mathrm{E}+3$ & $1.0 \mathrm{E}+6$ & $1.9 E+6$ \\
\hline Flexural Str, Yield & lb/in2 & $46.0 \mathrm{E}+3$ & $52.6 E+3$ & & \\
\hline Flexural Modulus & lb/in2 & $1.7 \mathrm{E}+6$ & $2.0 \mathrm{E}+6$ & $900.0 E+3$ & $1.6 \mathrm{E}+6$ \\
\hline Compressive Str & ib/in2 & $40.0 E+3$ & $45.5 E+3$ & & \\
\hline Izod, Notched, R.T. & $\mathrm{ft}-\mathrm{l} \mathrm{b} / \mathrm{in}$ & 2.10 & 2.50 & 0.60 & 1.80 \\
\hline Linear Thermal Exp & in/in/ ${ }^{\circ} F$ & $13.0 \mathrm{E}-6$ & $8.0 E-6$ & $21.0 \mathrm{E}-6$ & $13.0 \mathrm{E}-6$ \\
\hline Continuous Svc Temp & FF & 365 & 365 & & \\
\hline Defl Temp, 264 psi & ${ }^{\circ} \mathrm{F}$ & 545 & 549 & 420 & 530 \\
\hline Defl Temp, 66 psi & ${ }^{\circ} \mathrm{F}$ & 567 & 574 & & \\
\hline Water Absorp, $24 \mathrm{hr}$ & $\%$ & 0.2100 & 0.1200 & & \\
\hline Cost & $\$ / \mathrm{lb}$ & 2.85 & 2.75 & & \\
\hline \multicolumn{6}{|l|}{ Thiokol Tests: } \\
\hline Tensile Stmgth, $75^{\circ} \mathrm{F}$ & Ib/in2 & & $35.1 E+3$ & & \\
\hline Elongation, $75^{\circ} \mathrm{F}$ & $\%$ & & 2.53 & & \\
\hline Modulus, $75^{\circ} \mathrm{F}$ & $\mathrm{b} / \mathrm{b} / \mathrm{in} 2$ & & $2.23 E+6$ & & \\
\hline Tensile Stmgth, $180^{\circ} \mathrm{F}$ & ib/in2 & & $26.1 E+3$ & & \\
\hline Elongation, $180^{\circ} \mathrm{F}$ & $\%$ & & 3.23 & & \\
\hline Modulus, $180^{\circ} \mathrm{F}$ & Ib/in2 & & $1.89 E+6$ & & \\
\hline Weld Stmgth, $75^{\circ} \mathrm{F}$ & $\mathrm{b} / \mathrm{in} 2$ & & $14.5 E+3$ & & \\
\hline Weld \% of full strngth & $\%$ & & 41 & & \\
\hline Strength at $180^{\circ} \mathrm{F}$ after $\mathrm{LPG}$ & Ib/in2 & & $25.6 E+3$ & & \\
\hline Strength at $180^{\circ} \mathrm{F}$ after $\mathrm{CNG}$ & Ib/in2 & & $25.4 E+3$ & & \\
\hline Aging in fuels with .5\% strain & & & no damage & & \\
\hline Creep Stmgth, $180^{\circ} \mathrm{F}, 10000 \mathrm{sec}$ & Ib/in2 & & & & \\
\hline Hoop strength in tubes, $75^{\circ} \mathrm{F}$ & $\mid \mathrm{b} / \mathrm{in} 2$ & & $10.8 E+3$ & $11.2 E+3$ & $15.2 E+3$ \\
\hline Hoop strength in tubes, $180^{\circ} \mathrm{F}$ & |b/in2 & & & & \\
\hline
\end{tabular}


Table 1, Material Properties Data (Continued)

\begin{tabular}{|c|c|c|c|c|c|}
\hline Chemical Name & & Polyphthalamide & $\begin{array}{c}\text { Polyamide-Nylon } \\
6 / 6\end{array}$ & Polyurethane & Polyester (LCP) \\
\hline Commercial Name & & RTP 4007 & RTP 207H & $\begin{array}{c}\text { RTP } 2399 \mathrm{X} \\
68911 \mathrm{~A}\end{array}$ & Vectra A950 \\
\hline Manufacturer & & RTP & RTP & RTP & $\begin{array}{l}\text { Hoechst } \\
\text { Celanese }\end{array}$ \\
\hline Filler & & Glass Fiber $40 \%$ & Glass Fiber $40 \%$ & Glass Fiber $40 \%$ & \\
\hline Special Features & & \begin{tabular}{|c|} 
High strength \& stiff, \\
Heat defl temp, \\
thermal stability
\end{tabular} & High impact & $\begin{array}{l}\text { High impact, Low } \\
\text { water absorption }\end{array}$ & $\begin{array}{l}\text { Not for injection } \\
\text { molding }\end{array}$ \\
\hline Processing Temp & ${ }^{\circ} \mathrm{F}$ & & 550 & 500 & 545 \\
\hline Mold Shrinkage, 1/8" & in/in & 0.0020 & 0.0010 & 0.0010 & 0.0020 \\
\hline Mold Shrinkage, $1 / 4^{*}$ & in/in & 0.0030 & 0.0030 & 0.0020 & \\
\hline Melting Point & ${ }^{\circ} \mathrm{F}$ & & & & 536 \\
\hline Density & Ib/ft3 & 95.5 & 88.0 & 94.0 & \\
\hline Tensile Str, Yield & $\mathrm{lb} / \mathrm{in} 2$ & $30.0 E+3$ & $21.0 E+3$ & $27.0 \mathrm{E}+3$ & $24.0 \mathrm{E}+3$ \\
\hline Tensile Str, Break & $\mathrm{lb} / \mathrm{in2}$ & & & & $24.0 \mathrm{E}+3$ \\
\hline Elongation, Yield & $\%$ & 2.00 & 3.30 & 2.40 & \\
\hline Elongation, Break & $\%$ & & & & 3.00 \\
\hline Tensile Modulus & ib/in2 & $2.2 E+6$ & $1.6 \mathrm{E}+6$ & $1.8 \mathrm{E}+6$ & $1.4 \mathrm{E}+6$ \\
\hline Flexural Str, Yield & Ib/in2 & $40.0 E+3$ & $32.0 E+3$ & $65.0 E+3$ & $24.5 E+3$ \\
\hline Flexural Modulus & Ib/in2 & $2.0 \mathrm{E}+6$ & $1.2 \mathrm{E}+6$ & $1.3 \mathrm{E}+6$ & $1.3 E+6$ \\
\hline Compressive Str & lb/in2 & & $23.8 E+3$ & & \\
\hline Izod, Notched, R.T. & $f t-1 b / i n$ & 2.00 & 4.00 & 8.00 & 10.00 \\
\hline Linear Thermal Exp & in/in/ $F$ & $10.0 \mathrm{E}-6$ & $9.0 \mathrm{E}-6$ & & \\
\hline Continuous Svc Temp & ${ }^{\circ} \mathrm{F}$ & & & & \\
\hline Defl Temp, 264 psi & ${ }^{\circ} \mathrm{F}$ & 535 & 480 & 200 & 356 \\
\hline Defl Temp, 66 psi & ${ }^{\circ} \mathrm{F}$ & & 495 & & \\
\hline Water Absorp, $24 \mathrm{hr}$ & $\%$ & 0.2000 & 0.6000 & 0.0140 & 0.0000 \\
\hline Cost & $\$ 1 \mathrm{~b}$ & & 3.19 & & \\
\hline \multicolumn{6}{|l|}{ Thiokol Tests: } \\
\hline Tensile Stmgth, $75^{\circ} \mathrm{F}$ & Ib/in2 & $31.4 \mathrm{E}+3$ & $23.4 E+3$ & $22.1 E+3$ & \\
\hline Elongation, $75^{\circ} \mathrm{F}$ & $\%$ & 2.01 & 3.12 & 2.00 & \\
\hline Modulus, $75^{\circ} \mathrm{F}$ & Ib/in2 & $2.02 E+6$ & $1.38 \mathrm{E}+6$ & $1.40 \mathrm{E}+6$ & \\
\hline Tensile Strngth, $180^{\circ} \mathrm{F}$ & Ib/in2 & $24.5 E+3$ & $14.4 \mathrm{E}+3$ & $4.4 \mathrm{E}+3$ & \\
\hline Elongation, $180^{\circ} \mathrm{F}$ & $\%$ & 2.48 & 6.61 & 5.77 & \\
\hline Modulus, $180^{\circ} \mathrm{F}$ & $\mathrm{lb} / \mathrm{in2}$ & $1.90 E+6$ & $620.00 E+3$ & $253.00 \mathrm{E}+3$ & \\
\hline Weld Stmgth, $75^{\circ} \mathrm{F}$ & lb/in2 & & & & \\
\hline Weld \% of full strngth & $\%$ & & & & \\
\hline Strength at $180^{\circ} \mathrm{F}$ after LPG & ib/in2 & & & & \\
\hline Strength at $180^{\circ} \mathrm{F}$ after $\mathrm{CNG}$ & lb/in2 & & & & \\
\hline \multicolumn{6}{|l|}{ Aging in fuels with .5\% strain } \\
\hline Creep Stmgth, $180^{\circ} \mathrm{F}, 10000 \mathrm{sec}$ & Ib/in2 & & & & \\
\hline Hoop strength in tubes, $75^{\circ} \mathrm{F}$ & $\mathrm{b} / \mathrm{in} 2$ & & & & $5.0 \mathrm{E}+3$ \\
\hline Hoop strength in tubes, $180^{\circ} \mathrm{F}$ & $\mathrm{ib} / \mathrm{in} 2$ & & & & $8.5 E+3$ \\
\hline
\end{tabular}


Table 1, Material Properties Data (Continued)

\begin{tabular}{|c|c|c|c|c|c|}
\hline Chemical Name & & Polyester (LCP) & Polyester (LCP) & Polyester (LCP) & Polyester (LCP) \\
\hline Commercial Name & & Vectra A115 & Vectra A130 & Xydar G-540 & Xydar G-930 \\
\hline Manufacturer & & $\begin{array}{l}\text { Hoechst } \\
\text { Celanese }\end{array}$ & $\begin{array}{l}\text { Hoechst } \\
\text { Celanese }\end{array}$ & Amoco & Amoco \\
\hline Filler & & Chop Glass $15 \%$ & Chop Glass $30 \%$ & Glass & Glass \\
\hline Special Features & & very easy flow & & $\begin{array}{l}\text { high strength, } \\
\text { processability \& } \\
\text { flame res. }\end{array}$ & \\
\hline Processing Temp & ${ }^{\circ} \mathrm{F}$ & 520 & 545 & 620 & \\
\hline Mold Shrinkage, 1/8" & in/in & & 0.0010 & & \\
\hline Mold Shrinkage, 1/4" & in/in & & & & \\
\hline Melting Point & ${ }^{\circ} \mathrm{F}$ & 536 & 535 & 590 & 610 \\
\hline Density & lb/tt3 & & 99.9 & 106.0 & 99.8 \\
\hline Tensile Str, Yield & $\mathrm{lb} / \mathrm{in} 2$ & $28.0 E+3$ & $30.0 E+3$ & & \\
\hline Tensile Str, Break & ib/in2 & $28.0 E+3$ & $30.0 \mathrm{E}+3$ & $21.2 E+3$ & 19.6E+3 \\
\hline Elongation, Yield & $\%$ & & & & \\
\hline Elongation, Break & $\%$ & 3.00 & 2.00 & 1.50 & 1.60 \\
\hline Tensile Modulus & b/in2 & $1.9 E+6$ & $2.4 E+6$ & $2.9 E+6$ & $2.7 E+6$ \\
\hline Flexural Str, Yield & b/in2 & $30.0 E+3$ & $37.0 \mathrm{E}+3$ & $27.0 \mathrm{E}+3$ & $25.0 E+3$ \\
\hline Flexural Modulus & lb/in2 & $1.6 E+6$ & $2.1 \mathrm{E}+6$ & $2.3 E+6$ & $2.0 \mathrm{E}+6$ \\
\hline Compressive Str & lb/in2 & & & & \\
\hline Izod, Notched, R.T. & ft-lb/in & 5.50 & 2.80 & 8.30 & 1.80 \\
\hline Linear Thermal Exp & $\mathrm{in} / \mathrm{in} /{ }^{\circ} \mathrm{F}$ & & $2.8 E-6$ & 7.0E-6 & 7.0E-6 \\
\hline Continuous Svc Temp & ${ }^{\circ} \mathrm{F}$ & & & & \\
\hline Defl Temp, 264 psi & ${ }^{\circ} \mathrm{F}$ & 417 & 446 & 466 & 520 \\
\hline Defl Temp, 66 psi & $\circ F$ & & & & \\
\hline Water Absorp, $24 \mathrm{hr}$ & $\%$ & 0.0000 & 0.0100 & & \\
\hline Cost & $\$ s / b$ & 11.60 & 9.00 & 6.95 & 7.30 \\
\hline \multicolumn{6}{|l|}{ Thiokol Tests: } \\
\hline Tensile Stmgth, $75^{\circ} \mathrm{F}$ & $\mathrm{lb} / \mathrm{in} 2$ & & & & \\
\hline Elongation, $75^{\circ} \mathrm{F}$ & $\%$ & & & & \\
\hline Modulus, $75^{\circ} \mathrm{F}$ & Ib/in2 & & & & \\
\hline Tensile Stmgth, $180^{\circ} \mathrm{F}$ & to/in2 & & & & \\
\hline Elongation, $180^{\circ} \mathrm{F}$ & $\%$ & & & & \\
\hline Modulus, $180^{\circ} \mathrm{F}$ & $\mathrm{b} / \mathrm{in2}$ & & & & \\
\hline Weld Stmgth, $75^{\circ} \mathrm{F}$ & lb/in2 & & & & \\
\hline Weld $\%$ of full strngth & $\%$ & & & & \\
\hline Strength at $180^{\circ} \mathrm{F}$ after $\mathrm{LPG}$ & ib/in2 & & & & \\
\hline Strength at $180^{\circ} \mathrm{F}$ after CNG & ib/in2 & & & & \\
\hline \multicolumn{6}{|l|}{ Aging in fuels with $.5 \%$ strain } \\
\hline Creep Stmgth, $180^{\circ} \mathrm{F}, 10000 \mathrm{sec}$ & bib/in2 & & & & \\
\hline Hoop strength in tubes, $75^{\circ} \mathrm{F}$ & lb/in2 & $17.3 E+3$ & $6.3 E+3$ & & \\
\hline Hoop strength in tubes, $180^{\circ} \mathrm{F}$ & lb/in2 & $9.2 \mathrm{E}+3$ & $4.6 \mathrm{E}+3$ & & \\
\hline
\end{tabular}




\section{THIOKOLL}

AEROSPACE \& INDUSTRLAL TECHNOLOGIES

Table 1, Material Properties Data (Continued)

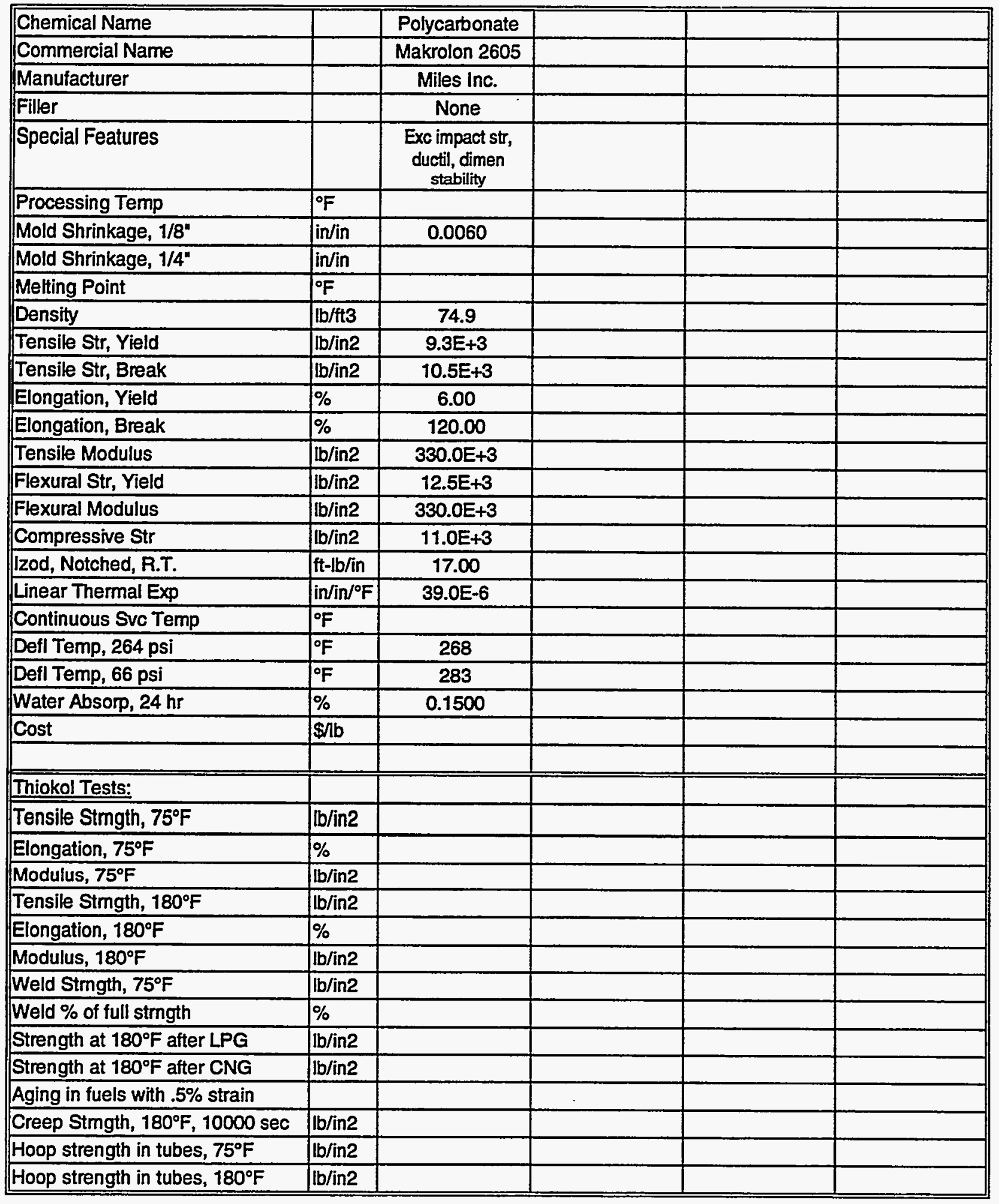


Table 2, Tube Burst Data

\begin{tabular}{|c|c|c|c|c|c|c|c|c|c|c|}
\hline \multirow{3}{*}{$\begin{array}{l}\text { Cominercial } \\
\text { Name }\end{array}$} & \multirow{3}{*}{$\begin{array}{l}\text { Specimen } \\
\text { Number }\end{array}$} & \multirow{3}{*}{$\begin{array}{c}\text { O.D. } \\
\text { (in) }\end{array}$} & \multicolumn{4}{|c|}{ Thickness } & \multirow{3}{*}{$\begin{array}{l}\text { Temp. } \\
\left({ }^{\circ} \mathrm{F}\right)\end{array}$} & \multirow{3}{*}{\begin{tabular}{|c|} 
Burst \\
Pressure \\
(psi)
\end{tabular}} & \multirow{3}{*}{$\begin{array}{l}\text { Strength } \\
\text { (psi) }\end{array}$} & \multirow{3}{*}{\begin{tabular}{|l} 
average \\
$\&$ std dev. \\
(psi)
\end{tabular}} \\
\hline & & & \multicolumn{2}{|c|}{ End A } & \multicolumn{2}{|c|}{ End $B$} & & & & \\
\hline & & & Max & Min & $\operatorname{Max}$ & Min & & & & \\
\hline Vectra A950 & A9501 & 2.50 & 0.131 & 0.128 & 0.210 & 0.204 & 70 & 862.40 & 8422 & 5036 \\
\hline Vectra A950 & A950 2 & 2.50 & 0.131 & 0.129 & 0.226 & 0.205 & 70 & 555.99 & 5388 & 2494 \\
\hline Vectra A950 & A950 3 & 2.50 & 0.132 & 0.126 & 0.219 & 0.205 & 70 & 342.13 & 3394 & \\
\hline Vectra A950 & A950 4 & 2.50 & 0.131 & 0.123 & 0.218 & 0.202 & 70 & 289.52 & 2942 & \\
\hline Vectra A950 & A950 5 & 2.50 & 0.131 & 0.127 & 0.218 & 0.204 & 180 & 995.55 & 9799 & 8531 \\
\hline Vectra A950 & A950 6 & 2.50 & 0.131 & 0.127 & 0.218 & 0.204 & 180 & 641.28 & 6312 & 1767 \\
\hline Vectra A950 & A950 7 & 2.50 & 0.131 & 0.127 & 0.218 & 0.204 & 180 & 804.35 & 7917 & \\
\hline Vectra A950 & A950 8 & 2.50 & 0.131 & 0.127 & 0.218 & 0.204 & 180 & 1026.00 & 10098 & \\
\hline Vectra A115 & A115 39 & 2.50 & 0.128 & 0.124 & 0.215 & 0.204 & 70 & 1726.60 & 17405 & 17346 \\
\hline Vectra A115 & A1 1540 & 2.50 & 0.126 & 0.123 & 0.214 & 0.204 & 70 & 1727.60 & 17557 & 284 \\
\hline Vectra A115 & A115 11 & 2.50 & 0.127 & 0.124 & 0.214 & 0.204 & 70 & 1679.50 & 16930 & \\
\hline Vectra A115 & A115 12 & 2.50 & 0.128 & 0.124 & 0.214 & 0.205 & 70 & 1735.30 & 17493 & \\
\hline Vectra A115 & A115 41 & 2.50 & 0.126 & 0.123 & 0.214 & 0.205 & 180 & 934.79 & 9500 & 9176 \\
\hline Vectra A115 & 11542 & 2.50 & 0.127 & 0.123 & 0.214 & 0.204 & 180 & 894.59 & 9091 & 247 \\
\hline Vectra A115 & A1159 & 2.50 & 0.127 & 0.124 & 0.215 & 0.205 & 180 & 912.61 & 9200 & \\
\hline Vectra A115 & A115 10 & 2.50 & 0.129 & 0.124 & 0.215 & 0.205 & 180 & 884.01 & 8911 & \\
\hline Vectra A130 & A1302-a & 2.12 & 0.141 & 0.119 & 0.179 & 0.135 & 70 & 510.48 & 4547 & 6314 \\
\hline Vectra A130 & A130 2-b & 2.12 & 0.179 & 0.136 & 0.206 & 0.148 & 70 & 928.68 & 7238 & 1342 \\
\hline Vectra A130 & A130 7-8-a & 2.12 & 0.132 & 0.123 & 0.162 & 0.144 & 70 & 696.38 & 6001 & \\
\hline Vectra A130 & A130 7-8-b & 2.12 & 0.166 & 0.147 & 0.194 & 0.162 & 70 & 1035.70 & 7468 & \\
\hline Vectra A130 & A130 7-4-a & 2.12 & 0.138 & 0.122 & 0.161 & 0.143 & 180 & 500.56 & 4349 & 4553 \\
\hline Vectra A130 & A130 7-4-b & 2.12 & 0.167 & 0.147 & 0.192 & 0.162 & 180 & 673.75 & 4858 & 354 \\
\hline Vectra A130 & A130 7-10-a & 2.12 & 0.131 & 0.124 & 0.161 & 0.143 & 180 & 486.41 & 4158 & \\
\hline Vectra A130 & $A 1307-10-b$ & 2.12 & 0.167 & 0.146 & 0.192 & 0.161 & 180 & 667.49 & 4846 & \\
\hline AMODEL A-1115 HS & $1115-1$ & 2.50 & 0.132 & 0.123 & 0.220 & 0.214 & 70 & 611.00 & 6209 & 7819 \\
\hline AMODEL A-1115 HS & $1115-6$ & 2.50 & 0.133 & 0.126 & 0.221 & 0.198 & 70 & 1331.00 & 13204 & 4667 \\
\hline AMODEL A-1115 HS & $1115-27$ & 2.50 & 0.132 & 0.126 & 0.223 & 0.211 & 70 & 734.00 & 7282 & \\
\hline AMODEL A-1115 HS & $1115-18$ & 2.50 & 0.132 & 0.126 & 0.223 & 0.213 & 70 & 1129.00 & 11200 & \\
\hline AMODEL A-1115 HS & $1115-15$ & 2.50 & 0.142 & 0.128 & 0.228 & 0.219 & 70 & 123.00 & 1201 & \\
\hline AMODEL A-1133 HS & $1133-32$ & 2.50 & 0.137 & 0.127 & 0.228 & 0.215 & 70 & 1538.00 & 15138 & 14095 \\
\hline AMODEL A-1133 HS & $1133-24$ & 2.50 & 0.135 & 0.128 & 0.220 & 0.213 & 70 & 1728.00 & 16875 & 2523 \\
\hline AMODEL A-1133 HS & $1133-26$ & 2.50 & 0.134 & 0.127 & 0.226 & 0.214 & 70 & 1114.00 & 10965 & \\
\hline AMODEL A-1133 HS & $1133-29$ & 2.50 & 0.134 & 0.126 & 0.218 & 0213 & 70 & 1351.00 & 13403 & \\
\hline AMODEL A-1145 HS & $1145-37$ & 2.50 & 0.136 & 0.129 & 0.221 & 0.213 & 70 & 1329.00 & 12878 & $\overline{10817}$ \\
\hline AMODEL A-1145 HS & $1145-36$ & 2.50 & 0.136 & 0.129 & 0.220 & 0.213 & 70 & 1147.00 & 11114 & 1336 \\
\hline AMODEL A-1145 HS & $1145-2$ & 2.50 & 0.133 & 0.126 & 0.222 & 0.213 & 70 & 931.00 & 9236 & \\
\hline AMODEL A-1145 HS & $1145-3$ & 2.50 & 0.132 & 0.125 & 0.221 & 0.213 & 70 & 1044.00 & 10440 & \\
\hline AMODEL A-1145 HS & $1145-4$ & 2.50 & 0.134 & 0.126 & 0.222 & 0.216 & 70 & 1050.00 & 10417 & \\
\hline RTP 4001 & $4001-4$ & 2.50 & 0.131 & 0.126 & 0.218 & 0.210 & 70 & 1032.00 & 10238 & 11210 \\
\hline RTP 4001 & $4001-6$ & 2.50 & 0.131 & 0.124 & 0.220 & 0.210 & 70 & 1014.00 & 10222 & \\
\hline RTP 4001 & $4001-42$ & 2.50 & 0.135 & 0.127 & 0.216 & 0.208 & 70 & 1167.00 & 11486 & \\
\hline RTP 4001 & $4001-63$ & 2.50 & 0.134 & 0.126 & 0.219 & 0.211 & 70 & 1149.00 & 11399 & \\
\hline RTP 4001 & $4001-64$ & 2.50 & 0.133 & 0.127 & 0.221 & 0.210 & 70 & 1291.00 & 12707 & \\
\hline RTP 4005 & $4005-4005$ & 2.50 & 0.136 & 0.127 & 0.218 & 0.208 & 70 & 1372.00 & 13504 & 15224 \\
\hline RTP 4005 & $4005-$ & 2.50 & 0.133 & 0.126 & 0.217 & 0.204 & 70 & 1200.00 & 11905 & 23 \\
\hline RTP 4005 & $4005-19$ & 2.50 & 0.135 & 0.129 & 0.226 & 0.216 & 70 & 1736.00 & 16822 & \\
\hline RTP 4005 & $4005-8$ & 2.50 & 0.132 & 0.126 & 0.219 & 0.209 & 70 & 1704.00 & 16905 & \\
\hline RTP 4005 & 4005-3 & 2.50 & 0.136 & 0.129 & 0.222 & 0.213 & 70 & 1753.00 & 16986 & \\
\hline Ryton & Ryton 41 & 2.50 & 0.136 & 0.127 & 0.224 & 0.214 & 70 & 1666.00 & 16398 & 13391 \\
\hline Ryton & Ryton 37 & 2.50 & 0.120 & 0.110 & 0.212 & 0.200 & 70 & 1341.00 & 15239 & 23 \\
\hline Ryton & Ryton 18 & 2.50 & 0.136 & 0.126 & 0.227 & 0.213 & 70 & 1255.00 & 12450 & \\
\hline Ryton & Ryton 9 & 2.50 & 0.134 & 0.127 & 0.225 & 0.216 & 70 & 1121.00 & 11033 & \\
\hline Ryton & Ryton 3 & 2.50 & 0.135 & 0.128 & 0.225 & 0.216 & 70 & 1212.00 & 11836 & \\
\hline
\end{tabular}


Table 3, Tube Burst Summary

\begin{tabular}{|c|c|c|c|c|c|c|}
\hline & \multicolumn{3}{|c|}{$70^{\circ} \mathrm{F}$} & \multicolumn{3}{|c|}{$180^{\circ} \mathrm{F}$} \\
\hline Material & $\begin{array}{c}\text { Mean } \\
(p s i)\end{array}$ & $\begin{array}{l}\text { Std } \\
\text { Dev } \\
\text { (psi) }\end{array}$ & $\bar{N}$ & $\begin{array}{c}\text { Mean } \\
\text { (psi) }\end{array}$ & $\begin{array}{l}\text { Std } \\
\text { Dev } \\
\text { (psi) }\end{array}$ & $N$ \\
\hline Vectra A950 & 5036 & 2494 & 4 & 8531 & 1767 & 4 \\
\hline Vectra A115 & 17346 & 284 & 4 & 9176 & 247 & 4 \\
\hline Vectra A130 & 6314 & 1342 & 4 & 4553 & 354 & 4 \\
\hline AMODEL A-1115 HS & 7819 & 4667 & 5 & & & \\
\hline AMODEL A-1133 HS & 14095 & 2523 & 4 & & & \\
\hline AMODEL A-1145 HS & 10817 & 1336 & 5. & & & \\
\hline RTP 4001 & 11210 & 1034 & 5 & & & \\
\hline RTP 4005 & 15224 & 2370 & 5 & & & \\
\hline Byton & 13391 & 2308 & 5 & & & \\
\hline
\end{tabular}

Table 4, Tank Dissect, RTP2399 x 68911 A Polyurethane, Tensile Bars

\begin{tabular}{|l|c|c|}
\hline & $75^{\circ} \mathrm{F}$ & $180^{\circ} \mathrm{F}$ \\
\hline \hline Molded Bars & 22,100 & 4,400 \\
\hline Dissected Tank & \multicolumn{2}{|l|}{} \\
\hline Cylinder & 21,400 & 11,500 \\
\hline Inner Web & 6,000 & 2,500 \\
\hline
\end{tabular}

Table 5, Tank Dissect, AMODEL A-1133 HS Polyphthalamide

\begin{tabular}{||l||c|c||c|c||}
\hline \multicolumn{1}{||l||}{} & \multicolumn{2}{c||}{$75^{\circ} \mathrm{F}$} & \multicolumn{2}{c|}{$180^{\circ} \mathrm{F}}$. \\
\cline { 2 - 5 } & $\begin{array}{c}\text { Tensile } \\
\text { Strength } \\
\text { (psi) }\end{array}$ & $\begin{array}{c}\text { Flexure } \\
\text { Strength } \\
\text { (psi) }\end{array}$ & $\begin{array}{c}\text { Tensile } \\
\text { Strength } \\
\text { (psi) }\end{array}$ & $\begin{array}{c}\text { Flexure } \\
\text { Strength } \\
\text { (psi) }\end{array}$ \\
\hline \hline Molded Bars & 31,600 & & 25,900 & \\
\hline Dissected Tanks & 23,800 & 42,300 & 22,000 & 41,800 \\
\hline Cylinder Axial & $10,700^{*}$ & 19,000 & $13,300^{*}$ & 25,300 \\
\hline Cylinder Hoop & 11,100 & & 11,300 & \\
\hline Knit Line Axial & $11,900^{*}$ & 21,100 & $11,100^{*}$ & 21,100 \\
\hline Knit Line Hoop & 14,700 & & 12,100 & \\
\hline Web Transverse & & &
\end{tabular}

* Estimated from flexure strength 
Table 6, Tank Design Requirements

\begin{tabular}{|c|c|c|}
\hline Condition & Requirements & Comments \\
\hline \multicolumn{3}{|l|}{ Tank Design } \\
\hline $\begin{array}{l}\text { External Envelope } \\
\text { Subscale } \\
\text { Full-Scale } \\
\end{array}$ & $\begin{array}{l}12^{\prime \prime} \times 10^{\prime \prime} \times 6 " \\
36^{\prime \prime} \times 24^{\prime \prime} \times 14^{\prime \prime} \\
\end{array}$ & \\
\hline Internal Volume & $>70 \%$ of external envelope & \\
\hline Fuel & LPG & \\
\hline \multicolumn{3}{|l|}{ Loading } \\
\hline Service Pressure & 250 psig & Nominal internal pressure \\
\hline $\begin{array}{l}\text { Structural Factor } \\
\text { of Safety }\end{array}$ & $\begin{array}{l}4.0 \text { on ultimate } \\
2.0 \text { on yield } \\
\end{array}$ & Burst test verification \\
\hline Dynamic Loads & $\begin{array}{l}30 \mathrm{mph} \text { vehicle crash } \\
20 \mathrm{ft} \text { empty tank drop }\end{array}$ & \\
\hline \multicolumn{3}{|l|}{ Service Life } \\
\hline Tank Life & 15 years & $\begin{array}{l}\text { Includes } 15,000 \text { cycles to service pressure } \\
\text { plus } 3,000 \text { to } 1.25 \text { x service pressure }\end{array}$ \\
\hline \multicolumn{3}{|l|}{ Environmental Conditions } \\
\hline Temperature & $-40^{\circ} \mathrm{F}$ to $180^{\circ} \mathrm{F}$ & . \\
\hline Humidity & $0 \%$ to $100 \%$ & \\
\hline $\begin{array}{l}\text { Vehicle, road, and } \\
\text { other fluids }\end{array}$ & $\begin{array}{l}\text { Salt spray } \\
\text { Engine oil } \\
\text { Antifreeze } \\
\text { Battery acid } \\
\text { Brake fluid } \\
\text { Propane and constituents } \\
\text { Other chemicals }\end{array}$ & $\begin{array}{l}\text { "Identification of Service Environment of } \\
\text { NGV Fuel Cylinders", July 1994, Gas } \\
\text { Research Institute }\end{array}$ \\
\hline $\begin{array}{l}\text { Impact and } \\
\text { Abrasion }\end{array}$ & $\begin{array}{l}\text { Rock and gravel impact } \\
\text { and scrapes }\end{array}$ & Pendulum impact and flaw tolerance tests \\
\hline \multicolumn{3}{|l|}{ Safety } \\
\hline Fire & \multirow{2}{*}{\multicolumn{2}{|c|}{ No fragmentation of tank when subjected to fire or puncture }} \\
\hline Puncture & & \\
\hline
\end{tabular}


Table 7, Design Verification and Qualification Tests

\begin{tabular}{|c|c|c|}
\hline & Description & Purpose \\
\hline 1. & $\begin{array}{l}\text { Burst Test. Three tanks. The tank is filled with water, pressurized to } 2.25 \\
\text { times the service pressure, and held for ten seconds. Pressure is then increased } \\
\text { to rupture. The pressurization rate is not to exceed } 200 \text { psi/second. }\end{array}$ & $\begin{array}{l}\text { Verifies the tank's ability to } \\
\text { withstand the pressure of the } \\
\text { fuel. }\end{array}$ \\
\hline 2. & $\begin{array}{l}\text { Pressure Cycles. Three tanks. The tank is filled with water and subjected to } \\
13,000 \text { cycles from } 10 \% \text { to } 100 \% \text { of service pressure, followed by } 5,000 \text { cycles } \\
\text { from } 10 \% \text { to } 125 \% \text { of service pressure. The frequency is not to exceed } 10 \\
\text { cycles/minute. The tank is required to experience no leakage. }\end{array}$ & $\begin{array}{l}\text { Verifies the tank's ability to } \\
\text { withstand cyclic pressure } \\
\text { loads caused by temperature } \\
\text { variation over a } 15 \text {-year } \\
\text { service life. }\end{array}$ \\
\hline 3. & $\begin{array}{l}\text { Environmental Cycles. One tank. The tank is filled with a mixture of water, } \\
\text { hydrogen sulfide, carbon dioxide, and propane. It is held at } 140^{\circ} \mathrm{F} \text { for } 30 \text { days. } \\
\text { It is then drained at held for } 48 \text { hours unpressurized at } 140^{\circ} \mathrm{F} \text { and } 95 \% \text { relative } \\
\text { humidity. Then, while at } 140^{\circ} \mathrm{F} \text {, it is subjected to } 5,000 \text { pressure cycles } \\
\text { between } 10 \% \text { and } 125 \% \text { of service pressure. Next, it is subjected to } 5,000 \\
\text { pressure cycles between } 10 \% \text { and } 100 \% \text { of service pressure at a temperature of } \\
-40^{\circ} \mathrm{F} \text {. The tank is required to experience no leakage nor permanent } \\
\text { deformation. }\end{array}$ & $\begin{array}{l}\text { Evaluates the tank's } \\
\text { resistance to internal } \\
\text { corrosion, high humidity, } \\
\text { and high and low } \\
\text { temperatures. }\end{array}$ \\
\hline 4. & $\begin{array}{l}\text { Salt Spray Test. One tank. The tank is subjected to a salt spray for } 240 \text { hours. } \\
\text { It is then subjected to } 5,000 \text { cycles between } 10 \% \text { and } 125 \% \text { of service pressure } \\
\text { at ambient temperature and humidity, followed by } 5,000 \text { cycles between } 10 \% \\
\text { and } 100 \% \text { of service pressure at }-40^{\circ} \mathrm{F} \text {. The tank is required to experience no } \\
\text { leakage nor permanent deformation. }\end{array}$ & $\begin{array}{l}\text { Evaluates the tank's } \\
\text { resistance to road salt. }\end{array}$ \\
\hline 5. & $\begin{array}{l}\text { Flaw Tolerance. One tank. A longitudinal flaw is cut near mid-length on the } \\
\text { tank, } 1.0^{n} \text { long by } 0.030^{n} \text { deep. The tank is subjected to } 1,500 \text { pressure cycles } \\
\text { from } 10 \% \text { to } 100 \% \text { of service pressure. The tank is required to experience no } \\
\text { flaw propagation. Pressurize to burst and record burst pressure. }\end{array}$ & $\begin{array}{l}\text { Evaluates the tank's } \\
\text { resistance to external } \\
\text { abrasion. }\end{array}$ \\
\hline 6. & $\begin{array}{l}\text { Pendulum Impact. One tank. The empty container is struck by an impacter } \\
\text { with a kinetic energy of } 22.1 \mathrm{ft}-\mathrm{lb} \text {, at a temperature of } 70^{\circ} \mathrm{F} \text {. The impacter is to } \\
\text { be in the shape of a pyramid with a square base and four equilateral pyramid } \\
\text { sides. The edges and tip are to be rounded with a } 0.12^{\prime \prime} \text { radius. The mass of } \\
\text { the impacter is to be } 33 \text { lbs. After impact, the tank is subjected to } 1,500 \text { cycles } \\
\text { from } 10 \% \text { to } 100 \% \text { of service pressure, and is required to experience no } \\
\text { leakage. }\end{array}$ & $\begin{array}{l}\text { Evaluates the tank's ability } \\
\text { to withstand a sharp external } \\
\text { impact, such as a rock strike. }\end{array}$ \\
\hline 7. & $\begin{array}{l}\text { Drop Test. One tank. The empty, unpressurized tank is dropped } 10 \text { feet in a } \\
\text { horizontal orientation onto a smooth concrete floor. If damage is visible the } \\
\text { tank must still withstand } 1,500 \text { pressure cycles from } 10 \% \text { to } 100 \% \text { of service } \\
\text { pressure without leakage. If no damage is visible the tank must then withstand } \\
5,000 \text { cycles from } 10 \% \text { to } 125 \% \text { of service pressure followed by } 13,000 \text { cycles } \\
\text { from } 10 \% \text { to } 100 \% \text { of service pressure without leakage. }\end{array}$ & $\begin{array}{l}\text { Evaluates the tank's ability } \\
\text { to withstand a blunt external } \\
\text { impact. }\end{array}$ \\
\hline 8. & $\begin{array}{l}\text { Bonfire Test. One tank. The tank is filled with LPG and suspended above a } \\
\text { fuel fire. The tank is required to vent to zero pressure without rupturing. }\end{array}$ & $\begin{array}{l}\text { Evaluates the tank's ability } \\
\text { to safely vent when exposed } \\
\text { to fire. }\end{array}$ \\
\hline 9. & $\begin{array}{l}\text { High Temperature Creep. One tank. The tank is filled with water and } \\
\text { pressurized to } 125 \% \text { of service pressure at a temperature of } 180^{\circ} \mathrm{F} \text {, and held } \\
\text { for } 200 \text { hours. It is then returned to } 70^{\circ} \mathrm{F} \text { and pressurized to } 1.5 \text { times service } \\
\text { pressure, and held for at least } 30 \text { seconds. The tank is drained and pressurized } \\
\text { with dry air and inspected for leaks. Then it is refilled with water and } \\
\text { subjected to } 5,000 \text { cycles from } 10 \% \text { to } 125 \% \text { of service pressure. No leakage } \\
\text { nor permanent deformation is allowed. }\end{array}$ & $\begin{array}{l}\text { Evaluates the tank's ability } \\
\text { to withstand high } \\
\text { temperatures. }\end{array}$ \\
\hline 10. & $\begin{array}{l}\text { Gunfire. One tank. The tank is pressurized to service pressure with air or } \\
\text { nitrogen. It is impacted by a } 0.30 \text { caliber amor piercing projectile at } \\
\text { approximately } 2800 \text { feet/second at an angle of approximately } 45^{\circ} \text { to the } \\
\text { cylinder wall. The container is required to not fragment. }\end{array}$ & $\begin{array}{l}\text { Evaluates the tank's ability } \\
\text { to withstand a puncture } \\
\text { without catastrophic failure. }\end{array}$ \\
\hline 11. & $\begin{array}{l}\text { Permeation. One tank. Permeation of propane through the tank wall is } \\
\text { measured at service pressure. It must not exceed } 0.25 \mathrm{cc} \text { per hour per liter of } \\
\text { intermal volume. }\end{array}$ & $\begin{array}{l}\text { Evaluates the permeability } \\
\text { of the tank for fuel. }\end{array}$ \\
\hline
\end{tabular}


Table 8, Production Verification Tests

\begin{tabular}{|l|l|}
\hline 1. & $\begin{array}{l}\text { Proof Test. Every production tank will be pressurized to } 150 \% \text { of the service pressure and } \\
\text { held for at least } 30 \text { seconds. Permanent volume expansion during this test is not to exceed } \\
5 \% \text { of the total expansion. }\end{array}$ \\
\hline 2. & $\begin{array}{l}\text { Leak Test. Every production tank will be leak tested at service pressure with dry air. Weld } \\
\text { seams and other joints will be examined for leakage. }\end{array}$ \\
\hline 3. & $\begin{array}{l}\text { Cyclic Pressure Test. One tank from each lot will be subjected to 5,000 cycles from } 10 \% \text { to } \\
125 \% \text { of service pressure, at a frequency not to exceed } 10 \text { cycles per minute. No leakage } \\
\text { nor failure is allowed. The tank is to be destroyed after the test. }\end{array}$ \\
\hline 4. & $\begin{array}{l}\text { Burst Test. One tank from each lot will be subjected to a burst test. This may be the same } \\
\text { tank that went through the cyclic pressure test. The tank will be pressurized to } 2.25 \text { times } \\
\text { the service pressure, held for ten seconds, and then pressurized to failure. The } \\
\text { pressurization rate is not to exceed } 200 \text { psi/second. }\end{array}$ \\
\hline
\end{tabular}

Table 9, Analysis Input Properties

\begin{tabular}{|l||c|c|c|}
\hline \multicolumn{1}{|c||}{ Property } & Plastic & Aluminum & Steel \\
\hline \hline Modulus (psi) & $1.9 \mathrm{E} 6$ & $1.0 \mathrm{E} 7$ & $2.9 \mathrm{E} 7$ \\
\hline Poisson's ratio & 0.41 & 0.3 & 0.3 \\
\hline Coeff. of Thermal Exp. (in/in/\%) & $3.3 \mathrm{E}-5$ & $1.3 \mathrm{E}-5$ & $6.5 \mathrm{E}-6$ \\
\hline Mold shrinkage (in/in) & $2.0 \mathrm{E}-3$ & & \\
\hline
\end{tabular}


Table 10, Finite Element Analysis Results, Original Subscale Design

\begin{tabular}{||l|c|}
\hline \multicolumn{1}{|c|}{ Location } & $\begin{array}{c}\text { Stress (psi) at Service } \\
\text { Pressure of 250 psi }\end{array}$ \\
\hline \hline Shell Analysis & 4830 \\
\hline Cylinder & 4740 \\
\hline Web & 3720 \\
\hline Small hole flange & 3870 \\
\hline Large hole flange & 5696 \\
\hline Dome & \\
\hline Axisymmetric Analysis & 5325 \\
\hline Around Boss & \\
\hline Cross Section Analysis & 3843 \\
\hline Cylinder & 3750 \\
\hline Web & 5765 \\
\hline Junction fillet & \\
\hline 3-D Solid Analysis & 4515 \\
\hline Cylinder & 3900 \\
\hline Mid web & 6477 \\
\hline Web between small hole and web/cyl junction & 4874 \\
\hline Small hole flange & 4242 \\
\hline Large hole flange & 5540 \\
\hline Dome & \\
\hline
\end{tabular}

Table 11, Analysis Iterations for Second Subscale Design

\begin{tabular}{|c|c|c|c|c|c|c|c|c|c|}
\hline & & & & \multicolumn{3}{|c|}{ Web Hole } & \multicolumn{3}{|c|}{ Stresses } \\
\hline $\begin{array}{c}\text { Model } \\
\text { Name }\end{array}$ & $\begin{array}{c}\text { Cylinder } \\
\text { Thickness }\end{array}$ & $\begin{array}{c}\text { Web } \\
\text { Thickness }\end{array}$ & $\begin{array}{c}\text { Fillet } \\
\text { Radius }\end{array}$ & Radius & $\begin{array}{c}\text { Y- } \\
\text { coord }\end{array}$ & $\begin{array}{c}Z \\
\text { coord }\end{array}$ & $\begin{array}{c}\text { Y-joint } \\
\text { Hole } \\
\text { inner } \\
\text { edge }\end{array}$ & $\begin{array}{c}\text { Hole } \\
\text { outer } \\
\text { edge }\end{array}$ \\
\hline sub2_solid & 0.500 & 0.350 & 0.300 & 0.625 & 1.600 & 3.800 & 7920 & 8940 & 9220 \\
\hline sub3_solid & 0.500 & 0.450 & 0.400 & 0.625 & 1.500 & 3.750 & 7920 & 8200 & 7340 \\
\hline sub4_solid & 0.500 & 0.450 & 0.500 & 0.625 & 1.600 & 3.800 & 7980 & 7640 & 7670 \\
\hline sub5_solid & 0.550 & 0.450 & 0.500 & 0.625 & 1.500 & 3.750 & 7050 & 7620 & 7550 \\
\hline sub6_solid & 0.550 & 0.500 & 0.500 & 0.500 & 1.600 & 3.900 & 7250 & 7340 & 6750 \\
\hline sub7_solid & 0.570 & 0.530 & 0.400 & 0.500 & 1.600 & 3.900 & 7080 & 6930 & 6530 \\
\hline
\end{tabular}


Table 12, Cost Model for Aluminum Tank

\begin{tabular}{|c|c|c|}
\hline \multicolumn{3}{|c|}{6061 Aluminum } \\
\hline \multicolumn{3}{|c|}{ Full Size Conformable } \\
\hline & Value & Source or Description \\
\hline \multicolumn{3}{|r|}{ Inputs } \\
\hline \multicolumn{3}{|l|}{ Material Properties } \\
\hline Density (lb/in3) & 0.1000 & \\
\hline$M+1$ Cost $(S / b)$ & 2.60 & \\
\hline TD Tens Strength (psi) & 38000 & \\
\hline FD Flex Strength (psi) & 38000 & \\
\hline FD Flex Modulus (psi) & $10.0 E+6$ & \\
\hline FD Fail Strain (in/in) & 0.0040 & \\
\hline Poisson's Ratio & 0.30 & \\
\hline \multicolumn{3}{|l|}{ Fabrication } \\
\hline \begin{tabular}{|l|l} 
& Fab Cost (\$/tank) \\
\end{tabular} & 1000.00 & Estimate \\
\hline \multicolumn{3}{|l|}{ Requirements } \\
\hline Burst Pressure (psi) & 1000 & $4 \times$ operating pressure \\
\hline Impact (in-Ibs) & 0 & pendulum impact \\
\hline \multicolumn{3}{|l|}{ Design Geometry } \\
\hline \begin{tabular}{|l|l|} 
& Conformable? \\
\end{tabular} & 1 & $1=$ conformable, $0=$ cylinders \\
\hline Wh (in) & 24.00 & Tank Width \\
\hline Wv (in) & 14.00 & Tank Thickness \\
\hline$L$ (in) & 36.00 & Tank Length \\
\hline Nh (integer) & 3 & Number of cells across width \\
\hline Nv (integer) & 1 & Number of cells through thickness \\
\hline b/r (ratio) & 0.5000 & Dome height/radius ratio \\
\hline $\mathrm{Ch} / \mathrm{r}$ (ratio) & 0.7143 & Cell width/radius, optimize for max inside vol. \\
\hline \multicolumn{3}{|c|}{ Calculations } \\
\hline Cv/r (ratio) & - & Cell thickness/radius \\
\hline$r$ (in) & 7.0000 & Cell wall radius \\
\hline Ch (in) & 5.0000 & Cell width \\
\hline Cv (in) & - & Cell thickness \\
\hline ti (in) & 0.0000 & thickness of outer wall for ductile impact \\
\hline ts (in) & 0.1842 & thickness of outer wall for strength \\
\hline tr (in) & 0.1842 & thickness of outer wall \\
\hline th (in) & - & thickness of horizontal webs \\
\hline to (in) & 0.1316 & thickness of vertical webs \\
\hline $\mathrm{tD}$ (in) & 0.3684 & thickness of domes \\
\hline theta $h$ (rad) & - & \\
\hline theta $v$ (rad) & 1.2056 & \\
\hline At (in2) & 290.90 & Total cross section area of tank profile \\
\hline Ap (in2) & 15.31 & Cross section area of walls \\
\hline Sd (in2) & 775.74 & Approximate surface area of domes \\
\hline Vd (in3) & 1357.54 & Approximate volume of domes \\
\hline Vt (in3) & 9793.70 & Total external volume of tank \\
\hline \multicolumn{3}{|c|}{ Outputs } \\
\hline$V_{p}$ (in3) & 729.81 & Total volume of tank walls and domes \\
\hline Vi (in3) & 9063.90 & Internal volume \\
\hline gallons (gal) & 39.24 & Internal volume \\
\hline Veff (\%) & $74.93 \%$ & Volume efficiency \\
\hline weight (bs) & 72.98 & Empty tank weight \\
\hline material cost (\$) & 189.75 & \\
\hline total cost (\$) & 1189.75 & \\
\hline V/SW (in3/s-1b) & 0.10439 & Combined Performance \\
\hline
\end{tabular}


Table 13, Cost Model for AMODEL AS-1133 HS Tank

\begin{tabular}{|c|c|c|}
\hline \multicolumn{3}{|c|}{ AMODEL AS-1133 HS } \\
\hline \multicolumn{3}{|c|}{ Full Size Conformable } \\
\hline & Value & Source or Description \\
\hline \multicolumn{3}{|r|}{ Inputs } \\
\hline \multicolumn{3}{|l|}{ Material Propertles } \\
\hline Density $(\mathrm{lb} / \mathrm{in} 3)$ & 0.0528 & Amoco \\
\hline Mtt $\operatorname{Cost}(\$ / \mathrm{B})$ & 2.85 & Amoco \\
\hline TD Tens Strength (psi) & 7296 & Tank Burst, $99 \%$ probability \\
\hline FD Flex Strength (psi) & 46000 & Amoco \\
\hline FD Flex Modulus (psi) & 1650000 & Amoco \\
\hline FD Fail Strain (in/in) & 0.0250 & Amoco \\
\hline Poisson's Ratio & 0.41 & Amoco \\
\hline \multicolumn{3}{|l|}{ Fabrication } \\
\hline Fab Cost (\$tank) & 200.00 & Estimate \\
\hline \multicolumn{3}{|l|}{ Requirements } \\
\hline Burst Pressure (psi) & 1000 & $4 x$ operating pressure \\
\hline Impact (in-lbs) & 265 & pendulum impact \\
\hline \multicolumn{3}{|l|}{ Design Geometry } \\
\hline Conformable? & 1) & $1=$ conformable, $0=$ cylinders \\
\hline Wh (in) & 24.00 & Tank Width \\
\hline$W v$ (in) & 14.00 & Tank Thickness \\
\hline$L$ (in) & 36.00 & Tank Length \\
\hline Nh (integer) & 3 & Number of cells across width \\
\hline Nv (integer) & 1 & Number of cells through thickness \\
\hline$b / r$ (ratio) & 0.5000 & Dome height/radius ratio \\
\hline Ch/r (ratio) & 0.7143 & Cell width/radius, optimize for max inside vol. \\
\hline \multicolumn{3}{|c|}{ Calculations } \\
\hline Cu/r (ratio) & - & Cell thickness/radius \\
\hline$r$ (in) & 7.0000 & Cell wall radius \\
\hline $\mathrm{Ch}$ (in) & 5.0000 & Coll width \\
\hline Ov (in) & - & Cell thickness \\
\hline ti (in) & 0.2422 & thickness of outer wall for brittle impact \\
\hline ts (in) & 0.9594 & thickness of outer wall for strength \\
\hline $\operatorname{tr}(\mathrm{in})$ & 0.9594 & thickness of outer wall \\
\hline the (in) & - & thickness of horizontal webs \\
\hline to (in) & 0.6853 & thickness of vertical webs \\
\hline $\mathrm{tD}$ (in) & 1.9189 & thickness of domes \\
\hline theta $h$ (rad) & -1 & \\
\hline theta $v$ (rad) & 1.2056 & \\
\hline At (in2) & 290.90 & Total cross section area of tank profile \\
\hline $\operatorname{Ap}($ in2) & 79.74 & Cross section area of walls \\
\hline Sd (in2) & 775.74 & Approximate surface area of domes \\
\hline Vd (in3) & 1357.54 & Approximate volume of domes \\
\hline$V t$ (in3) & 9793.70 & Total extemal volume of tank \\
\hline \multicolumn{3}{|c|}{ Outputs } \\
\hline$V_{p}$ (in3) & 3801.08 & Total volume of tank walls and domes \\
\hline Vi (in3) & 5992.63 & Internal volume \\
\hline gallons (gal) & 25.94 & Intemal volume \\
\hline Veff $(\%)$ & $49.54 \%$ & Volume efficiency \\
\hline weight (lbs) & 200.70 & Empty tank weight \\
\hline material cost (\$) & 571.99 & \\
\hline total cost $(\$)$ & 771.99 & \\
\hline V/sW (in3/s-lb) & 0.03868 & Combined Performance \\
\hline
\end{tabular}


Table 14, Cost Model for FORTRON 0214 C1 Tank

\begin{tabular}{|c|c|c|}
\hline \multicolumn{3}{|c|}{ FORTRON 0214 C1 PPS } \\
\hline \multicolumn{3}{|c|}{ Full Size Conformable } \\
\hline & Value & Source or Description \\
\hline \multicolumn{3}{|r|}{ Inputs } \\
\hline \multicolumn{3}{|l|}{ Material Properties } \\
\hline Density (lb/in3) & 0.0488 & Hoechst Celanese \\
\hline $\mathrm{N}$ t $\mathrm{Cost}(\mathbf{S} / \mathrm{ib})$ & 5.65 & Hoechst Celanese \\
\hline TD Tens Strength (psi) & 12500 & FD Tensile Strngth, Hoechst \\
\hline FD Flex Strength (psi) & 21000 & Hoechst Celanese \\
\hline FD Flex Modulus (psi) & 600000 & Hoechst Celanese \\
\hline FD Fail Strain (in/in) & 0.0400 & Range $.03-.06$, Hoechst \\
\hline Poisson's Ratio & 0.41 & Estimate \\
\hline \multicolumn{3}{|l|}{ Fabrication } \\
\hline \begin{tabular}{|l|l|} 
& Fab Cost (\$/tank) \\
\end{tabular} & 200.00 & Estimate \\
\hline \multicolumn{3}{|l|}{ Requirements } \\
\hline Burst Pressure (psi) & 1000 & $4 x$ operating pressure \\
\hline Impact (in-lbs) & 265 & pendulum impact \\
\hline \multicolumn{3}{|l|}{ Design Geometry } \\
\hline \begin{tabular}{|l|l} 
& Conformable? \\
\end{tabular} & 1 & $1=$ conformable, $0=$ cylinders \\
\hline Wh (in) & 24.00 & Tank Width \\
\hline$W_{v}$ (in) & 14.00 & Tank Thickness \\
\hline$L$ (in) & 36.00 & Tank Length \\
\hline Nh (integer) & 3 & Number of cells across width \\
\hline \begin{tabular}{|l} 
Nv (integer) \\
\end{tabular} & 1 & Number of cells through thickness \\
\hline$b / r$ (ratio) & 0.5000 & Dome height/radius ratio \\
\hline Ch/r (ratio) & 0.7143 & Cell width/radius, optimize for max inside vol. \\
\hline \multicolumn{3}{|c|}{ Calculations } \\
\hline Cv/r (ratio) & - & Cell thickness/radius \\
\hline$r$ (in) & 7.0000 & Cell wall radius \\
\hline $\operatorname{Ch}$ (in) & 5.0000 & Cell width \\
\hline $\mathrm{Cv}(\mathrm{in})$ & - & Cell thickness \\
\hline$t$ (in) & 0.4443 & thickness of outer wall for ductile impact \\
\hline ts (in) & 0.5600 & thickness of outer wall for strength \\
\hline$t$ (in) & 0.5600 & thickness of outer wall \\
\hline th (in) & - & thickness of horizontal webs \\
\hline tv (in) & 0.4000 & thickness of vertical webs \\
\hline tD (in) & 1.1200 & thickness of domes \\
\hline theta h (rad) & - & \\
\hline theta $v$ (rad) & 12056 & \\
\hline At (in2) & 290.90 & Total cross section area of tank profile \\
\hline Ap (in2) & 46.54 & Cross section area of walls \\
\hline Sd (in2) & 775.74 & Approximate surface area of domes \\
\hline Volin3) & 1357.54 & Approximate volume of domes \\
\hline$V_{t}$ (in3) & 9793.70 & Total external volume of tank \\
\hline \multicolumn{3}{|c|}{ Outputs } \\
\hline$V_{p}$ (in3) & 2218.61 & Total volume of tank walls and domes \\
\hline$V$ i (in3) & 7575.09 & Internal volume \\
\hline gallons (gal) & 32.79 & Internal volume \\
\hline Veff $(\%)$ & $62.62 \%$ & Volume efficiency \\
\hline weight (lbs) & 108.23 & Empty tank weight \\
\hline material cost (\$) & 611.52 & \\
\hline total cost (\$) & 811.52 & \\
\hline V/SW (in3/S-lb) & 0.08524 & Combined Performance \\
\hline
\end{tabular}


Table 15, Cost Model for Target Material

\begin{tabular}{|c|c|c|}
\hline \multicolumn{3}{|c|}{ Target Material } \\
\hline \multicolumn{3}{|c|}{ Full Size Conformable } \\
\hline & Value & Source or Description \\
\hline \multicolumn{3}{|r|}{ Inputs } \\
\hline \multicolumn{3}{|l|}{ Materlal Properties } \\
\hline Density $(\mathrm{lb} / \mathrm{in} 3)$ & 0.0500 & \\
\hline Mtt Cost (\$/b) & 6.00 & \\
\hline TD Tens Strength (psi) & 18000 & \\
\hline FD Flex Strength (psi) & 18000 & \\
\hline FD Flex Modulus (psi) & 500000 & \\
\hline FD Fail Strain (in/in) & 0.0600 & \\
\hline Poisson's Ratio & 0.41 & \\
\hline \multicolumn{3}{|l|}{ Fabrication } \\
\hline Fab Cost (S/tank) & 200.00 & Estimate \\
\hline \multicolumn{3}{|l|}{ Requirements } \\
\hline Burst Pressure (psi) & 1000 & $4 \times$ operating pressure \\
\hline Impact (in-lbs) & 265 & pendulum impact \\
\hline \multicolumn{3}{|l|}{ Design Geometry } \\
\hline Conformable? & 1) & $1=$ conformable, $0=$ cylinders \\
\hline Wh (in) & 24.00 & Tank Width \\
\hline Wv (in) & 14.00 & Tank Thickness \\
\hline$L$ (in) & 36.00 & Tank Length \\
\hline Nh (integer) & 3 & Number of cells across width \\
\hline Nv (integer) & 1 & Number of cells through thickness \\
\hline b/r (ratio) & 0.5000 & Dome height/radius ratio \\
\hline $\mathrm{Ch} / \mathrm{r}$ (ratio) & 0.7143 & Cell width/radius, optimize for max inside vol. \\
\hline \multicolumn{3}{|c|}{ Calculations } \\
\hline Cv/r (ratio) & - & Cell thickness/radius \\
\hline$r$ (in) & 7.0000 & Cell wall radius \\
\hline $\operatorname{Ch}$ (in) & 5.0000 & Cell width \\
\hline Cv (in) & -1 & Cell thickness \\
\hline ti(in) & 0.3328 & thickness of outer wall for ductile impact \\
\hline ts (in) & 0.3889 & thickness of outer wall for strength \\
\hline tr (in) & 0.3889 & thickness of outer wall \\
\hline th (in) & -1 & thickness of horizontal webs \\
\hline to (in) & 0.2778 & thickness of vertical webs \\
\hline tD (in) & 0.7778 & thickness of domes \\
\hline theta $\mathrm{h}$ (rad) & -1 & \\
\hline theta $v(\mathrm{rad})$ & 1.2056 & \\
\hline At (in2) & 290.90 & Total cross section area of tank profile \\
\hline Ap (in2) & 32.32 & Cross section area of walls \\
\hline Sd (in2) & 775.74 & Approximate surface area of domes \\
\hline Vd (in3) & 1357.54 & Approximate volume of domes \\
\hline Vt (in3) & 9793.70 & Total external volume of tank \\
\hline \multicolumn{3}{|c|}{ Outputs } \\
\hline$V_{p}(\mathrm{in} 3)$ & 1540.70 & Total volume of tank walls and domes \\
\hline$V_{i}$ (in 3$)$ & 8253.00 & Internal volume \\
\hline gallons (gal) & 35.73 & Internal volume \\
\hline Veff $(\%)$ & $68.23 \%$ & Volume efficiency \\
\hline weight (lbs) & 77.04 & Empty tank weight \\
\hline material cost (\$) & 462.21 & \\
\hline total cost (\$) & 662.21 & \\
\hline V/SW (in3/s-lb) & 0.16178 & Combined Performance \\
\hline
\end{tabular}


Table 16, Molding Results, Subscale Design 2

\begin{tabular}{|c|c|c|c|c|c|c|c|c|c|}
\hline $\begin{array}{c}\text { Serial } \\
\text { Number }\end{array}$ & Material & Washed & Cracked & Cutt & Inserts & Good & Remarks & $\begin{array}{c}\text { Burst } \\
\text { Pressure } \\
\text { (psi) } \\
\end{array}$ & Failure Mode \\
\hline 1 & A & 1 & & $Y$ & A & & & & \\
\hline 2 & A & 1 & & & $\bar{A}$ & $\mathbf{Y}$ & $\begin{array}{l}\text { possible hairline cracks by } \\
\text { weld }\end{array}$ & 188 & $\begin{array}{l}\text { leaked on weld; } \\
\text { longitudinal split on side }\end{array}$ \\
\hline 3) & A & & $Y$ & & A & & & & \\
\hline 4 & A & & $\bar{Y}$ & & $A$ & & opened mold too early & & \\
\hline 5 & A & 1,NCF & $Y$ & $\mathbf{Y}$ & A & & & & \\
\hline 6 & A & & $Y$ & & A & & & & \\
\hline 7 & A & & $Y$ & & A & & & & \\
\hline 8 & A & H,NCF & & & A & & & & \\
\hline 9) & A & $\mathrm{H}, \mathrm{NCF}$ & $Y$ & & A & & fine cracks during wash & & \\
\hline 10 & A & & $Y$ & & A & & & & \\
\hline 11 & A & & $\mathbf{Y}$ & & $\mathbf{s}$ & & & & \\
\hline 12 & $A$ & & $Y$ & & SA & & & & \\
\hline 13) & A & $\mathrm{H}$ & & & SA & $Y$ & & 430 & broke in half at weld line \\
\hline 14 & A & $\mathrm{H}$ & & & SA & $\mathbf{Y}$ & & 289 & $\begin{array}{l}\text { cracked and leaked at } \\
\text { weld }\end{array}$ \\
\hline 15 & $F$ & $H$ & $\mathbf{Y}$ & & SA & & $\begin{array}{l}\text { cracked through dome } \\
\text { overnight }\end{array}$ & & \\
\hline 16 & $F$ & $\mathrm{H}$ & $\mathbf{Y}$ & & SA & & cracked during annealing & & \\
\hline 17 & $F$ & $\mathrm{H}$ & $\mathbf{Y}$ & & SA & & & & \\
\hline 18 & $F$ & $\mathrm{H}$ & $Y$ & & SA & & cracked during annealing & & \\
\hline 19 & $F$ & $\mathrm{H}, \mathrm{I}$ & $Y$ & & SA & & & & \\
\hline 20 & $\mathbf{F}$ & $H$ & & & SA & $\mathbf{Y}$ & & 643 & $\begin{array}{l}\text { fractured into numerous } \\
\text { pieces }\end{array}$ \\
\hline 21 & $F$ & H & & & SA & $\mathbf{Y}$ & & 839 & $\begin{array}{l}\text { fractured into numerous } \\
\text { pieces }\end{array}$ \\
\hline
\end{tabular}

\begin{tabular}{|c|c|}
\hline Materials: & $\begin{array}{l}A=\text { AMODEL AS-1133 HS } \\
F=\text { FORTRON } \\
0214 \mathrm{C1}\end{array}$ \\
\hline Washed: & $\begin{array}{l}\text { Eimmersed } \\
H=\text { hose, internal wash } \\
\text { NCF=no cross fiow }\end{array}$ \\
\hline Inserts: & $\begin{array}{l}\mathrm{A}=\text { aluminum } \\
\mathrm{S}=\text { steel } \\
\mathrm{SA}=\text { sand filled aluminum }\end{array}$ \\
\hline
\end{tabular}

Table 17, Welded Bottle Burst Summary

\begin{tabular}{|l||c|c|c||}
\hline \multicolumn{1}{|c||}{} & \multicolumn{3}{c|}{$70^{\circ} \mathrm{F}$} \\
\hline Material & $\begin{array}{c}\text { Mean } \\
\text { (psi) }\end{array}$ & $\begin{array}{c}\text { Std } \\
\text { Dev } \\
(\mathrm{psi})\end{array}$ & $\mathrm{N}$ \\
\hline RTP 4001 weld & 3083.9 & 1154.5 & 10 \\
\hline RTP 4005 weld & 13829 & 755.61 & 2 \\
\hline AMODEL A-1115 weld & 7088.7 & 475.61 & 2 \\
\hline AMODEL A-1133 weld & 7339 & 614.69 & 2 \\
\hline
\end{tabular}


Table 18, Tank Burst Tests, First Subscale Design

\begin{tabular}{|c|c|c|l|}
\hline $\begin{array}{c}\text { Tank } \\
\text { Number }\end{array}$ & Test Date & $\begin{array}{c}\text { Burst } \\
\text { Pressure }\end{array}$ & \multicolumn{1}{|c|}{ Notes } \\
\hline \hline 4 & 27 March 1996 & $435 \mathrm{psi}$ & leakage around bosses \\
\hline 8 & 3 June 1996 & $\approx 350 \mathrm{psi}$ & data acquisition problem \\
\hline 10 & 3 June 1996 & $464 \mathrm{psi}$ & higher injection rate \& pressure \\
\hline 6 & 7 June 1996 & $459 \mathrm{psi}$ & cycled 15,000 times, 50-150 psi \\
\hline
\end{tabular}

Table 19, Impact Test Results

\begin{tabular}{||c|c|c|c|l||}
\hline \multirow{2}{*}{$\begin{array}{c}\text { Impact } \\
\text { Number }\end{array}$} & Tank & \multicolumn{2}{|c|}{ Energy (ft-lb) } & \multirow{2}{*}{ Observed Damage } \\
\cline { 3 - 4 } & Number & Impact & Absorbed & \\
\hline \hline 1 & 3 & 10.2 & 5.1 & pierced \\
\hline 2 & 3 & 5.0 & & none \\
\hline 3 & 3 & 7.5 & 6.1 & none \\
\hline 4 & 3 & 8.3 & 5.1 & pierced \\
\hline 5 & 7 & 7.2 & 6.0 & surface dent, interior cracks \\
\hline 6 & 7 & 7.0 & 4.9 & interior cracks \\
\hline 7 & 7 & 6.3 & 4.3 & interior cracks \\
\hline 8 & 7 & 5.3 & 4.3 & interior cracks, possible damage from \#7 \\
\hline
\end{tabular}

Table 20, Target Properties for Material Development

\begin{tabular}{|l|c|c|}
\hline Property & Current & Target \\
\hline $\begin{array}{l}\text { Strength in } \\
\text { weak direction }\end{array}$ & $12 \mathrm{ksi}$ & $>18 \mathrm{ksi}$ \\
\hline Modulus & $600 \mathrm{ksi}$ & $>500 \mathrm{ksi}$ \\
\hline Strain & $4.0 \%$ & $>6.0 \%$ \\
\hline Mold Shrinkage & $1.2 \%$ & $<0.5 \%$ \\
\hline Cost/pound & $\$ 5.65$ & $<\$ 6.00$ \\
\hline
\end{tabular}



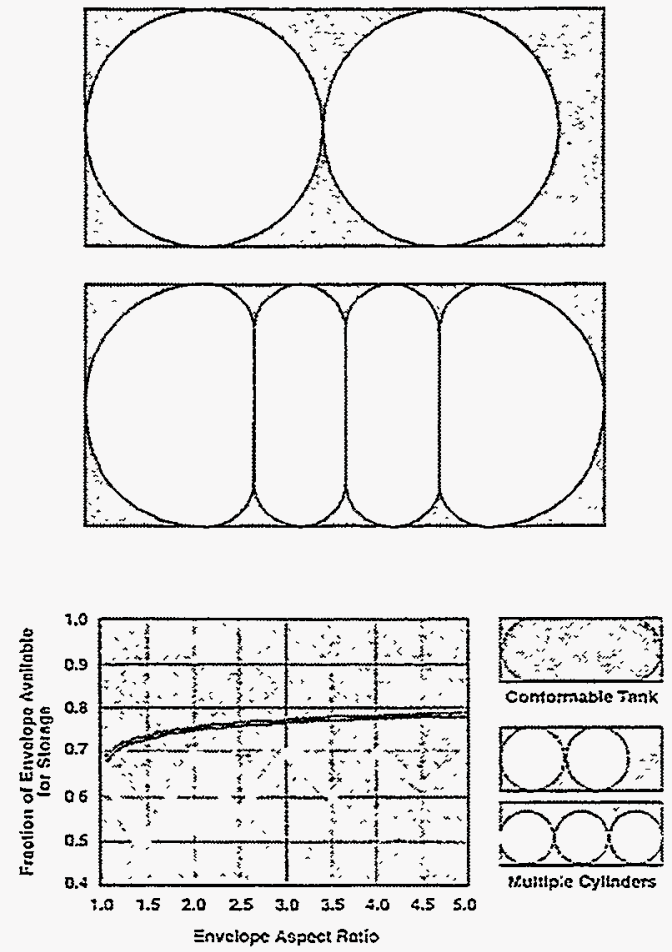

Figure 1, The Conformable Storage Concept

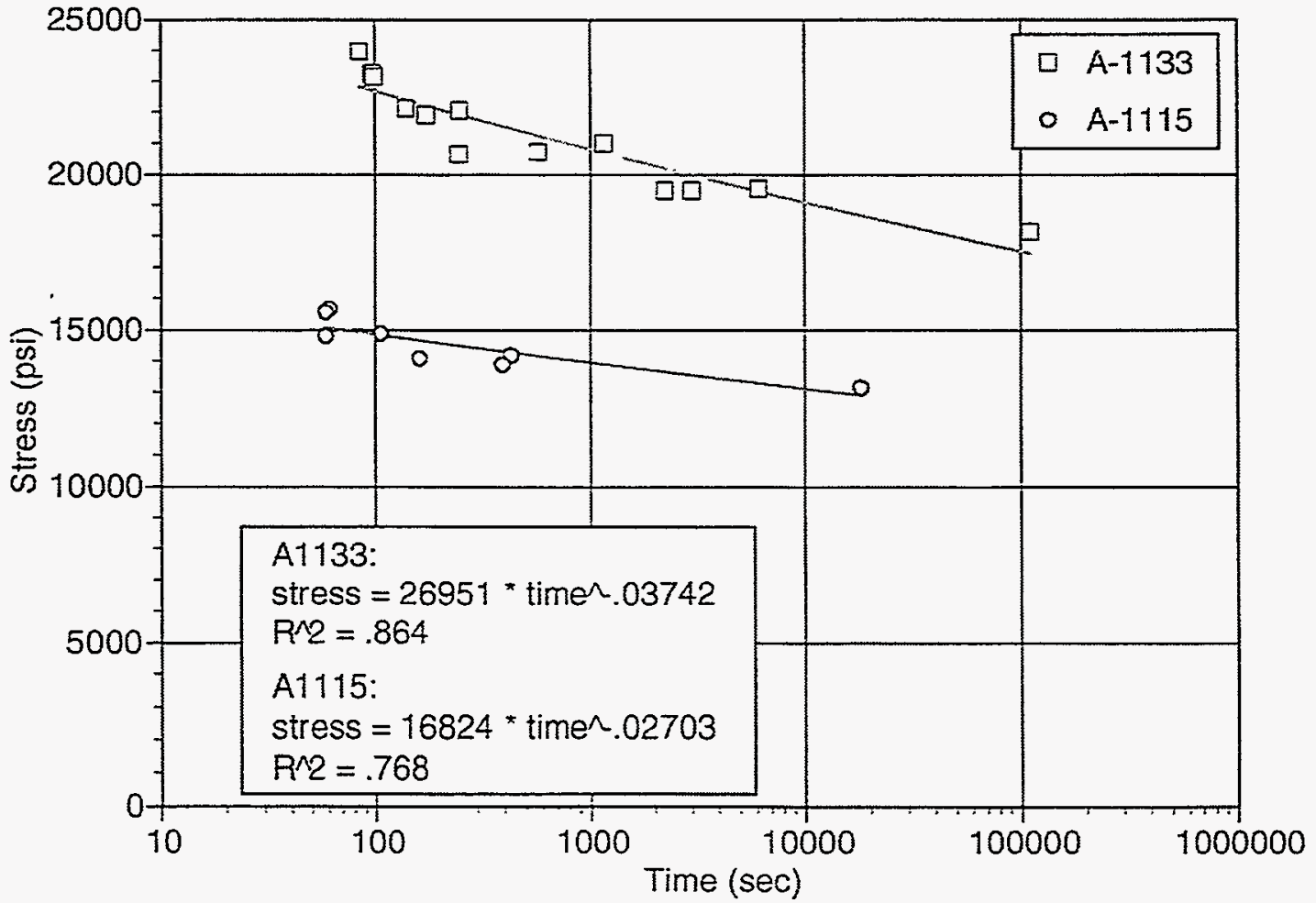

Figure 2, Creep Rupture at $180^{\circ} \mathrm{F}$ 


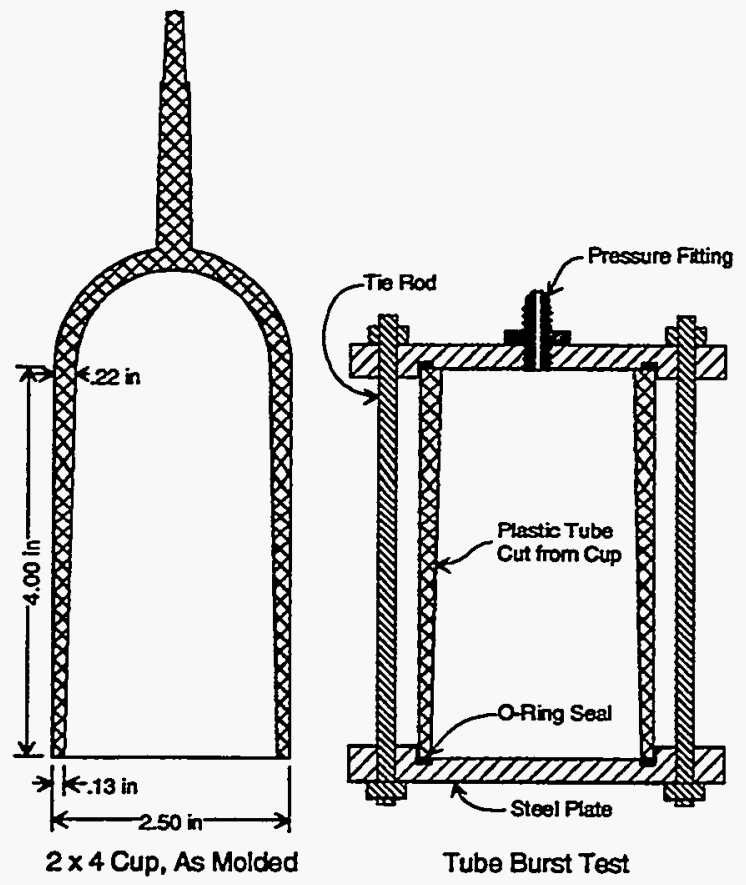

Figure 3, Cup Mold and Tube Burst Test

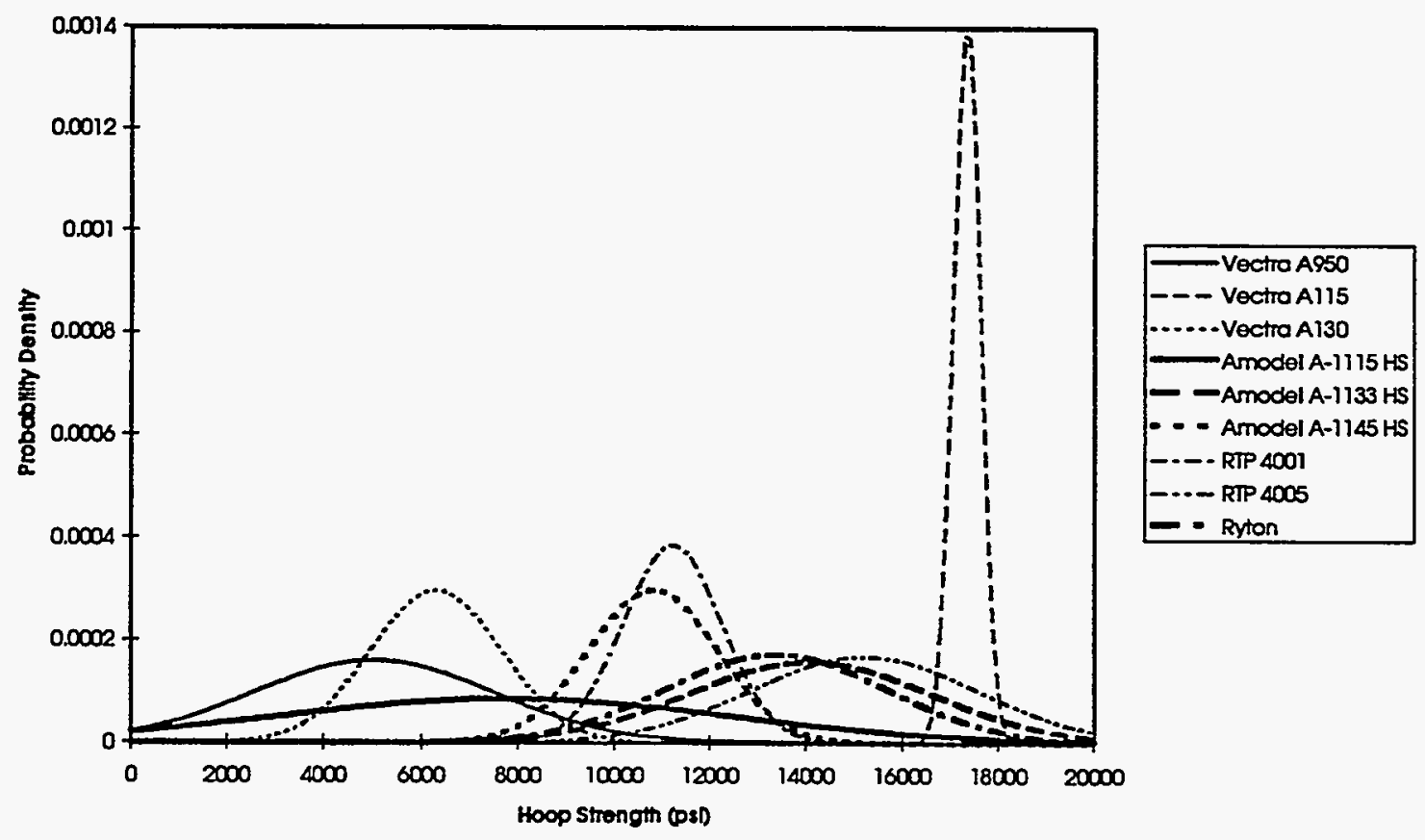

Figure 4, Tube Burst Results 


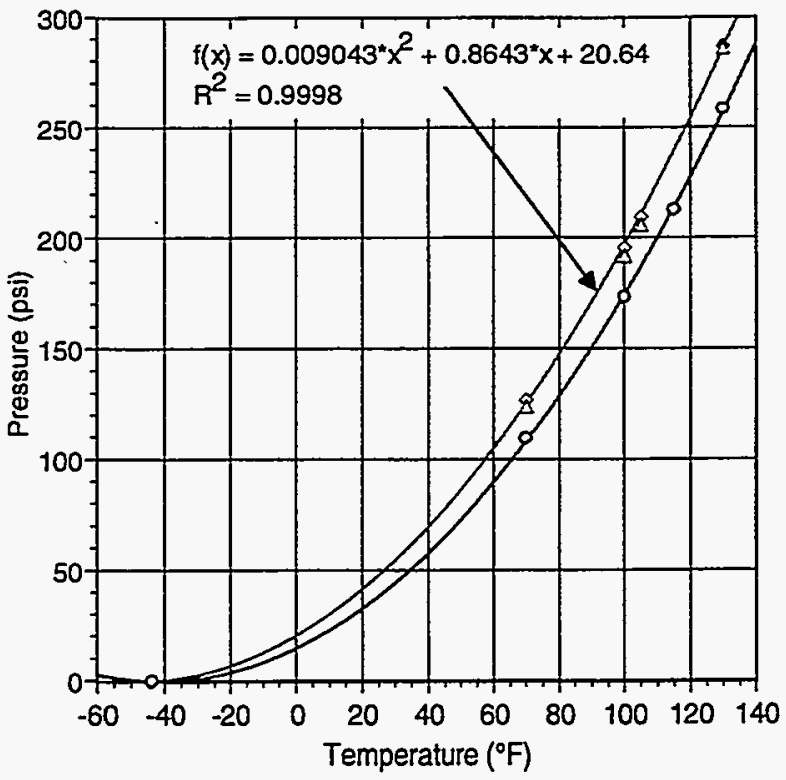

$$
\begin{aligned}
& \text { - commercial Propane } 1 \\
& \text { ^ Commercial Propane } 2 \\
& \text { - Pure Propane }
\end{aligned}
$$

Figure 5, Propane Pressure versus Temperature
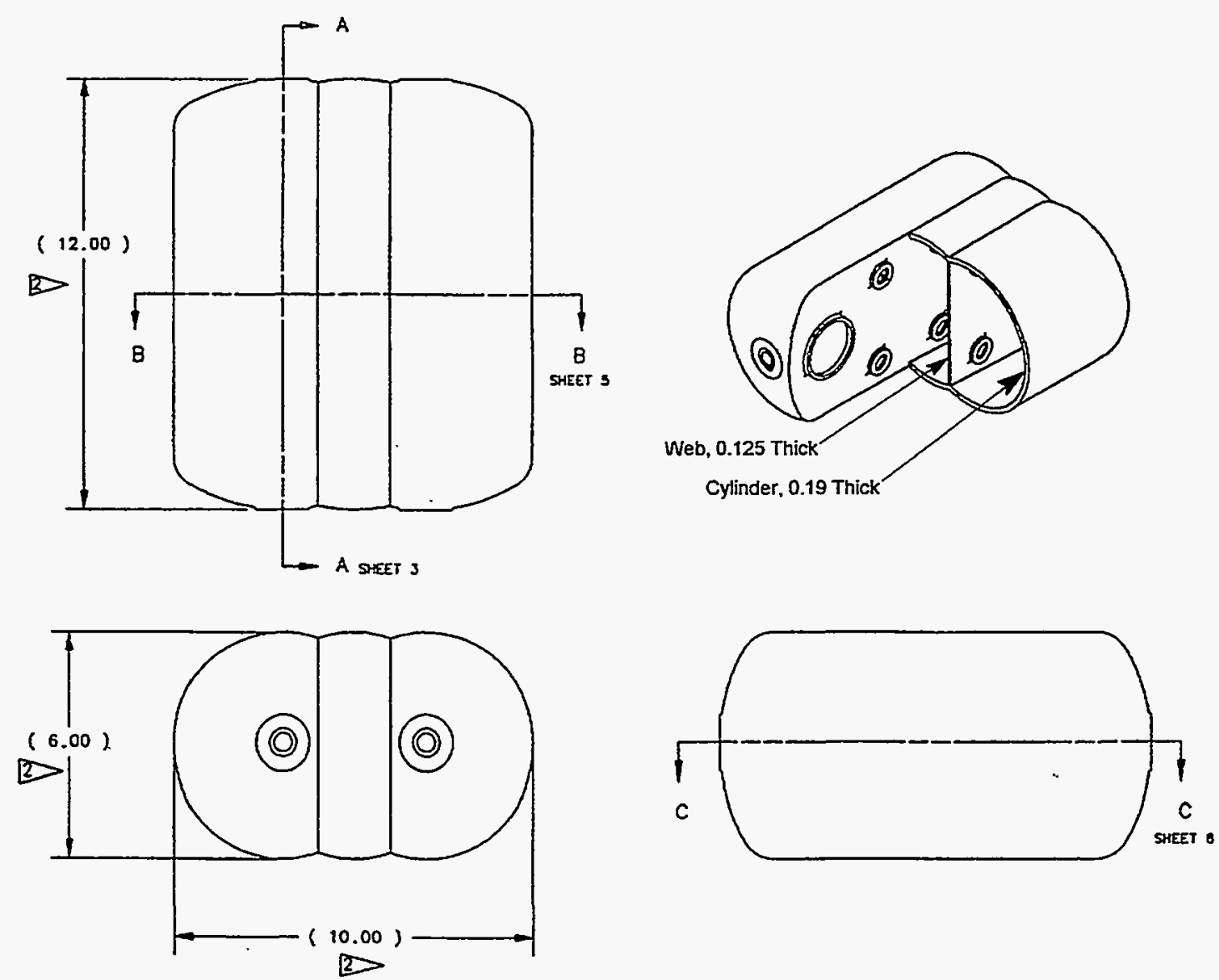

Figure 6, First Subscale Tank Design 


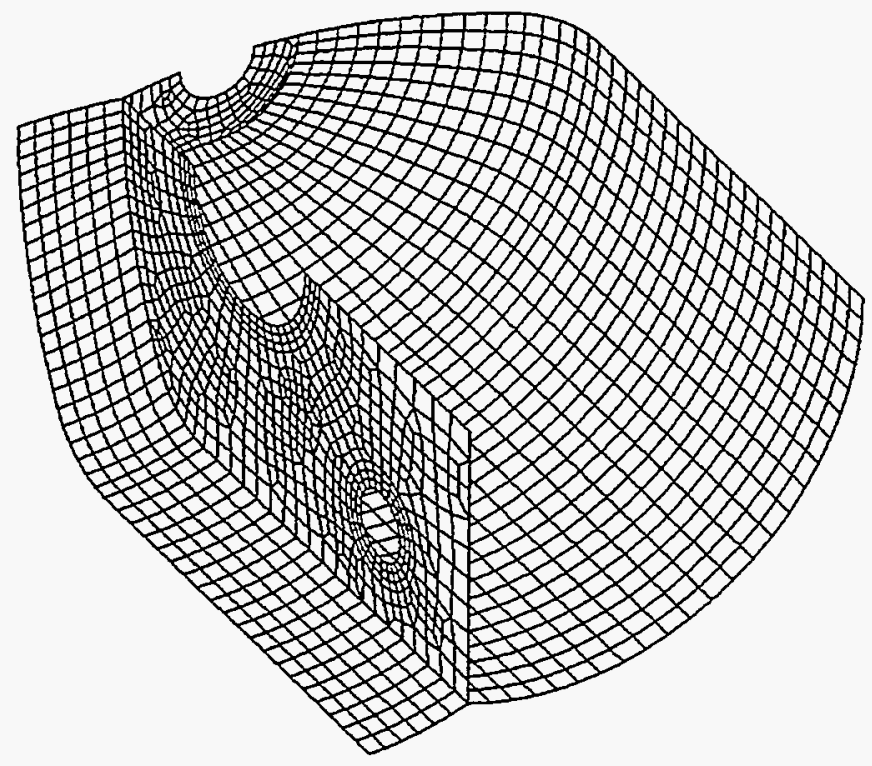

Figure 7, Shell Element Model of First Subscale Tank

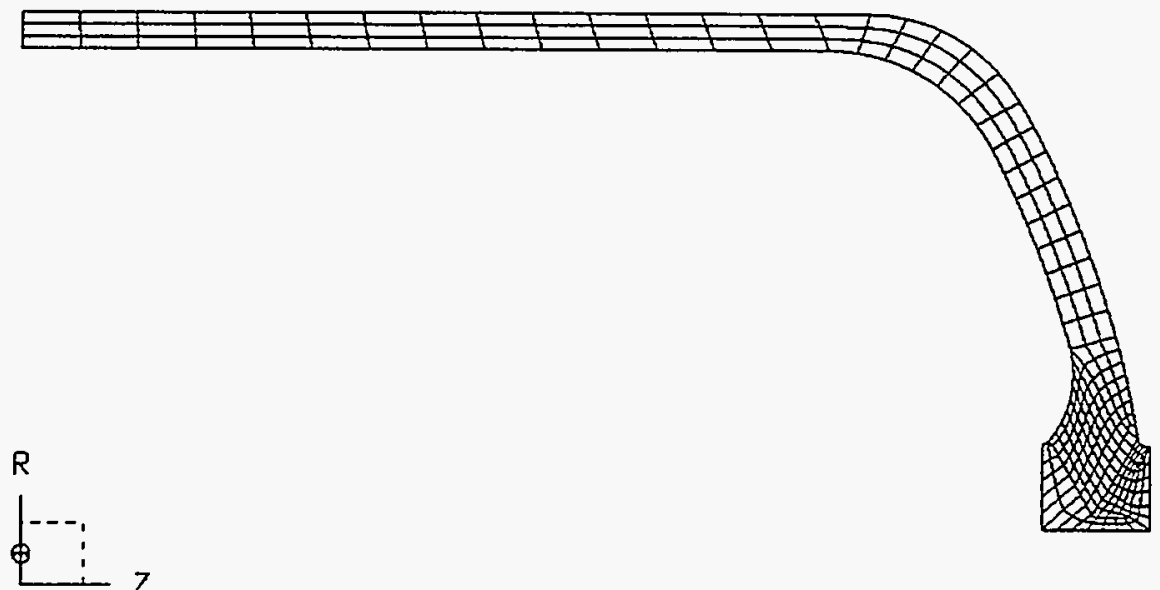

Figure 8, Axisymmetric Model of First Subscale Tank 


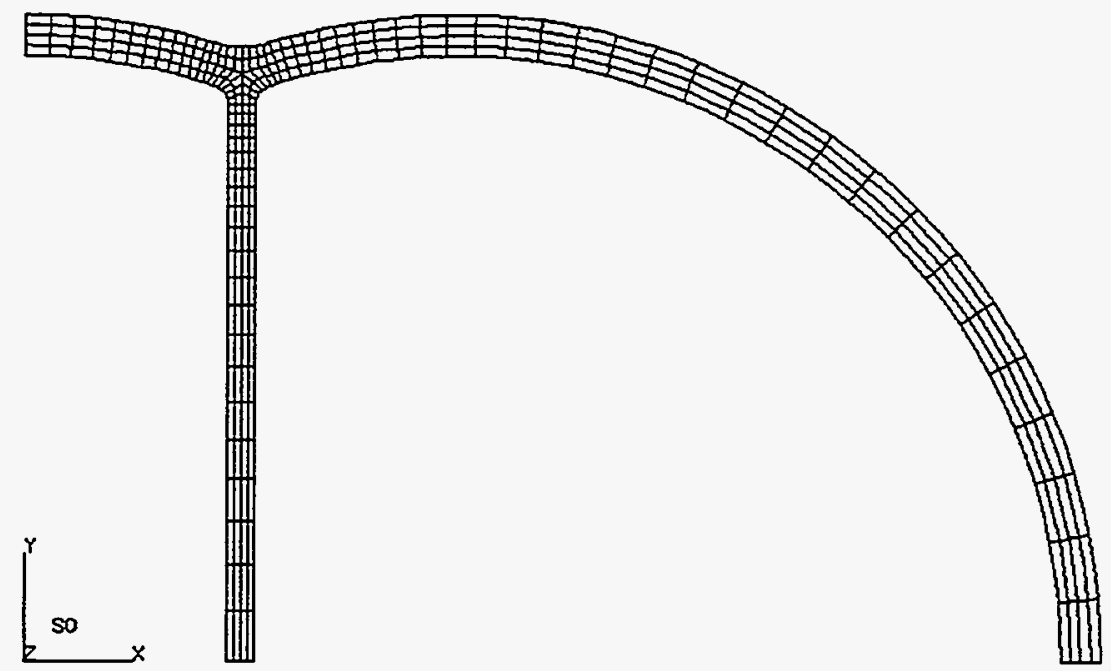

Figure 9, Cross Section Plane Strain Model of First Subscale Tank

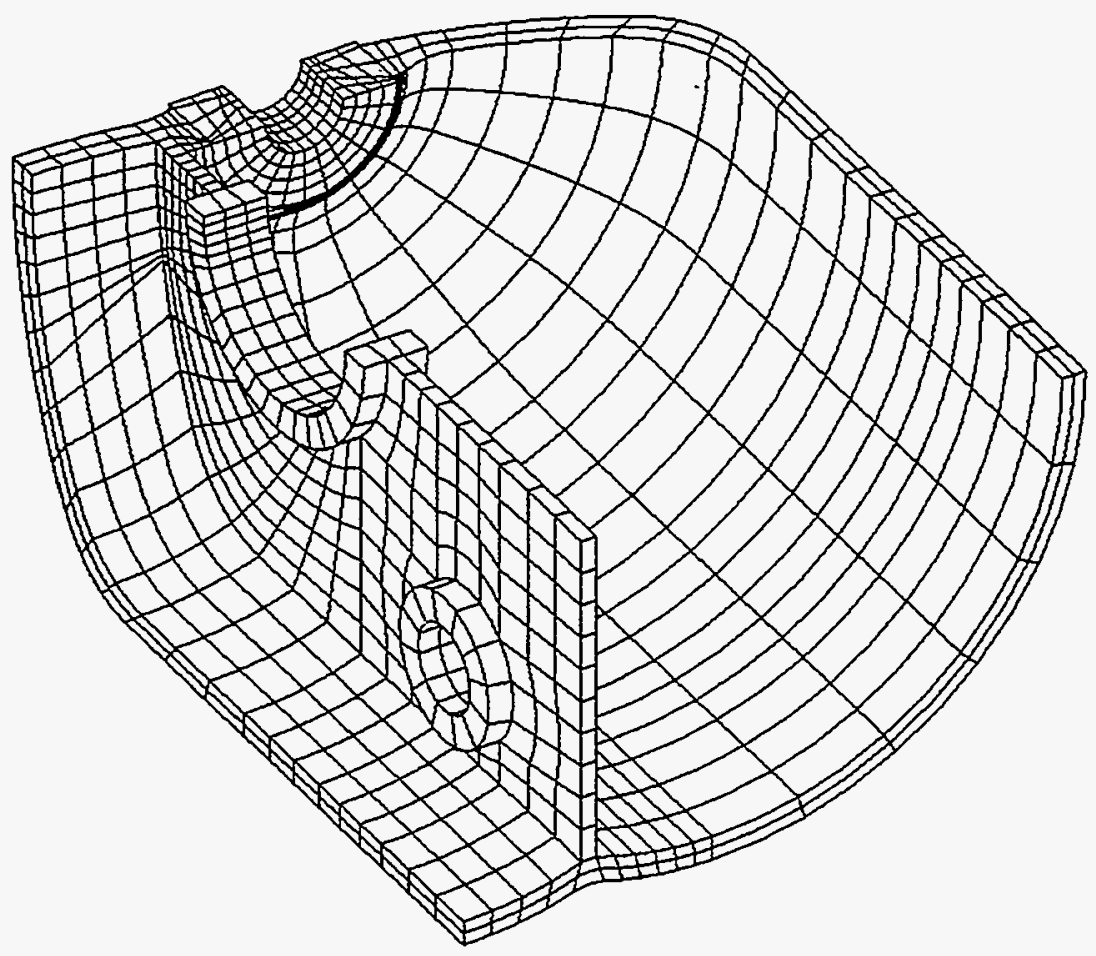

Figure 10, 3-D Solid Element Model of First Subscale Tank 

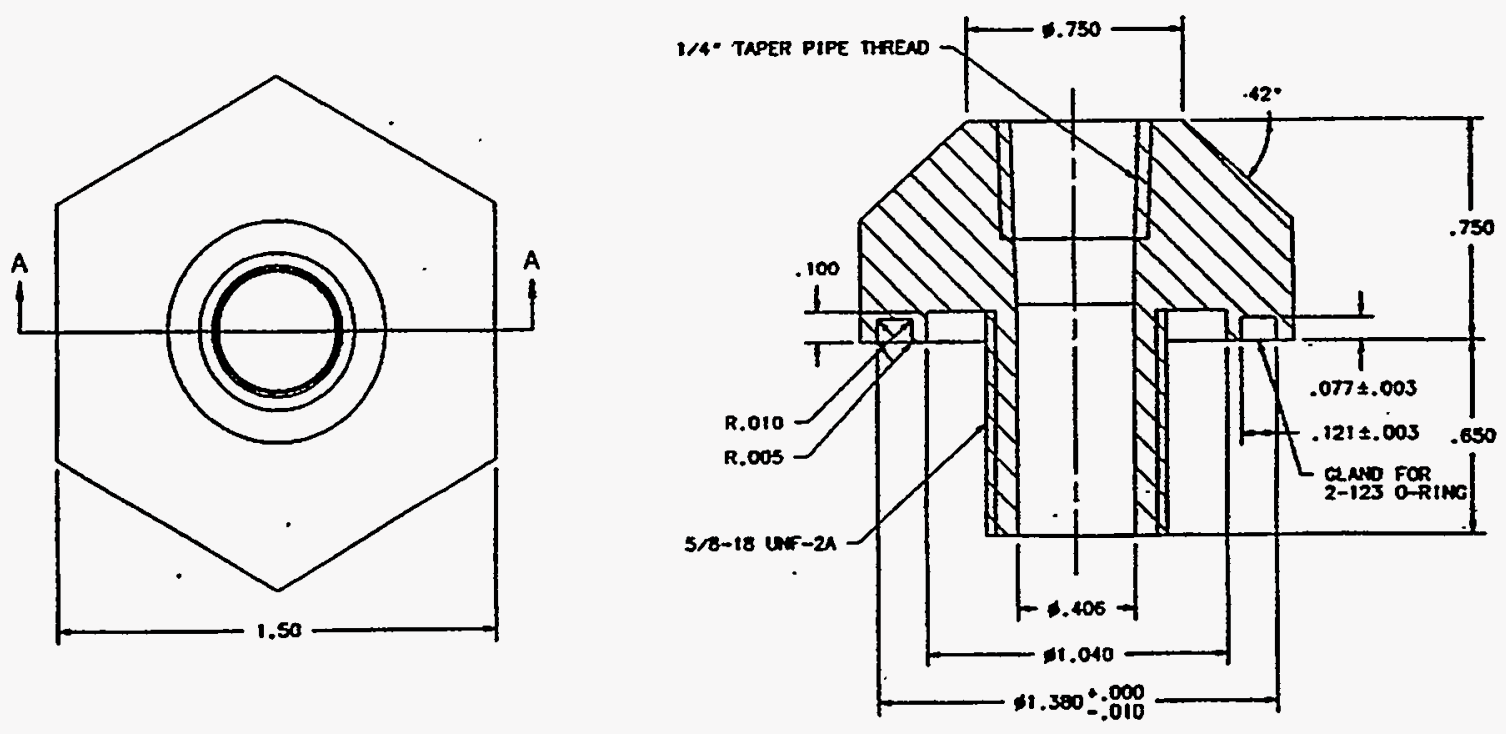

SECTION A-A

Figure 11, Port Fitting Designed to Eliminate Leakage

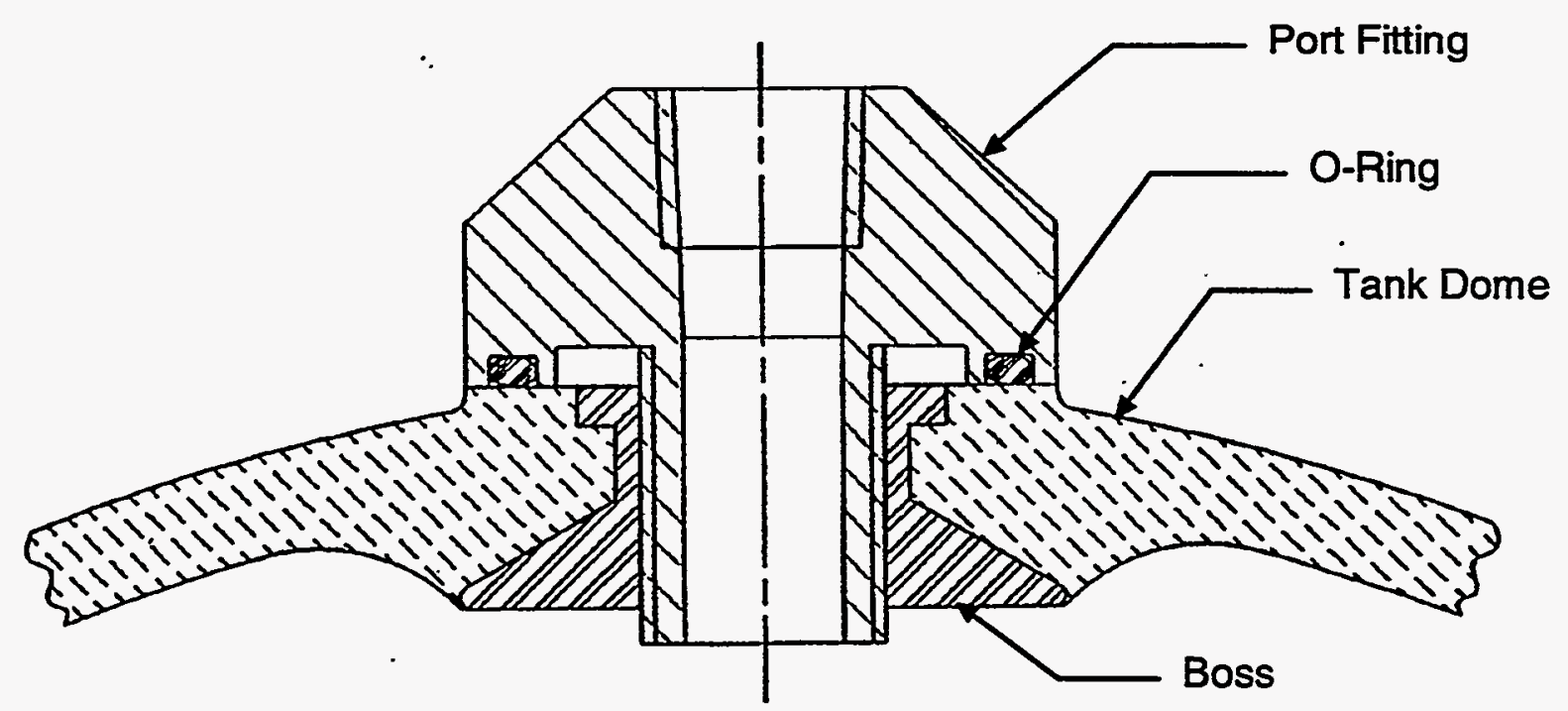

Figure 12, Port Fitting Seals Against Plastic Face 
Boss Shrinkage Analysis

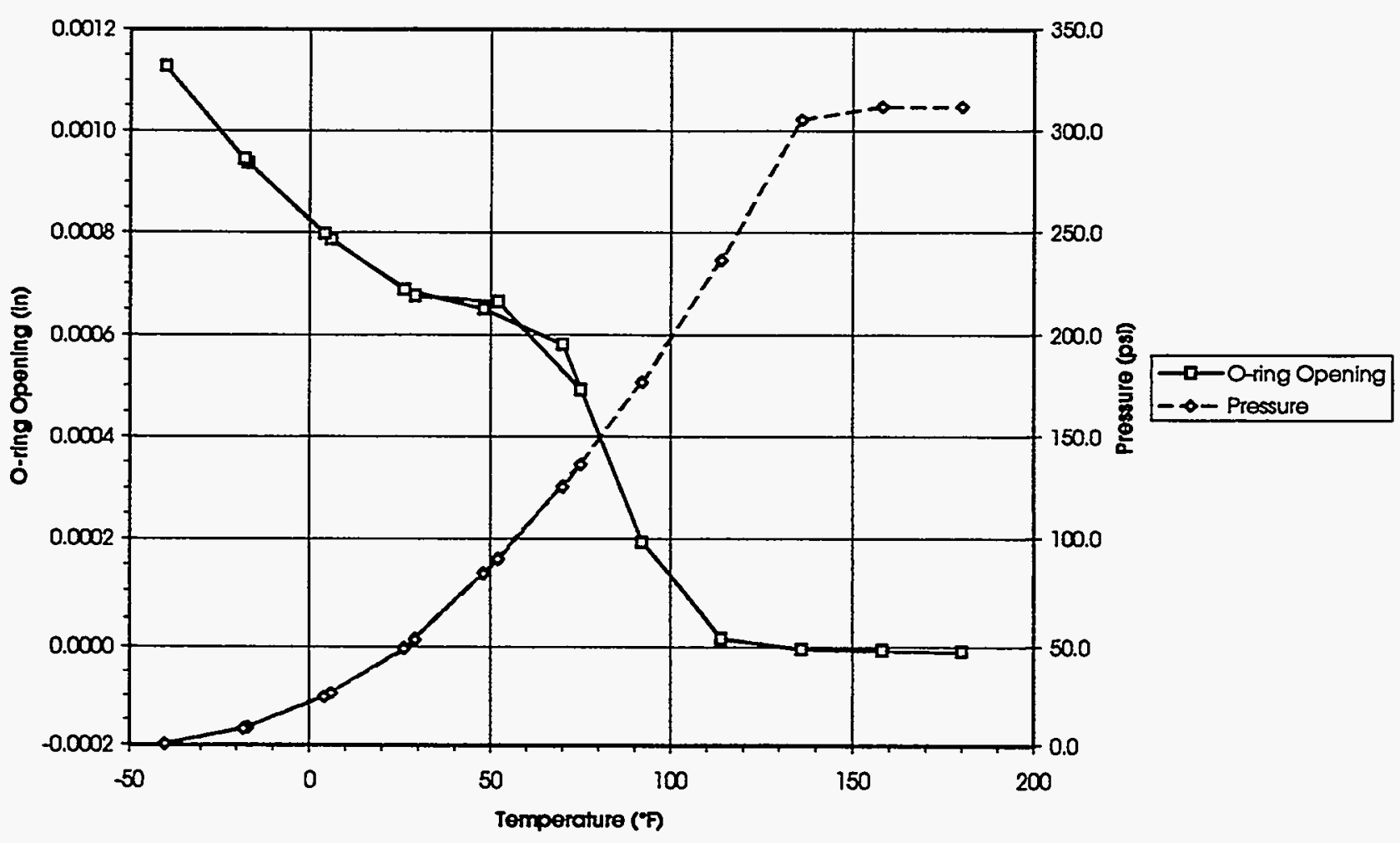

Figure 13, Boss Seal Gap Opening Analysis 

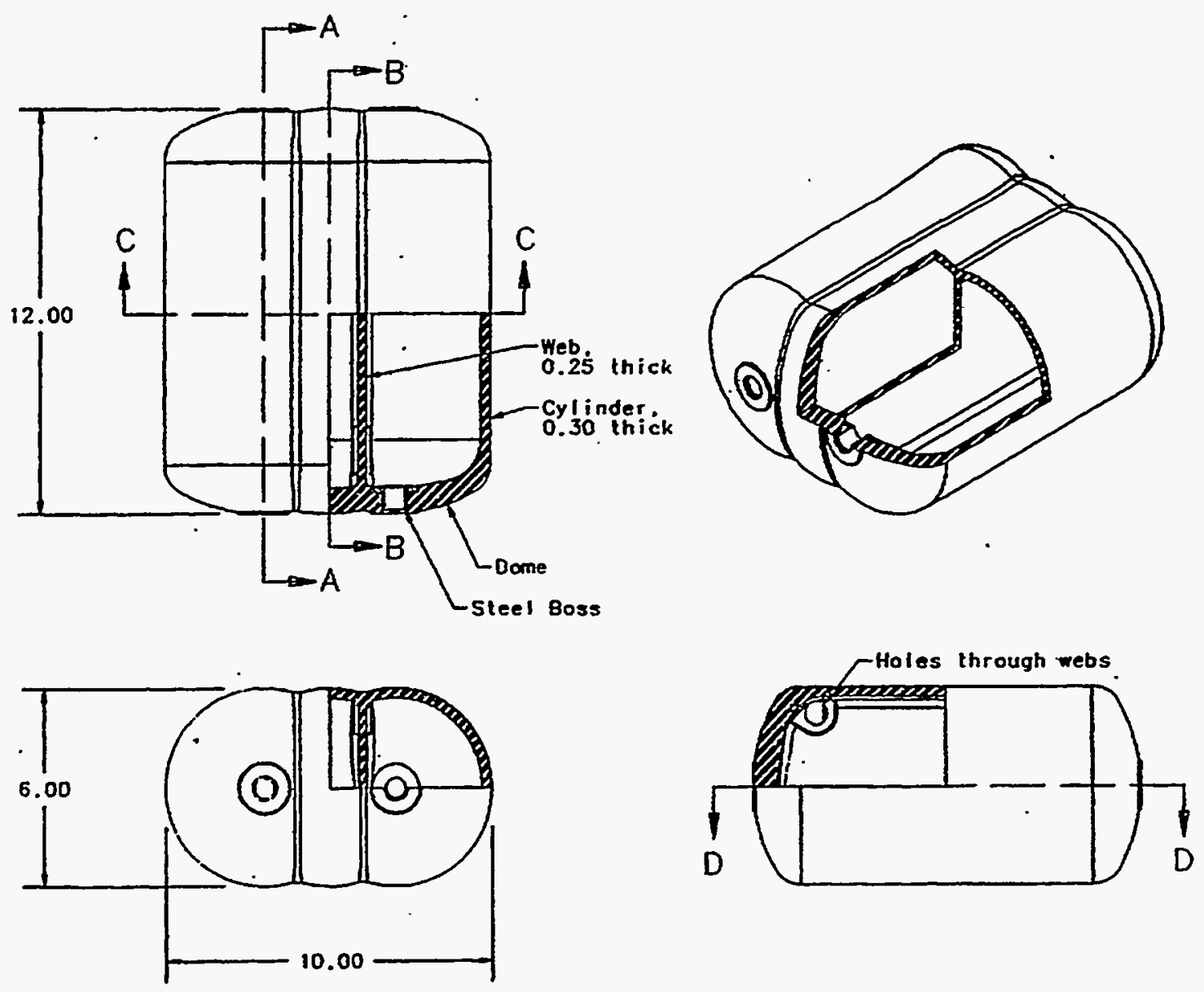

Figure 14, Intermediate Subscale Tank Design

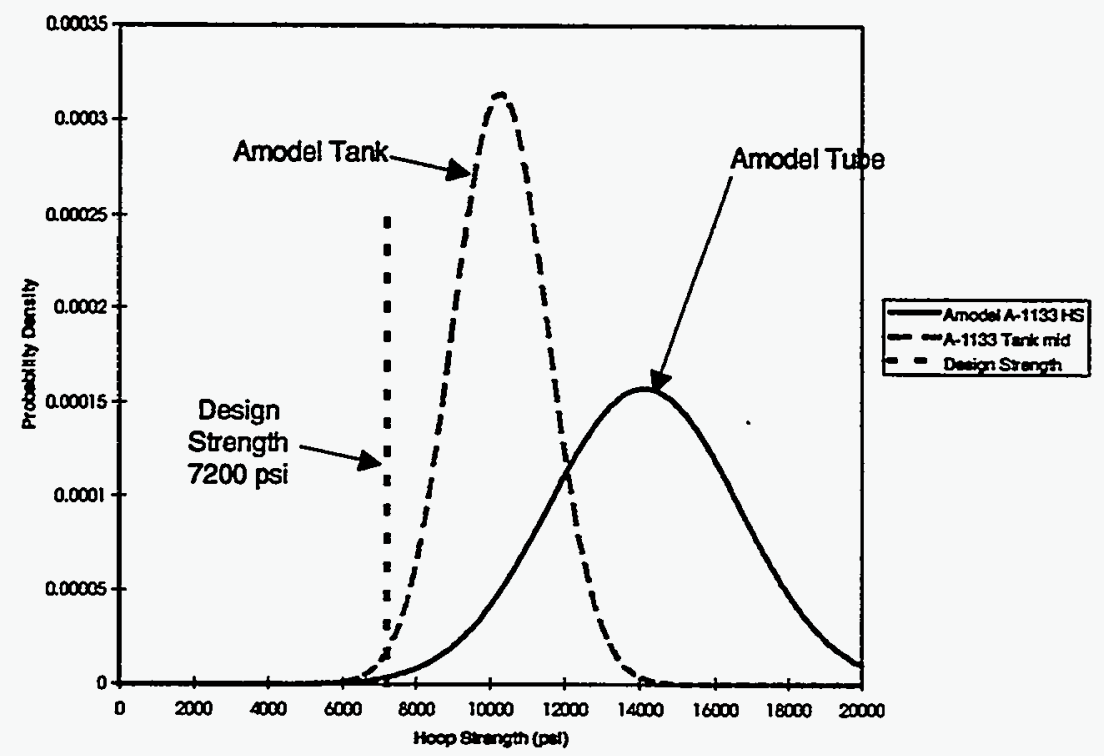

Figure 15, Design Strength for Subscale Tank Design 2 


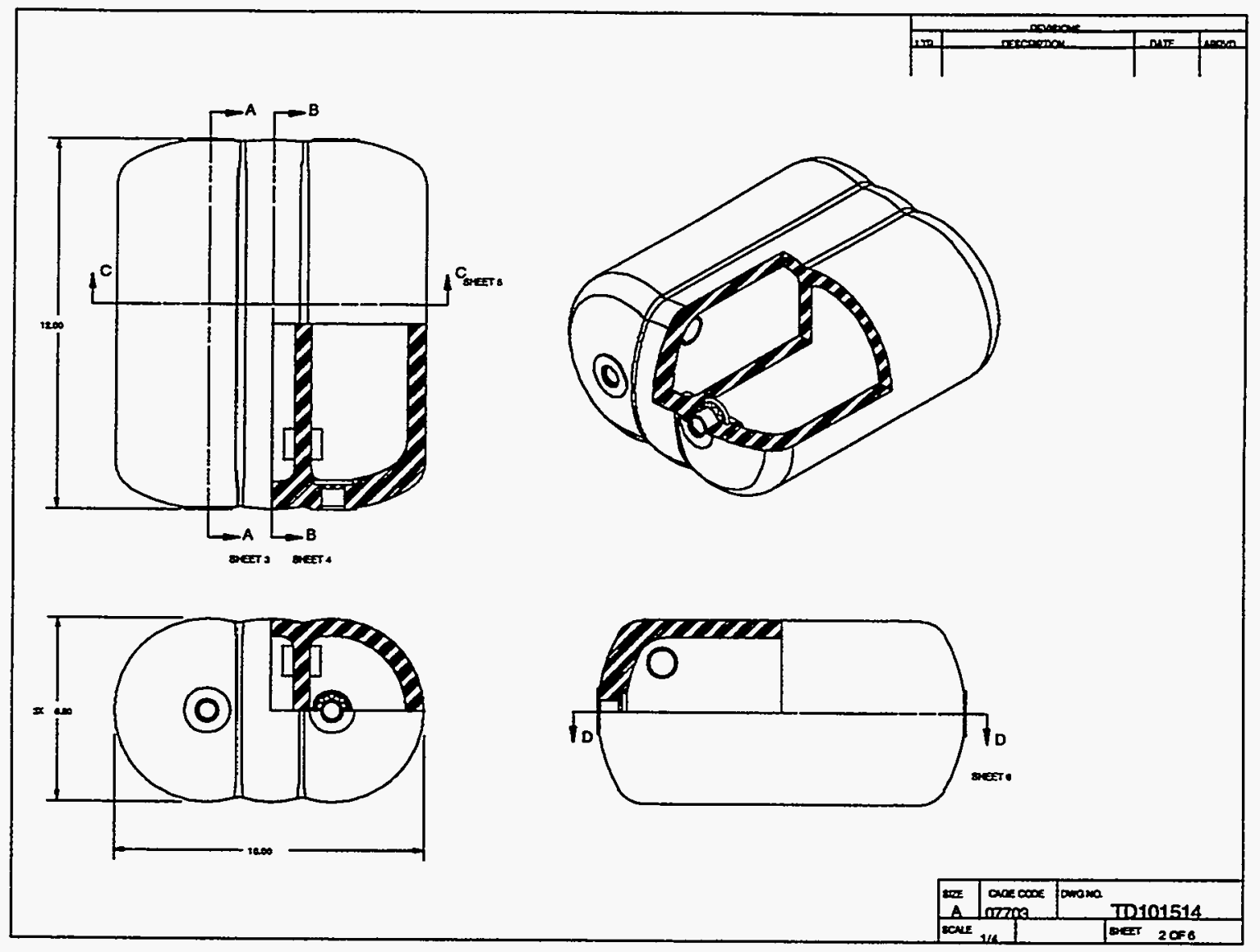

Figure 16, Subscale Tank Design 2

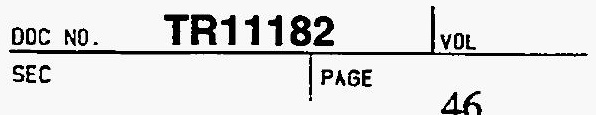



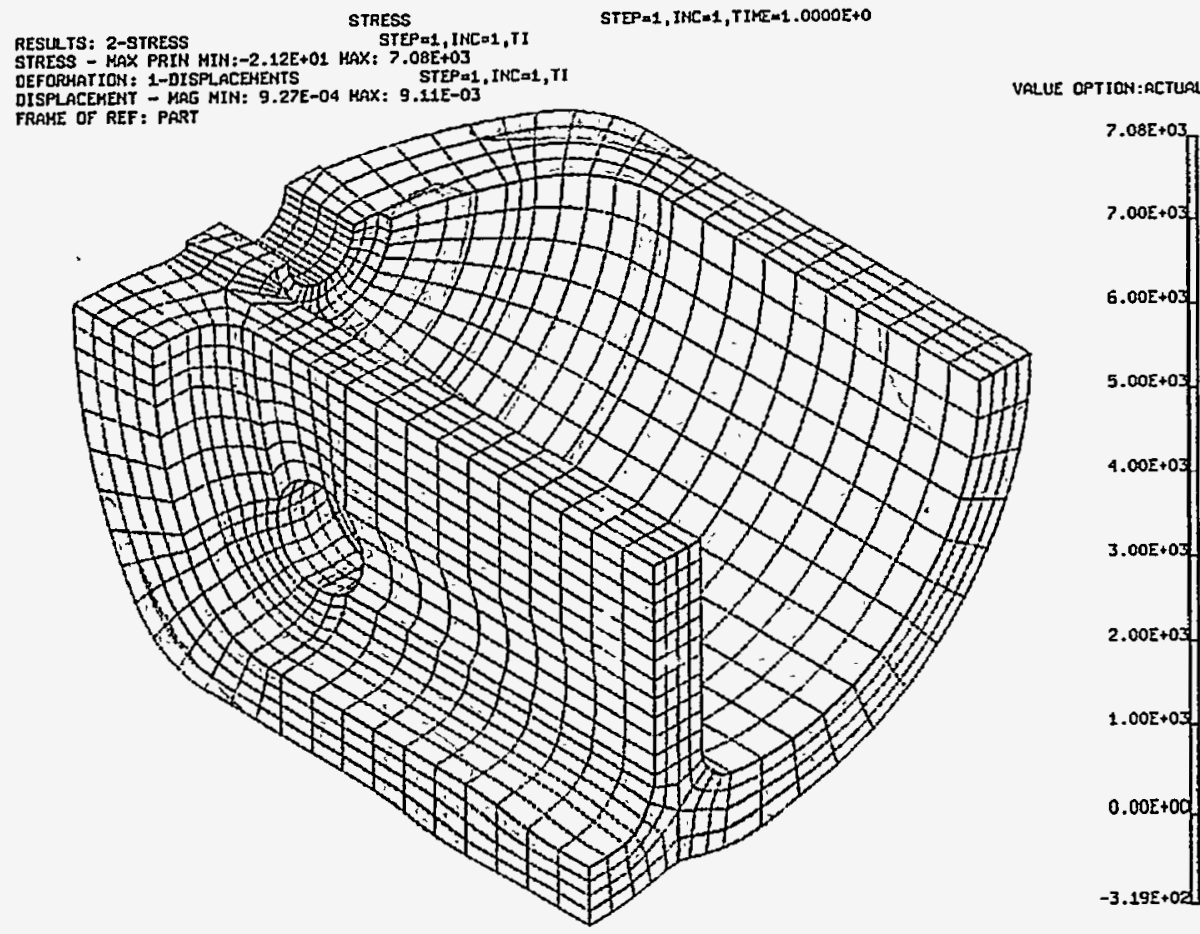

Figure 17, Stress Analysis for Design 2, Inside
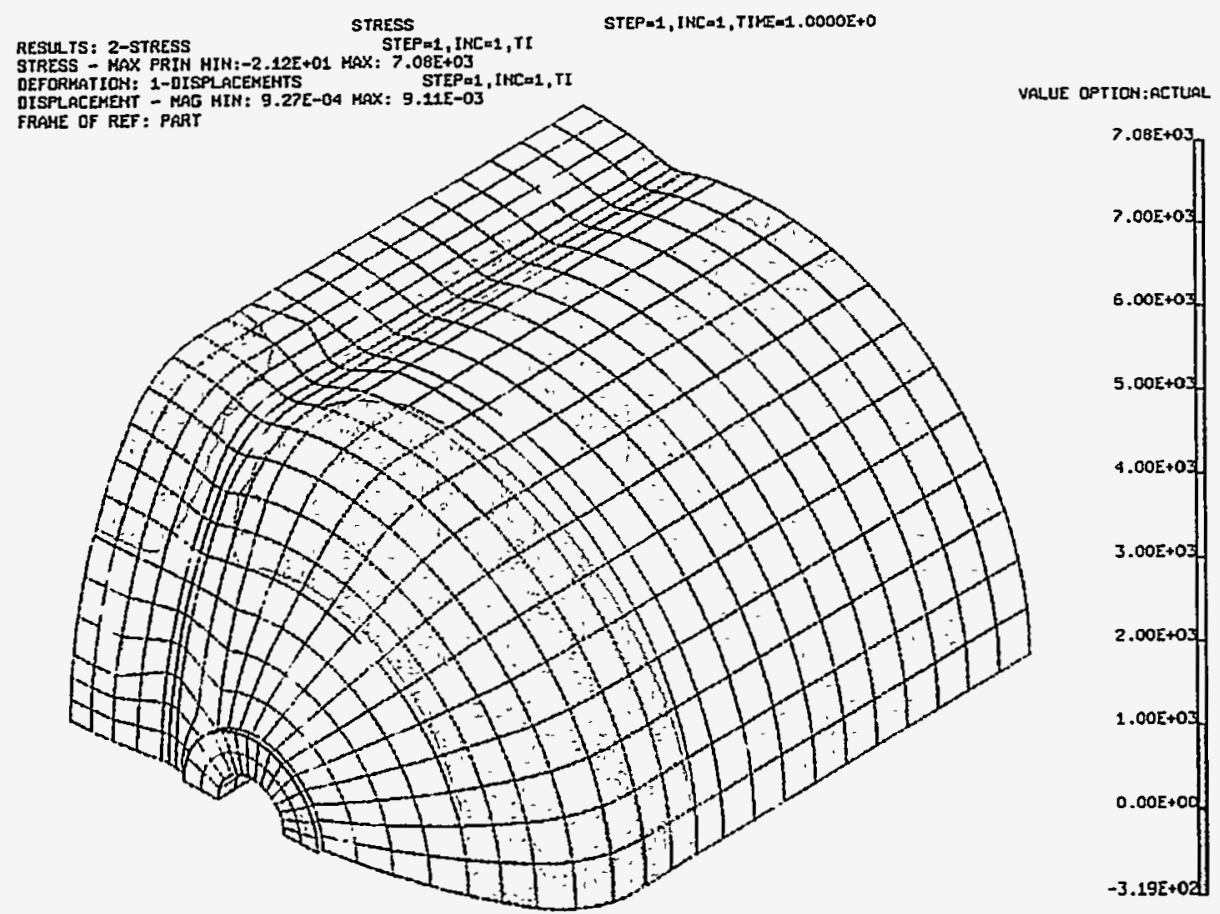

Figure 18, Stress Analysis for Design 2, Outside 

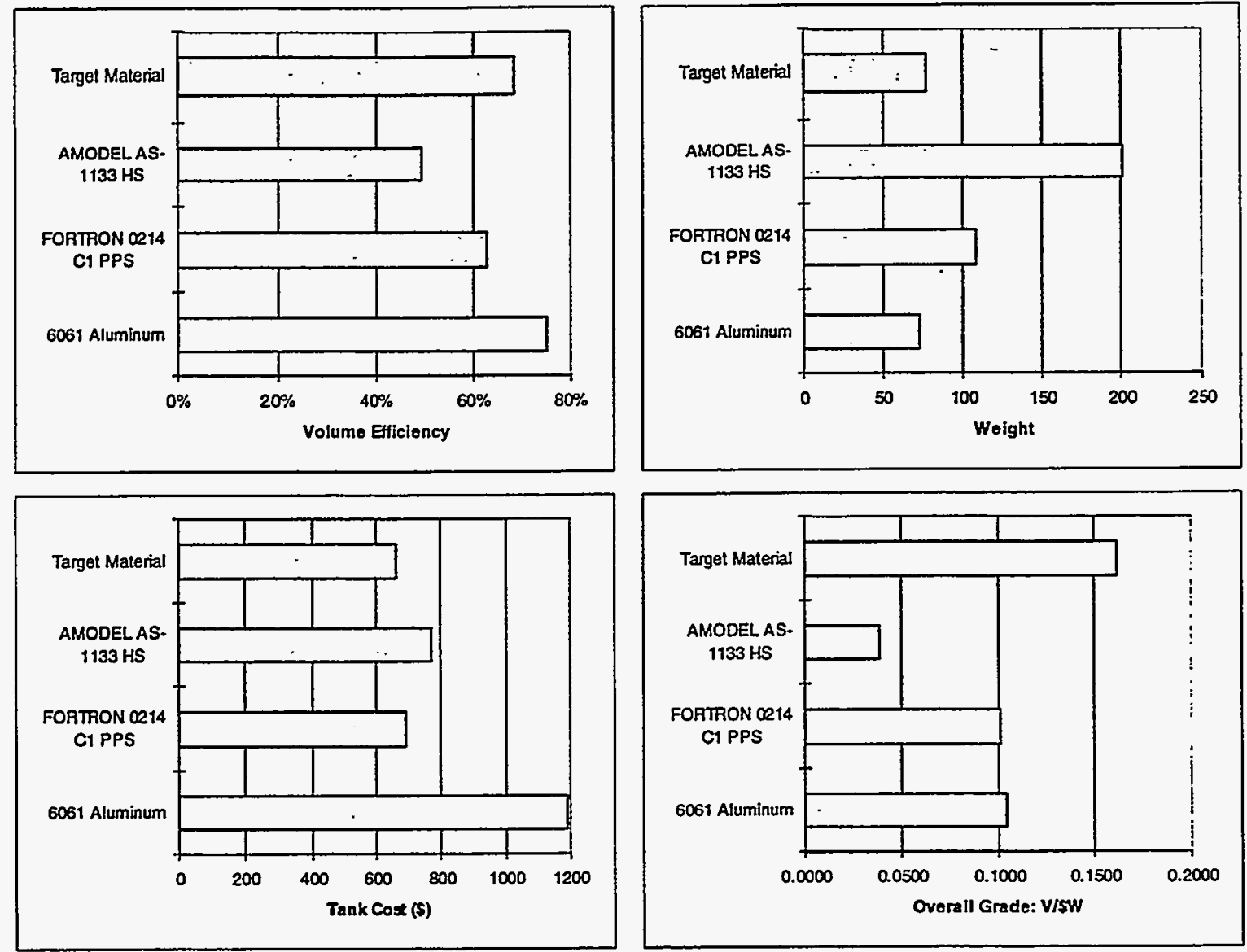

Figure 20, Cost Model Comparisons

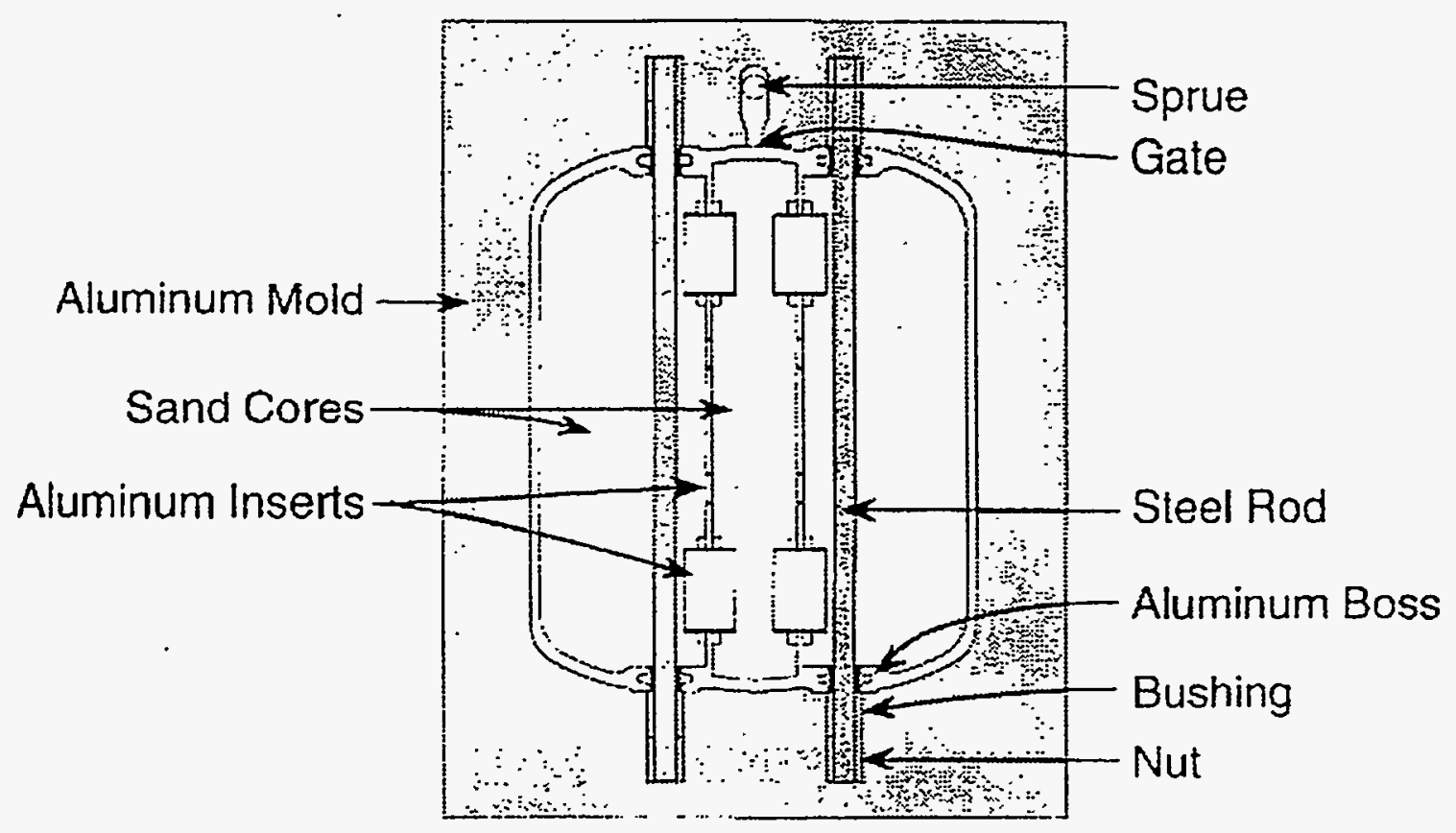

Figure 21, Original Injection Mold 


\section{THTOMOL}

AEROSPACE \& INDUSTFLAL TECHNOLOGIES

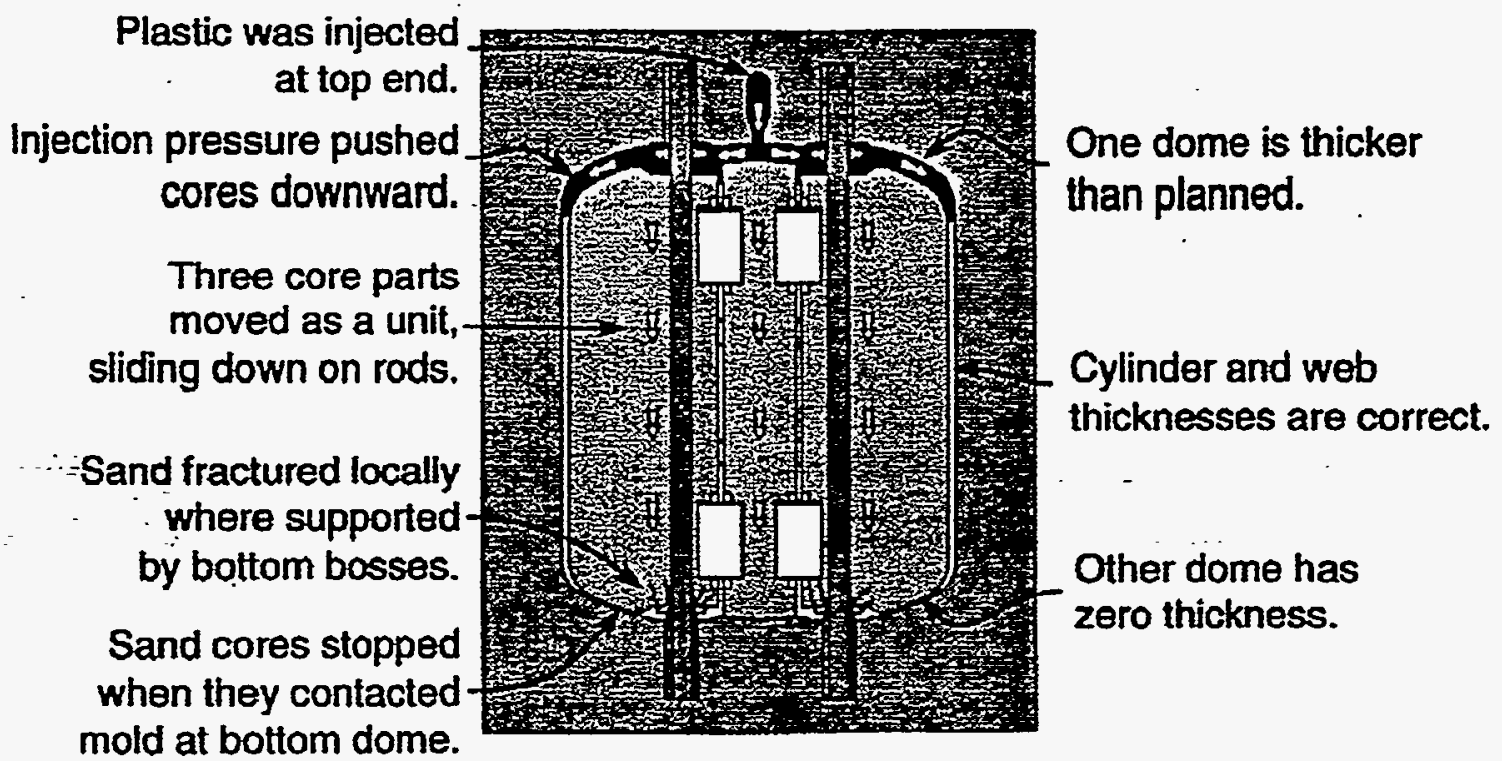

Figure 22, Sand Core Failures

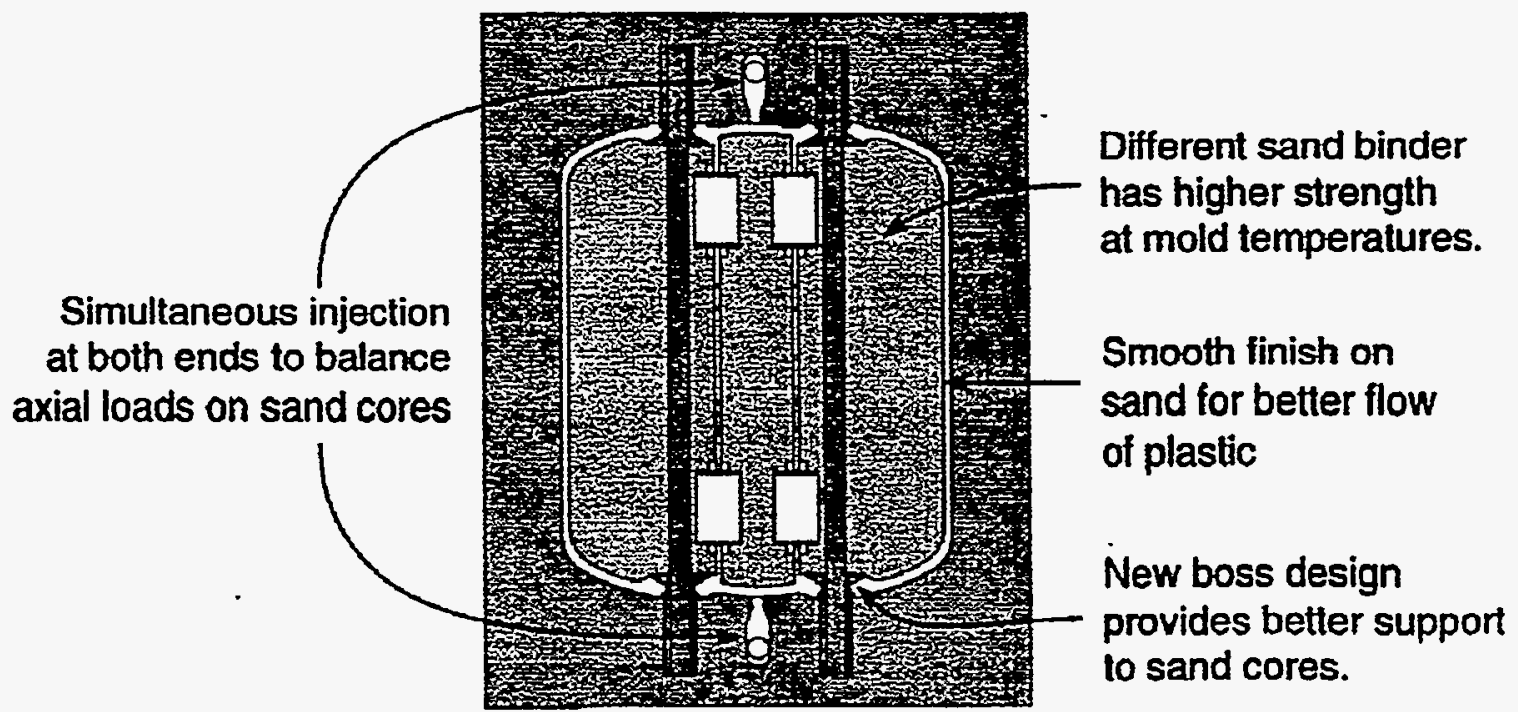

Figure 23, Molding Process Improvements 

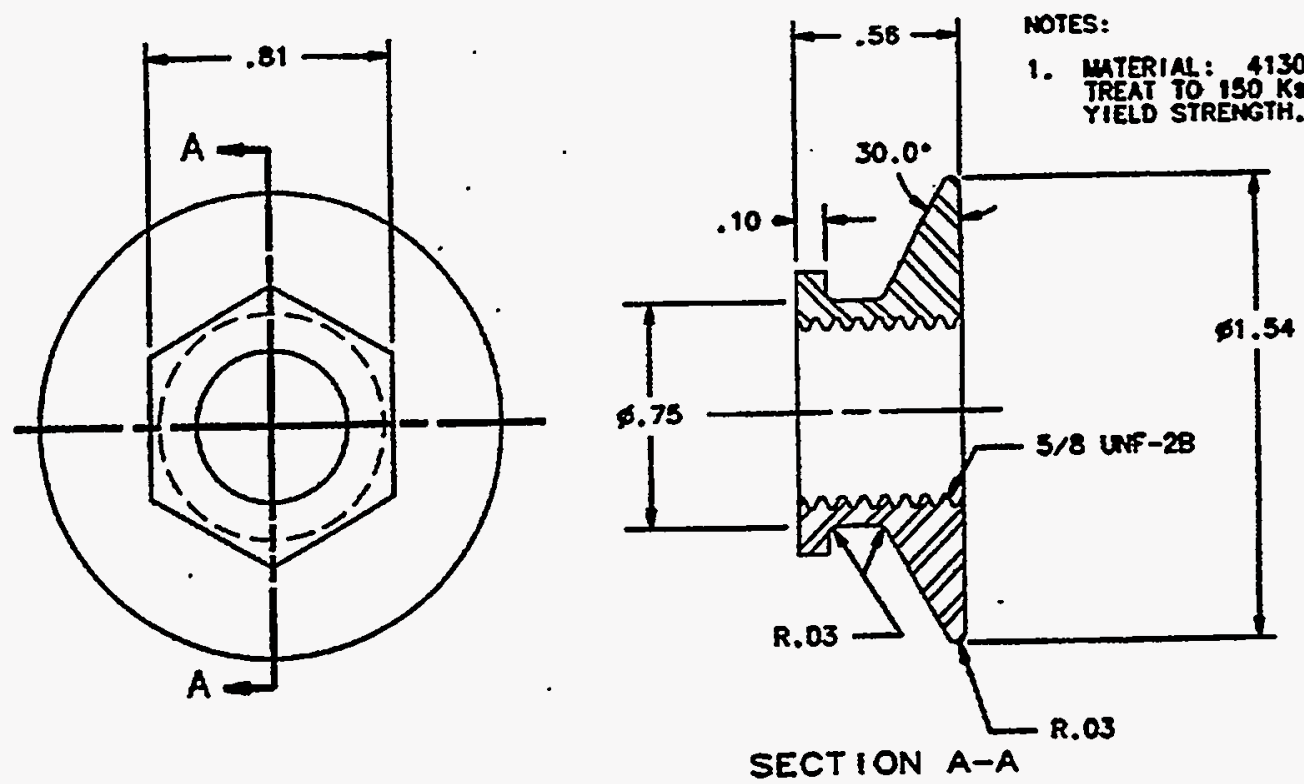

Figure 24, Redesigned Bass 


\section{THIOKOL \\ AEROSPACE \& INDUSTRLAL TECHNOLOGIES}

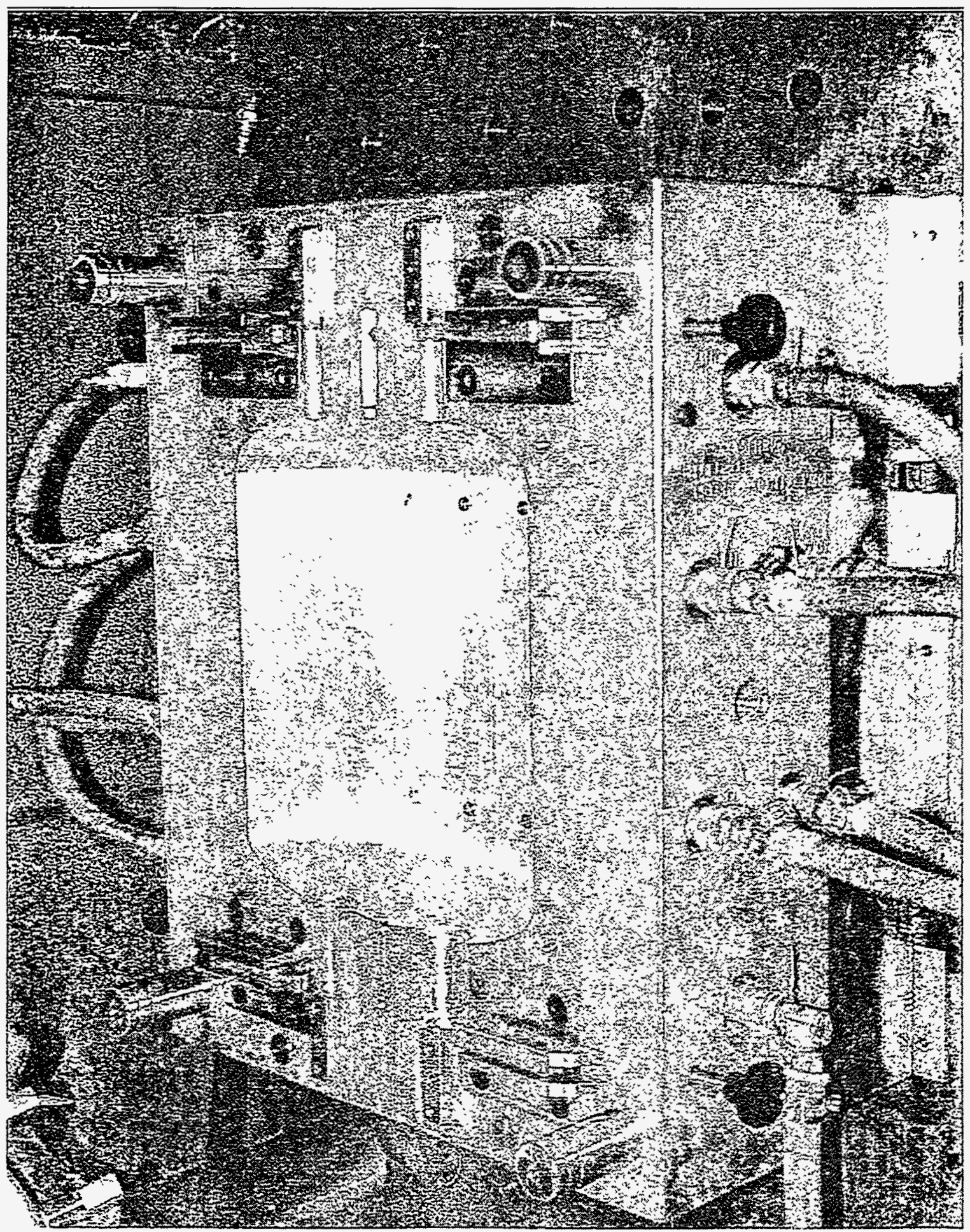

Figure 25, Injection Mold for Subscale Tank 


\section{THIOKOL}

AEROSPACE \& INDUSTRLAL TECHNOLOGIES

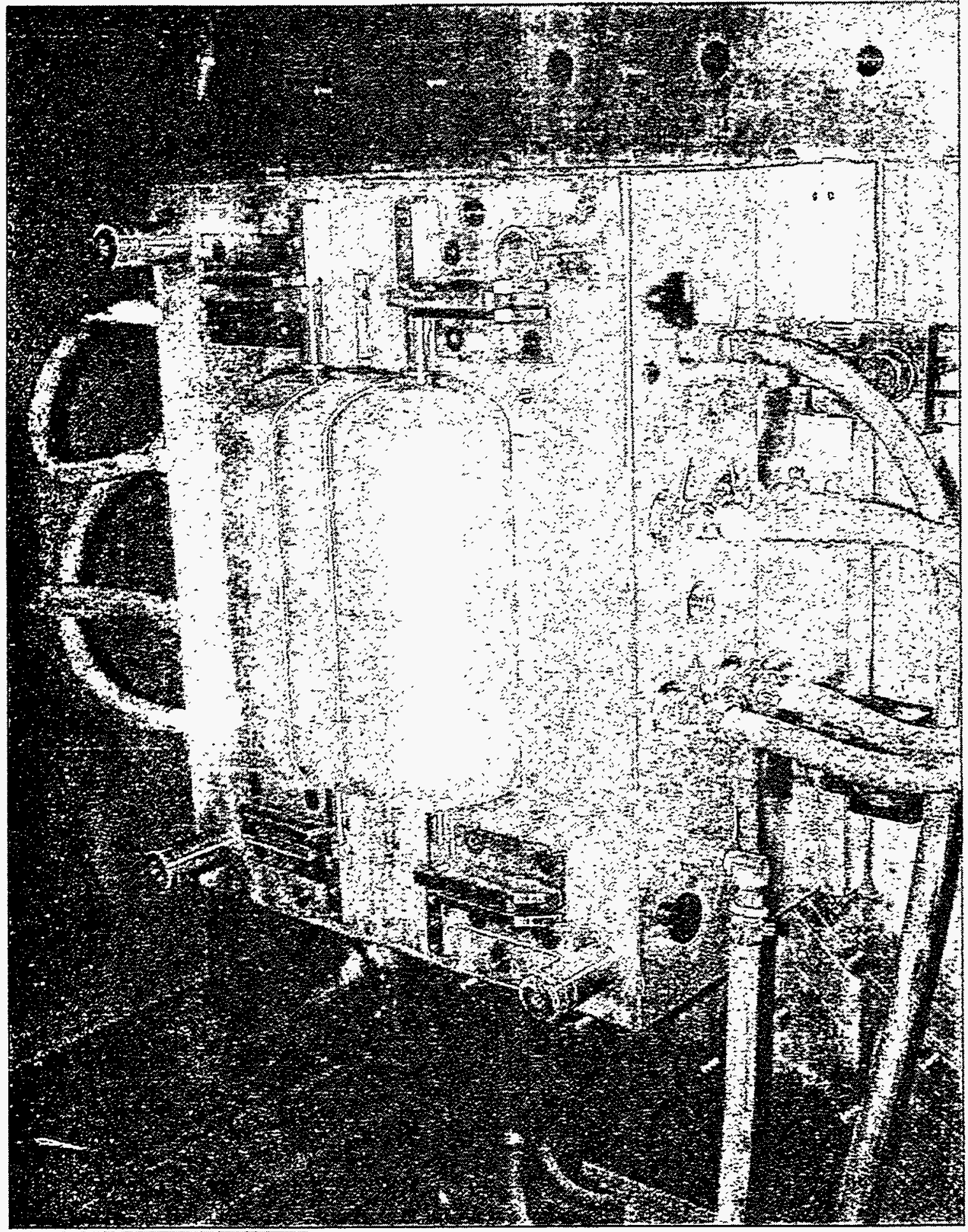

Figure 26, Sand Cores in Injection Mold 


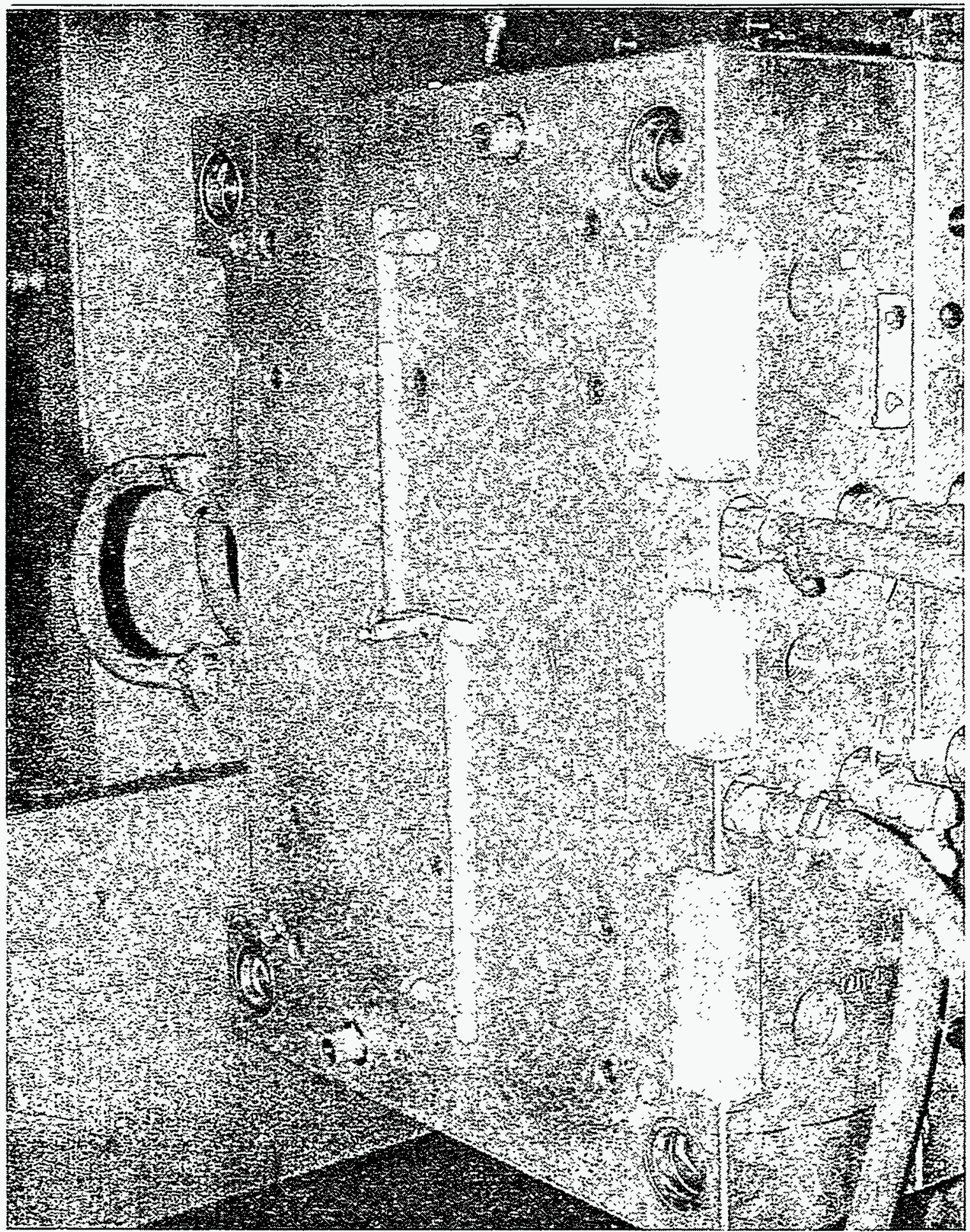

Figure 27, Runner System for Balanced Injection at Both Ends 


\section{THTOMOL}

AEROSPACE \& INDUSTAIAL TECHNOLOGIES

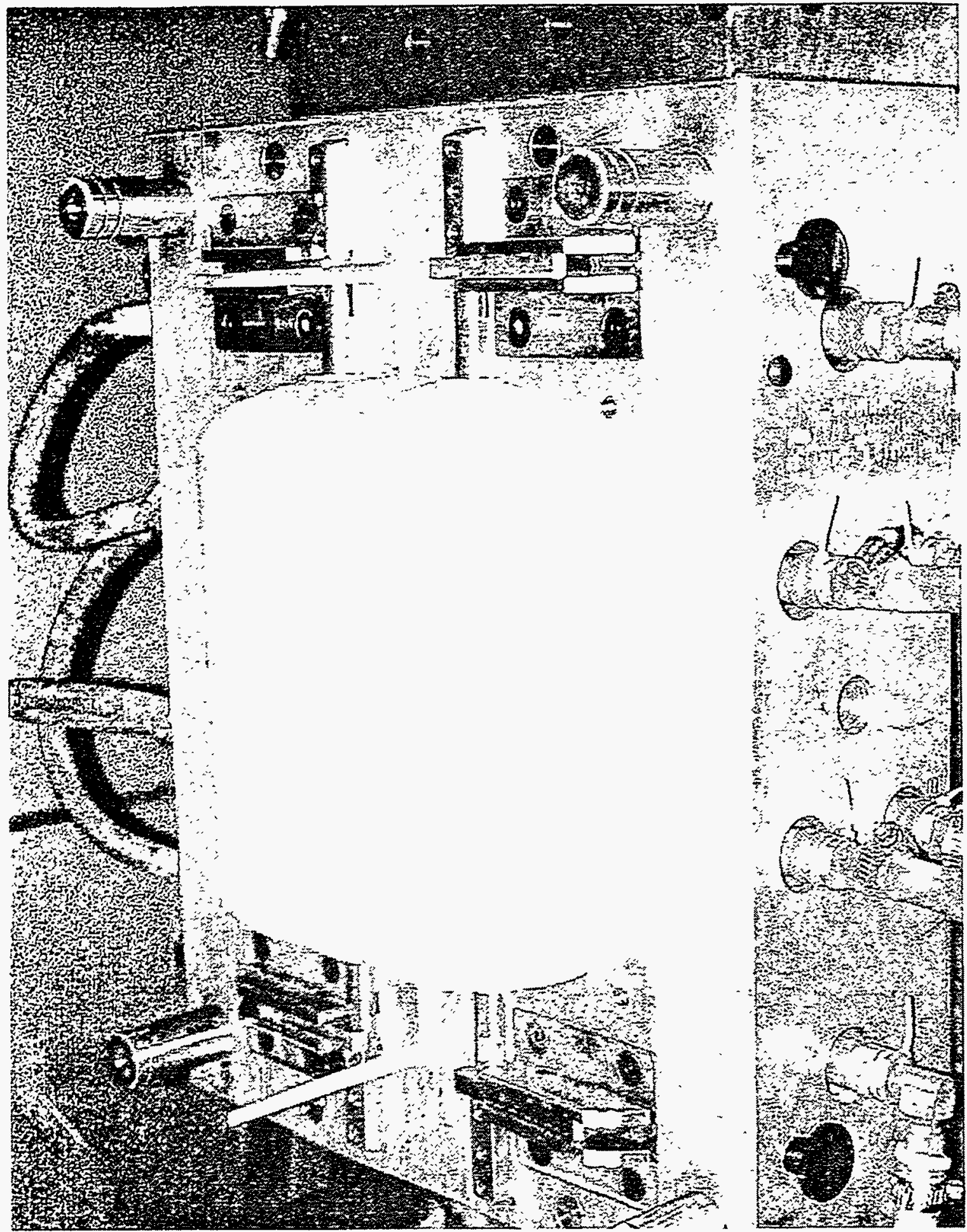

Figure 28, Mold Opened after Molding Part 


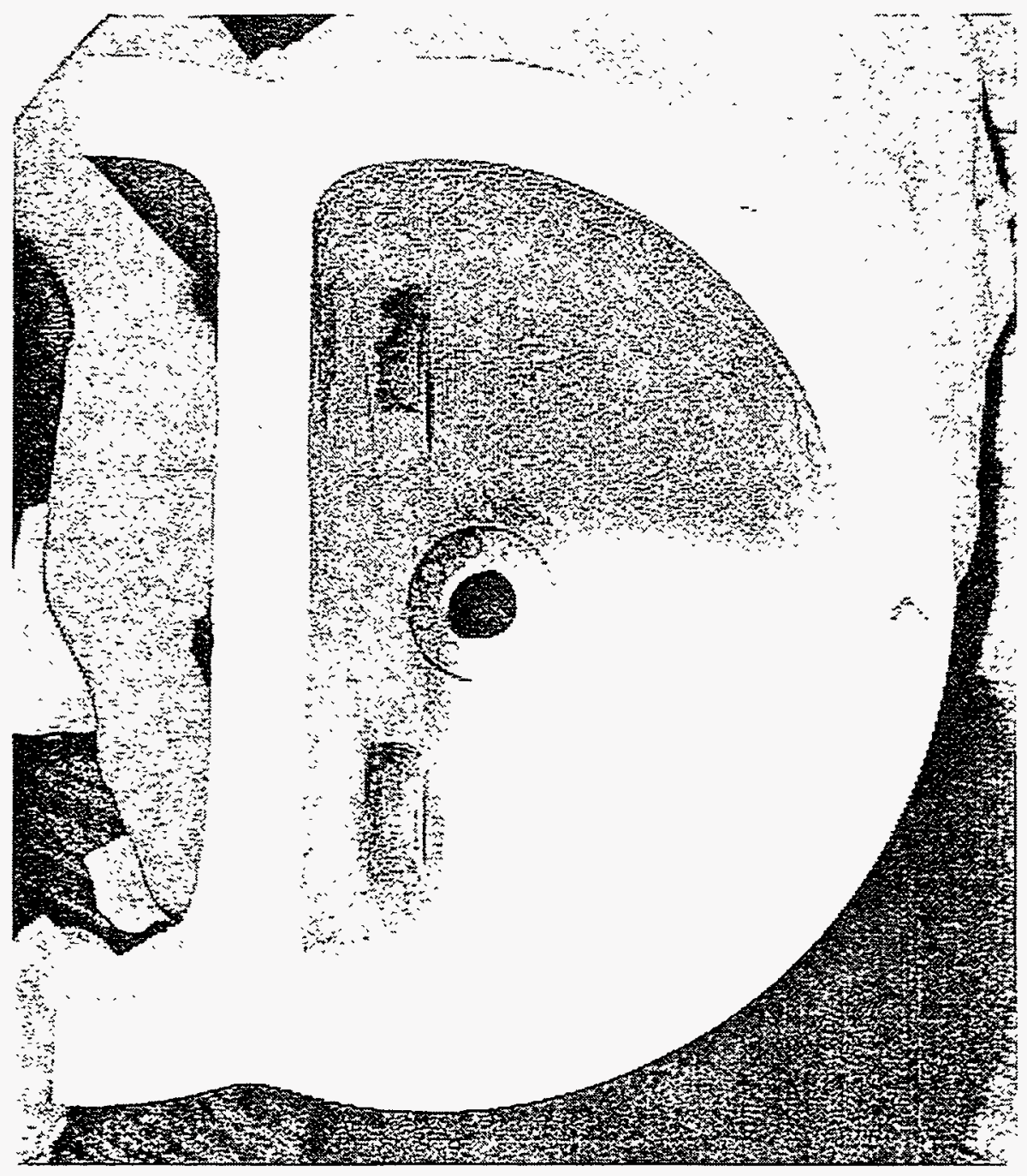

Figure 29, Design 2, Tank \#1, Dissected 


\section{THIOKOL}

AEROSPACE \& INDUSTRIAL TECHNOLOGIES

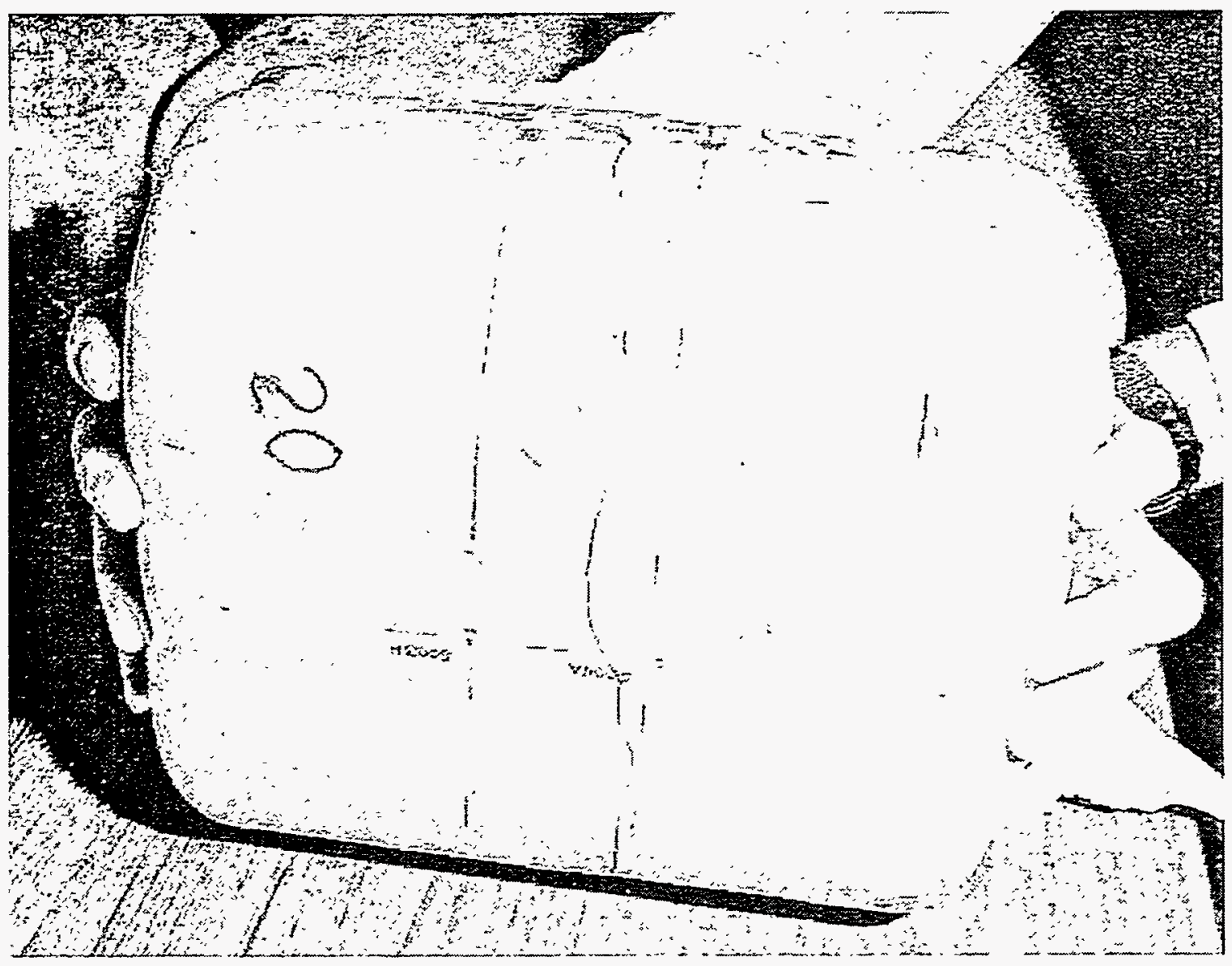

Figure 30, Design 2, Tank \#20, After Burst Test

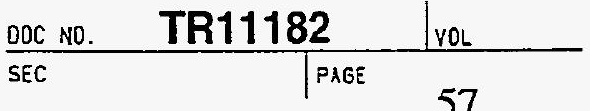




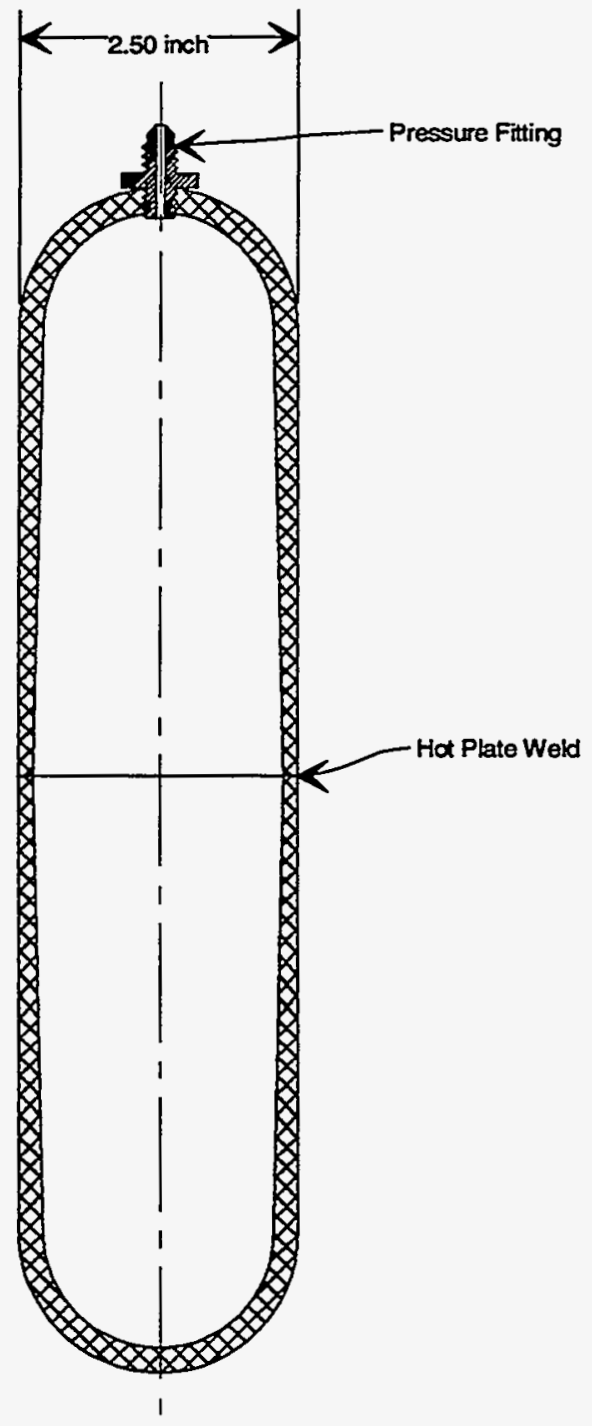

Figure 31, Welded Bottle Test 
Wolded Bottle vs Tube Bursts

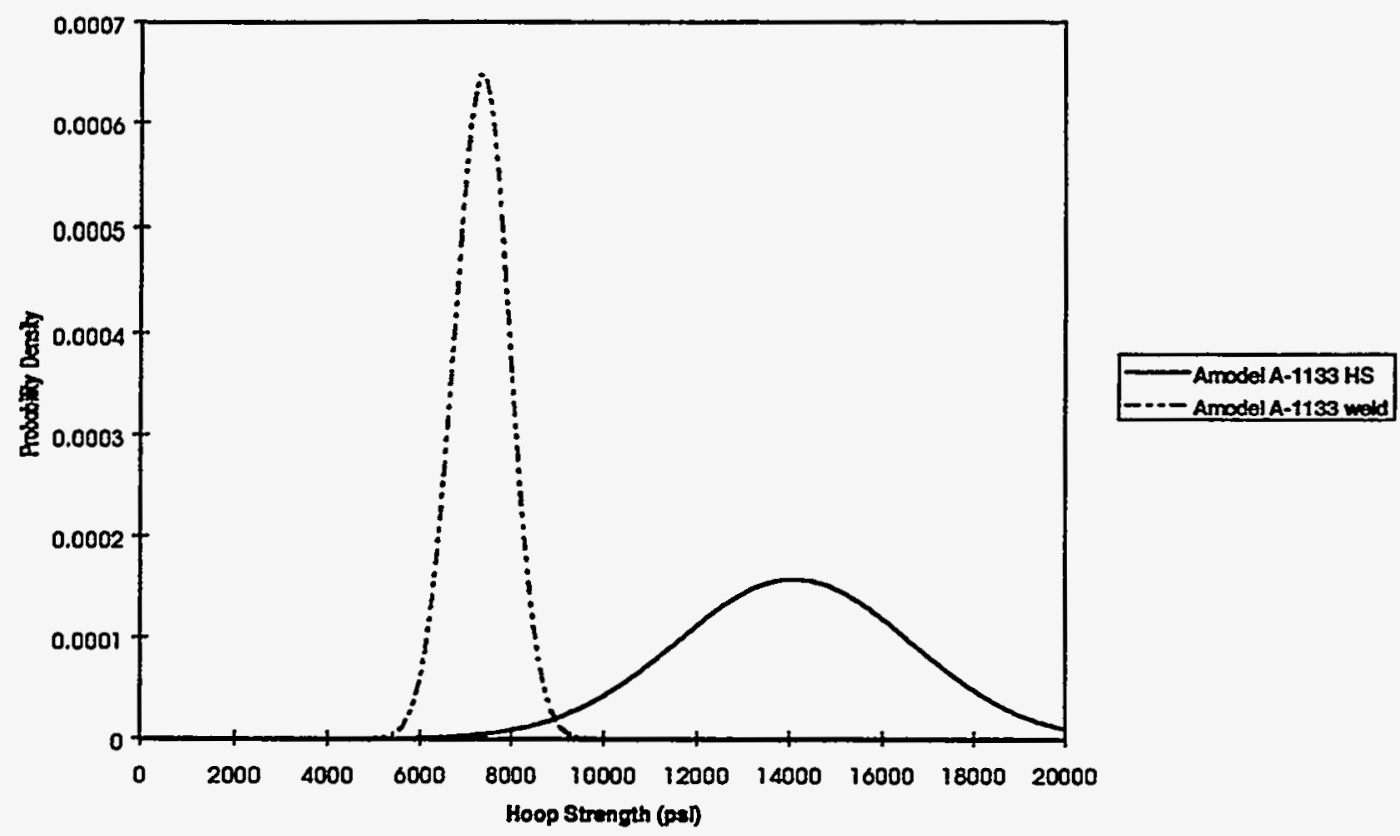

Figure 32, Weld Tests for AMODEL A-1133 HS

Weided Bottle v8 Tube Bursts

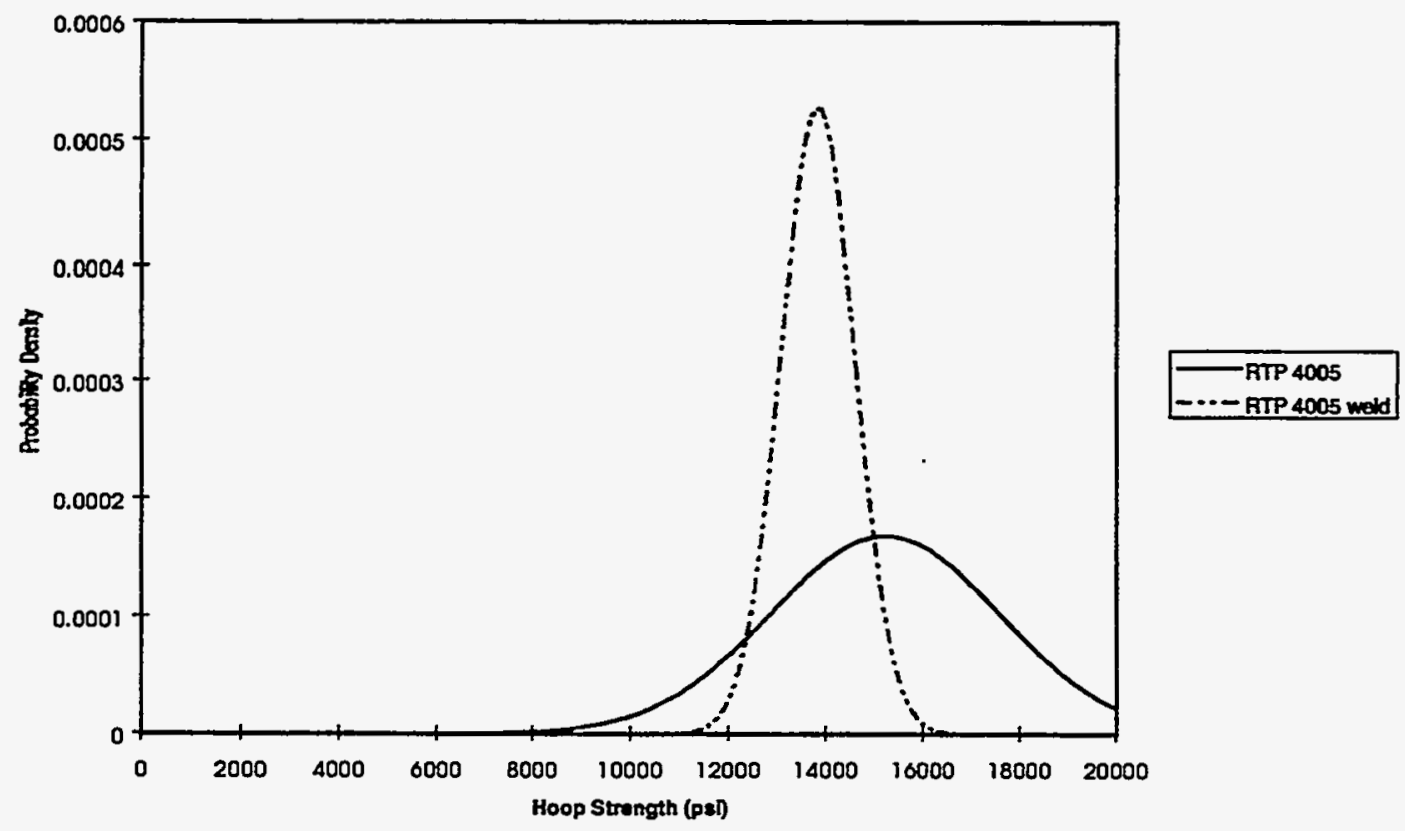

Figure 33, Weld Tests for RTP 4005 VoL 


\section{THIOKOL \\ AEROSPACE \& INDUSTRIAL TECHNOLOGIES}

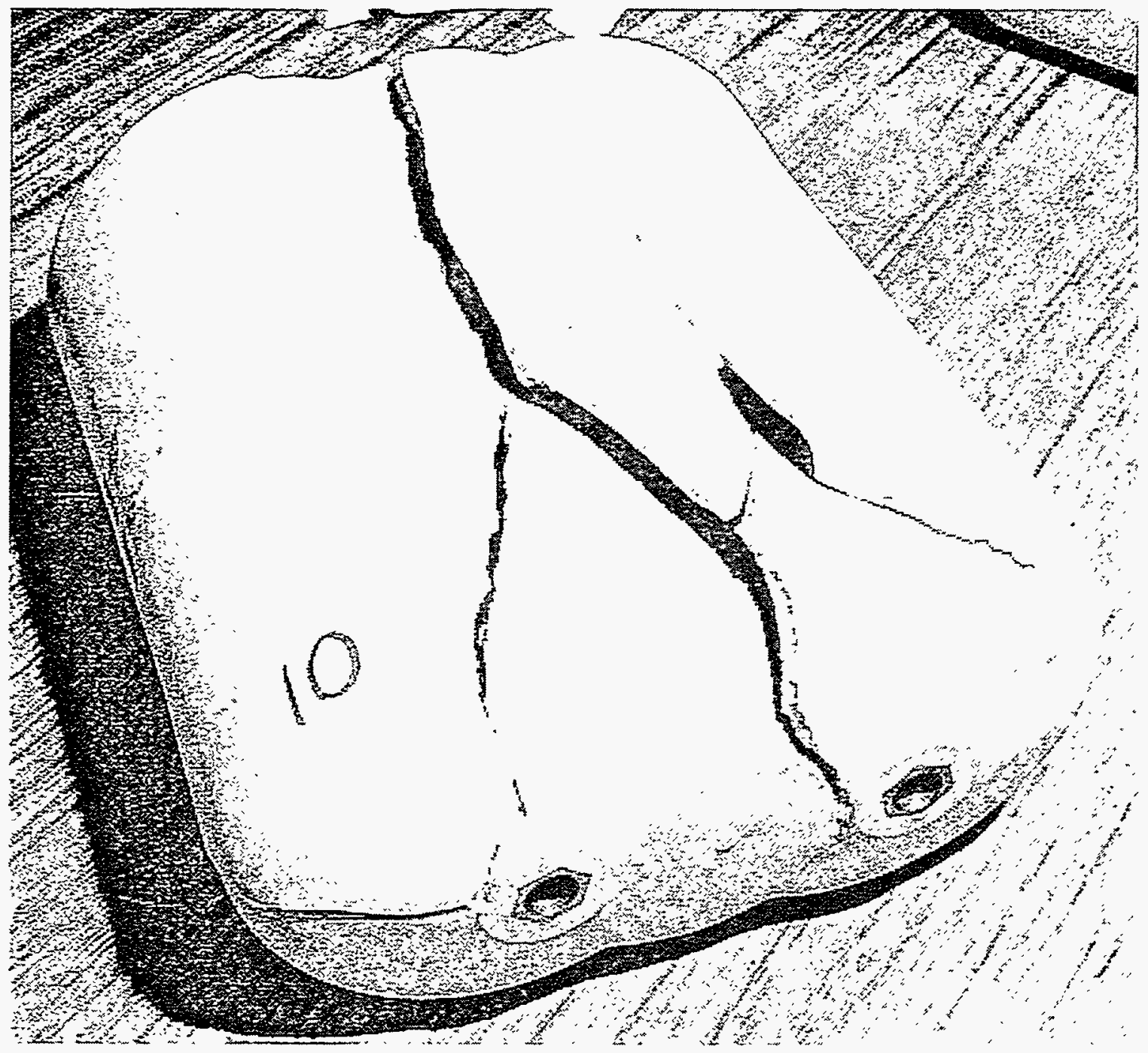

Figure 34, Design 1, Tank \#10, After Burst Test 


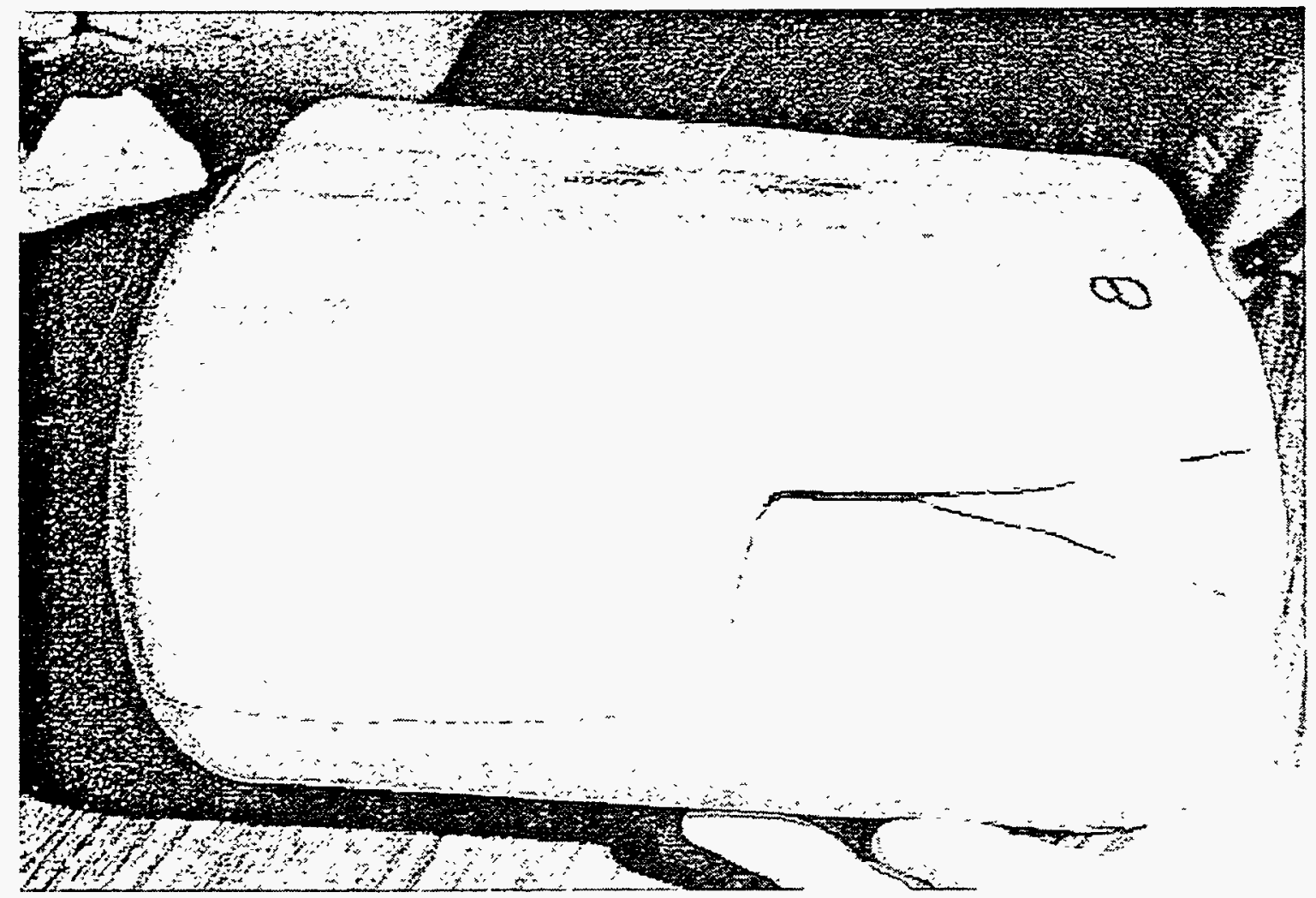

Figure 35, Design 1, Tank \#8, After Burst Test 


\section{THIOKOL}

AEROSPACE \& INDUSTRLAL TECHNOLOGIES

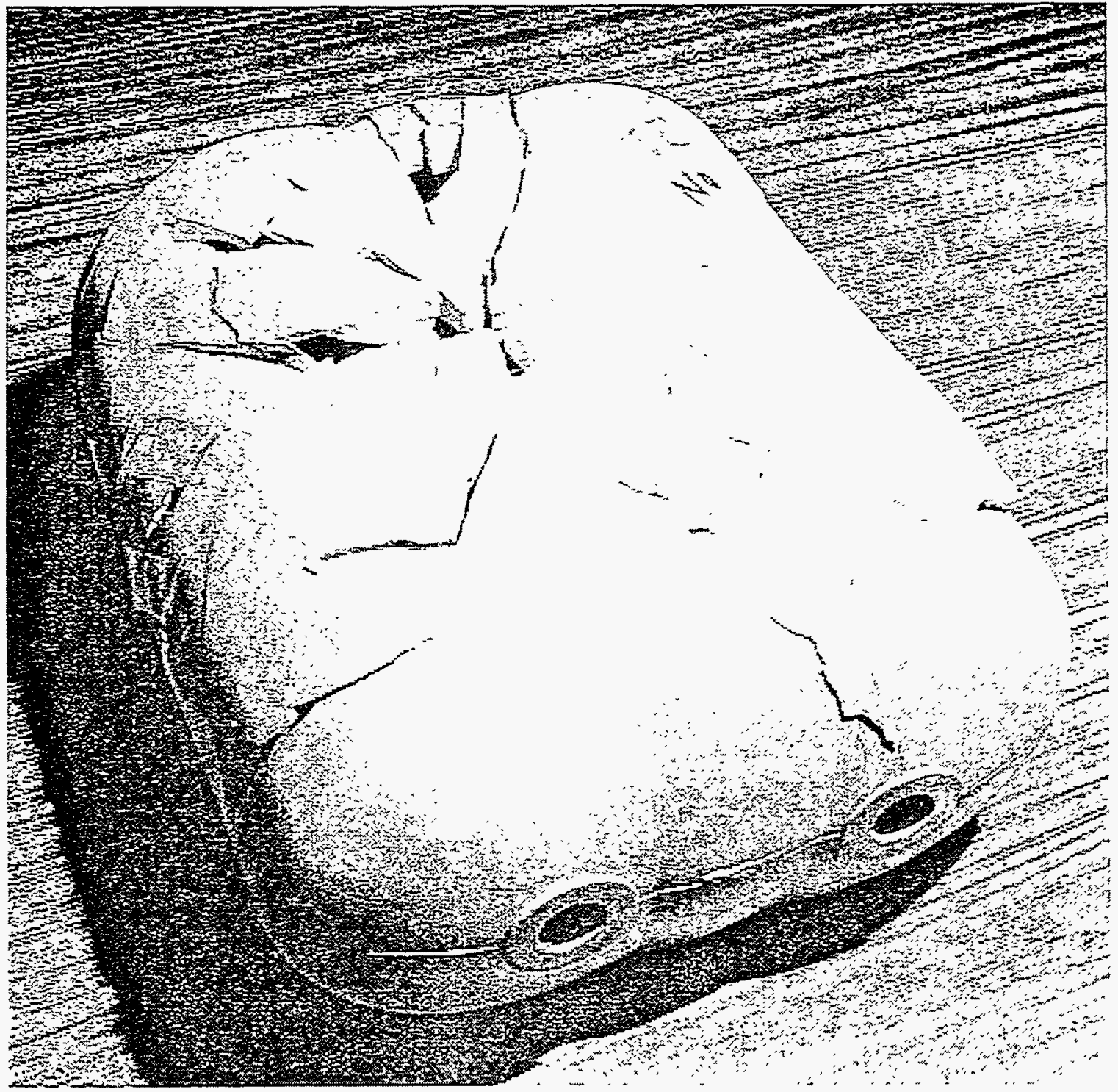

Figure 36, Design 2, Tank $\stackrel{421}{=2}$, Reassembled After Burst Test 


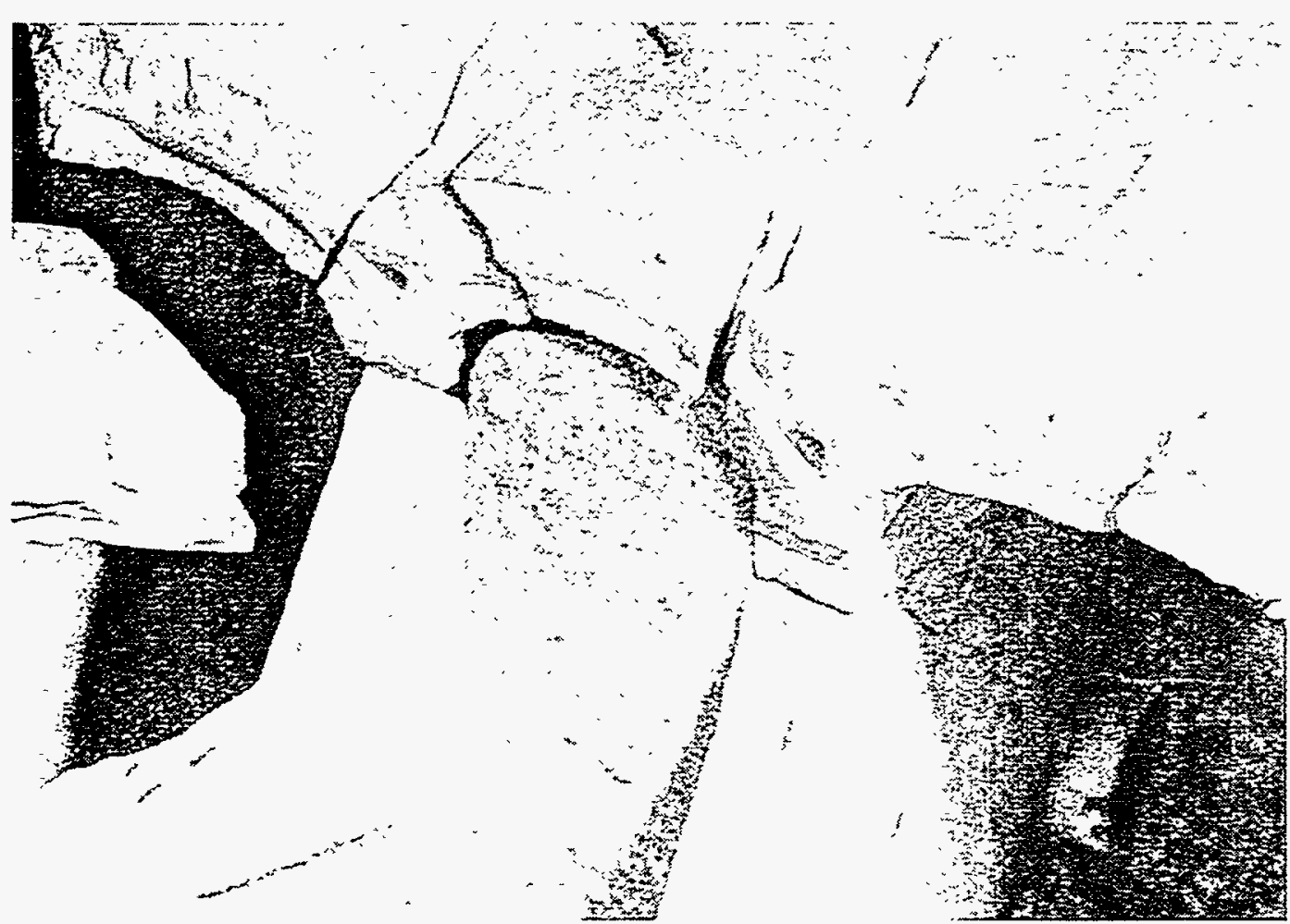

Figure 37, Design 2, Tank $\# 2$, Weld Line Fracture 


\section{THIOKOL}

AEROSPACE \& INOUSTRLAL TECHNOLOGIES

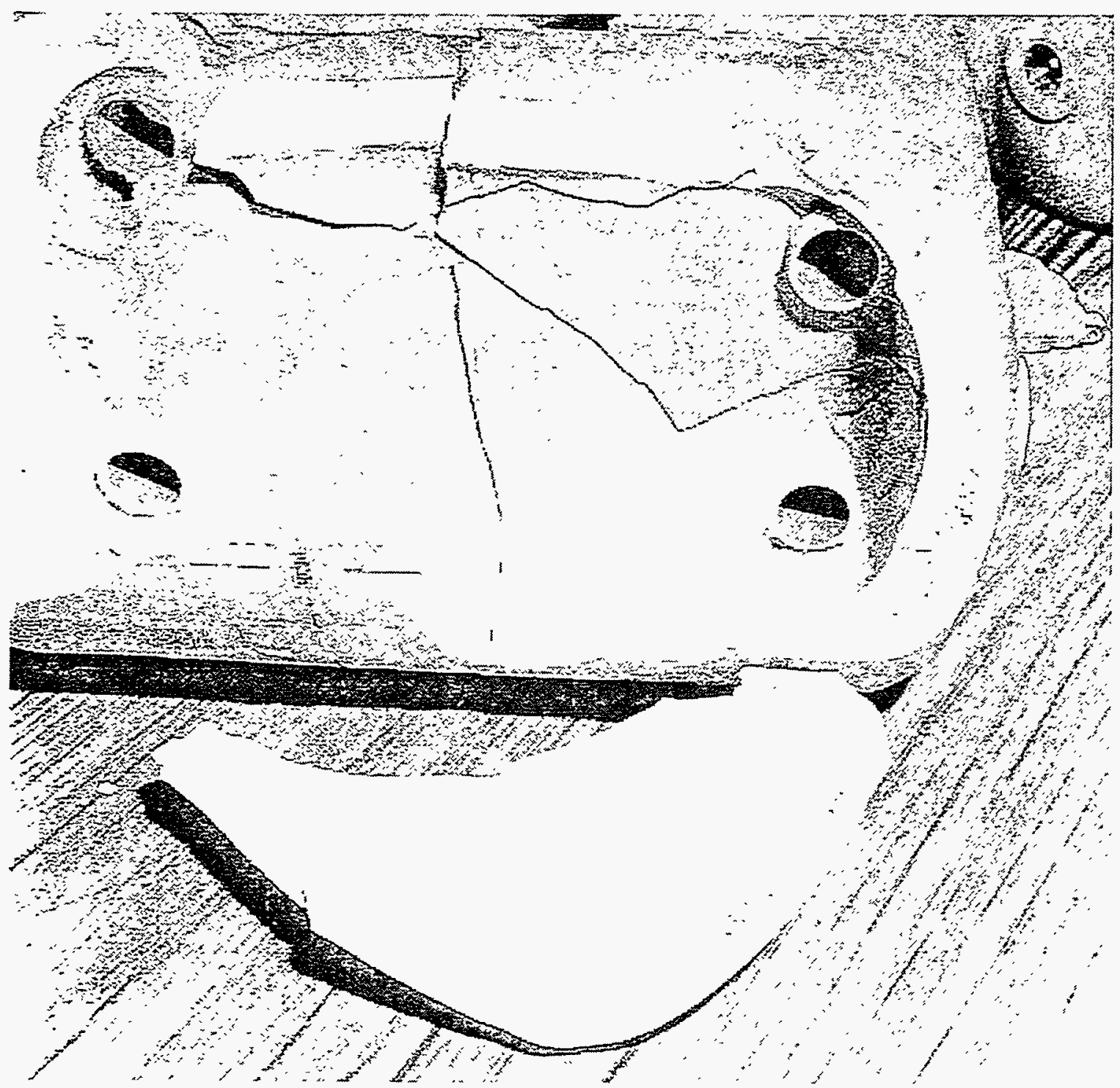

Figure 38, Design 2, Tank $\$ 20$, After Burst Test 


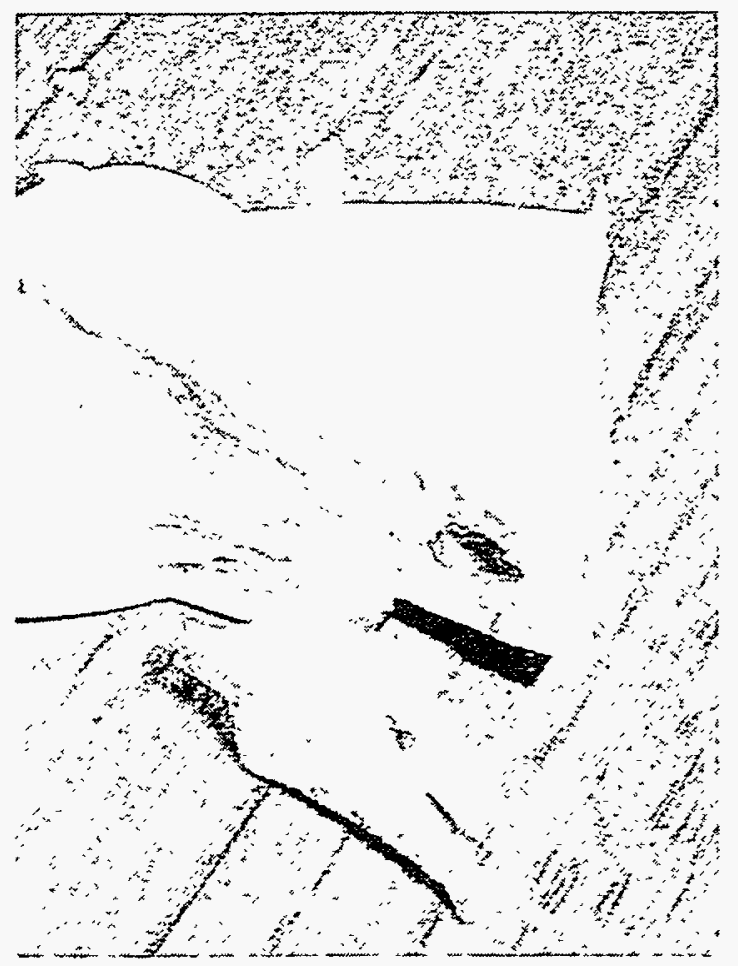

Figure 39, Design 2, Tank \#21, Void Near Weld Line

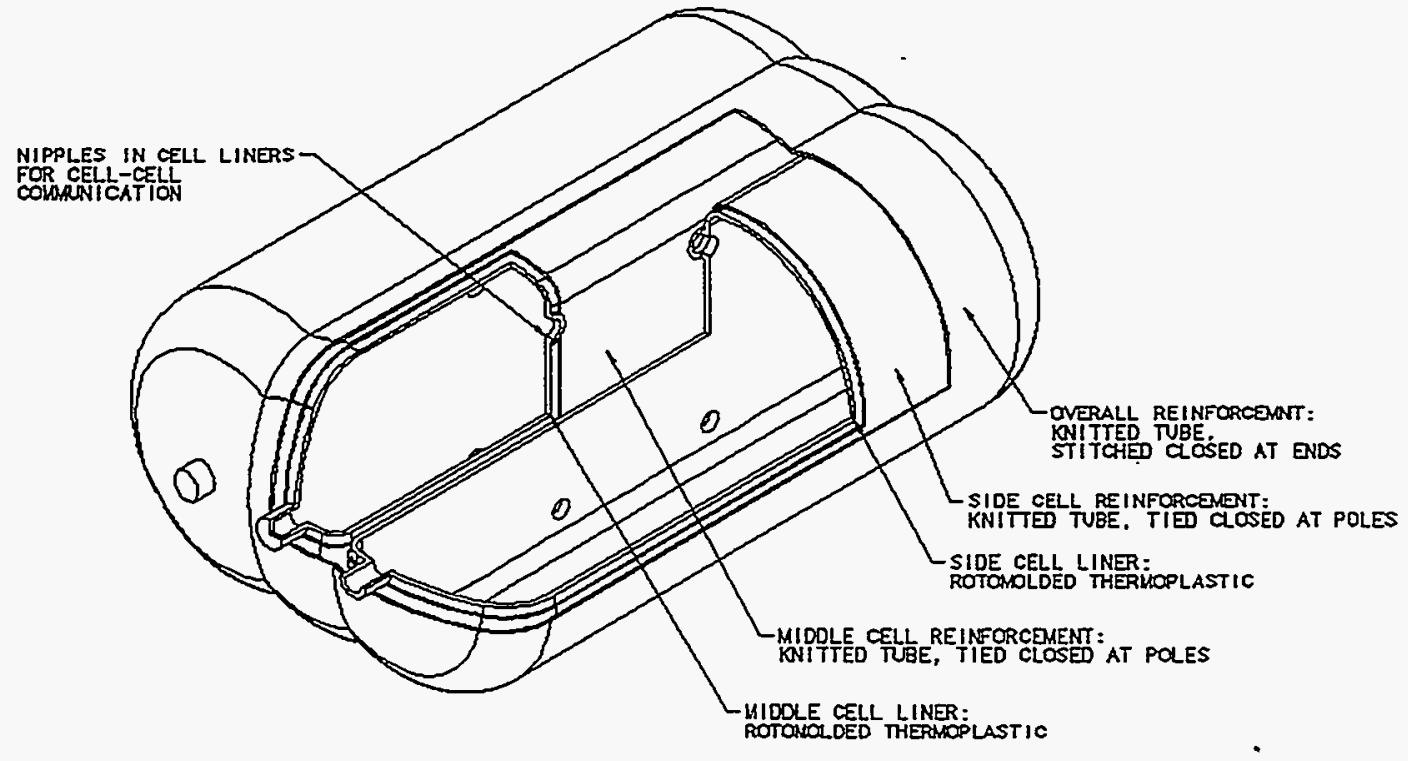

Figure 40, Design for SRIM Molding 


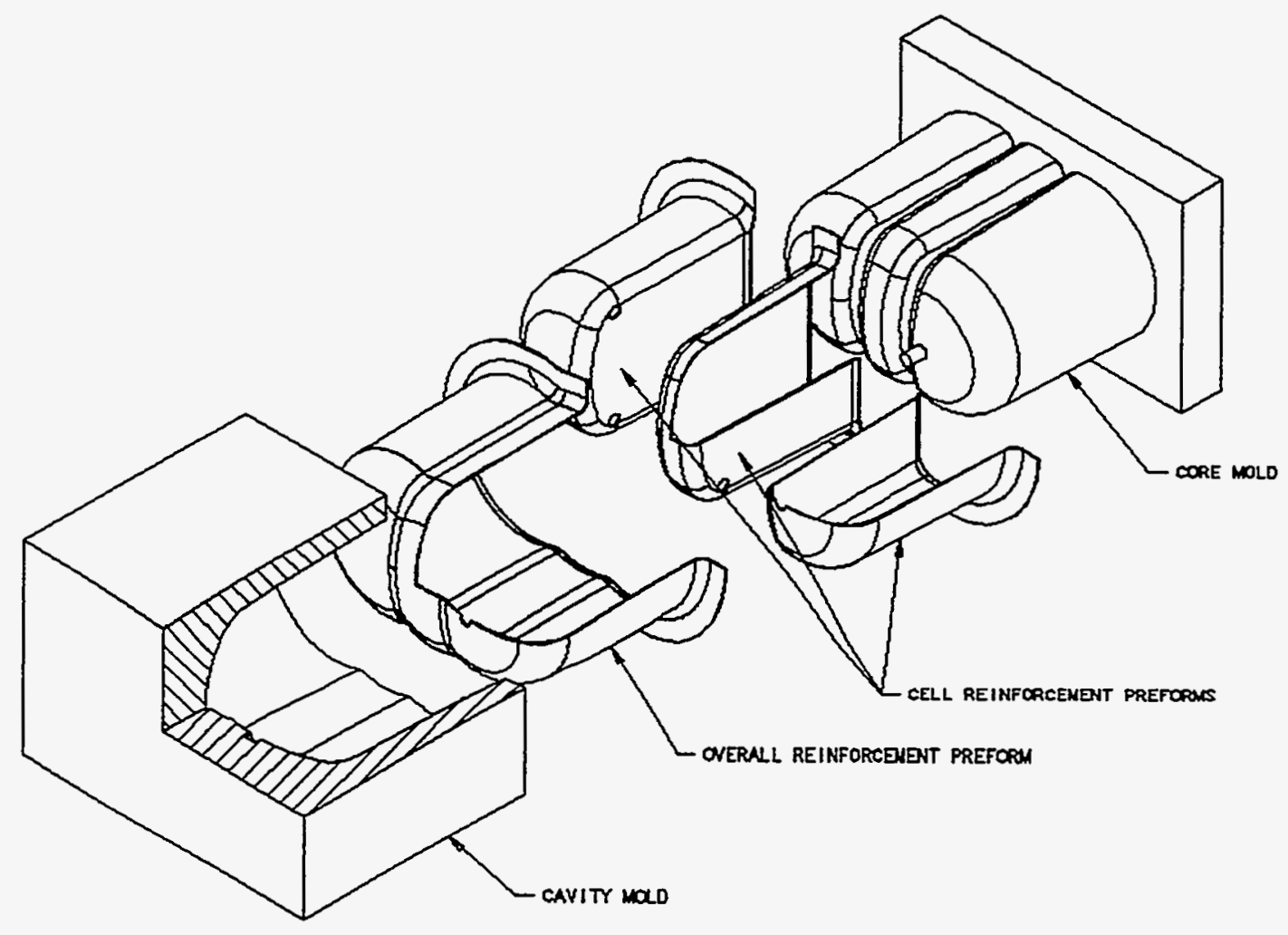

Figure 41, Fabric Reinforced Thermoplastic Injection Molding

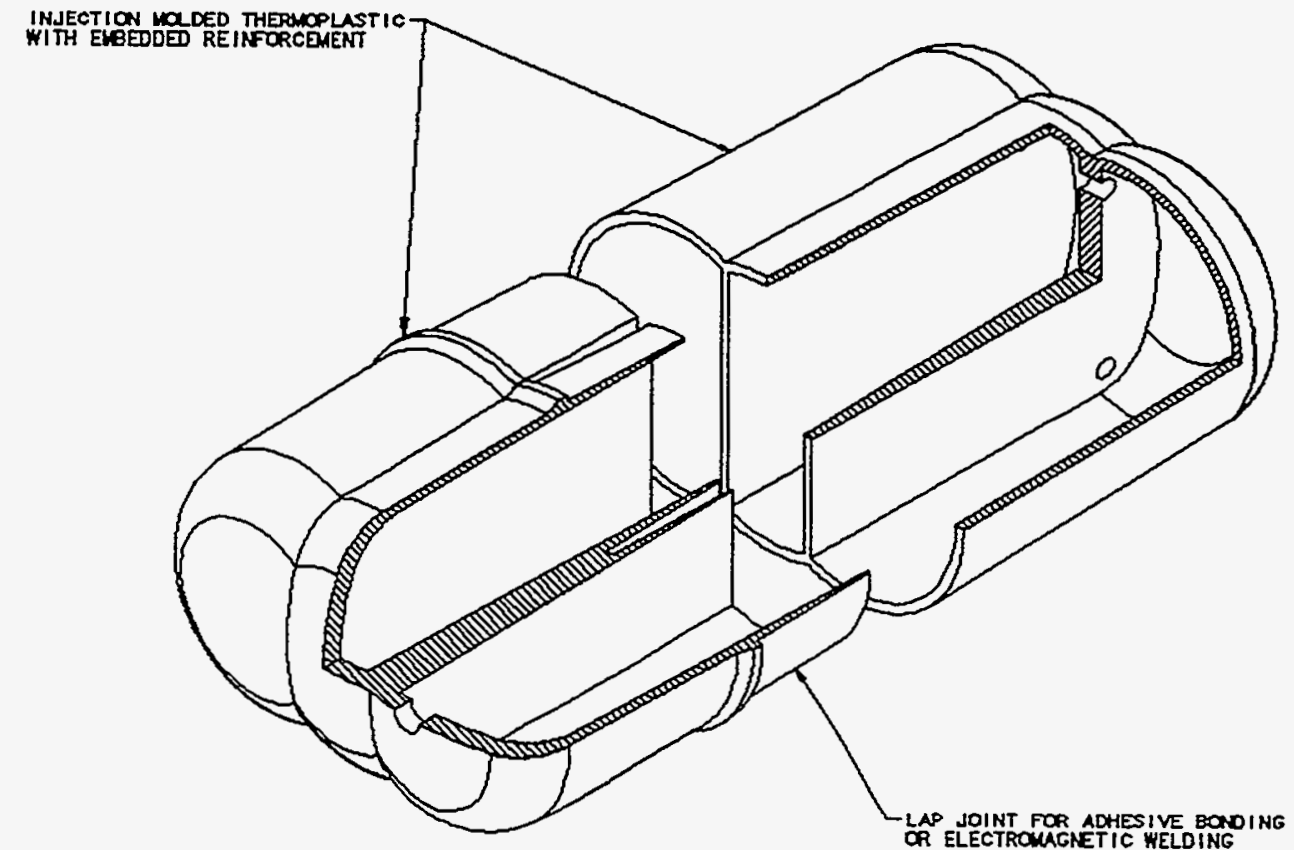

Figure 42, Lap Joint for Joining Tank Halves 


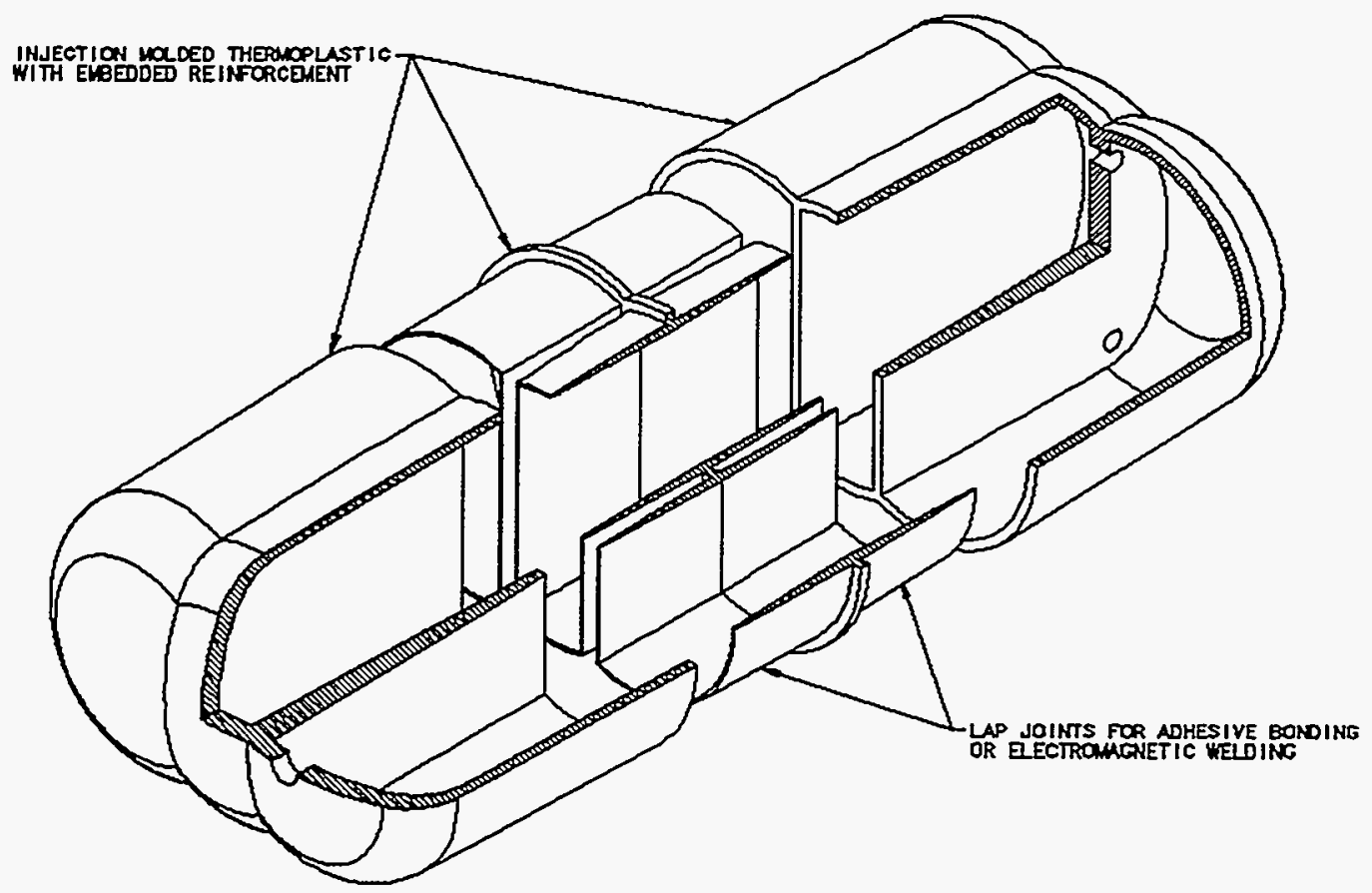

Figure 43, Double Lap Joint for Joining Tank Halves

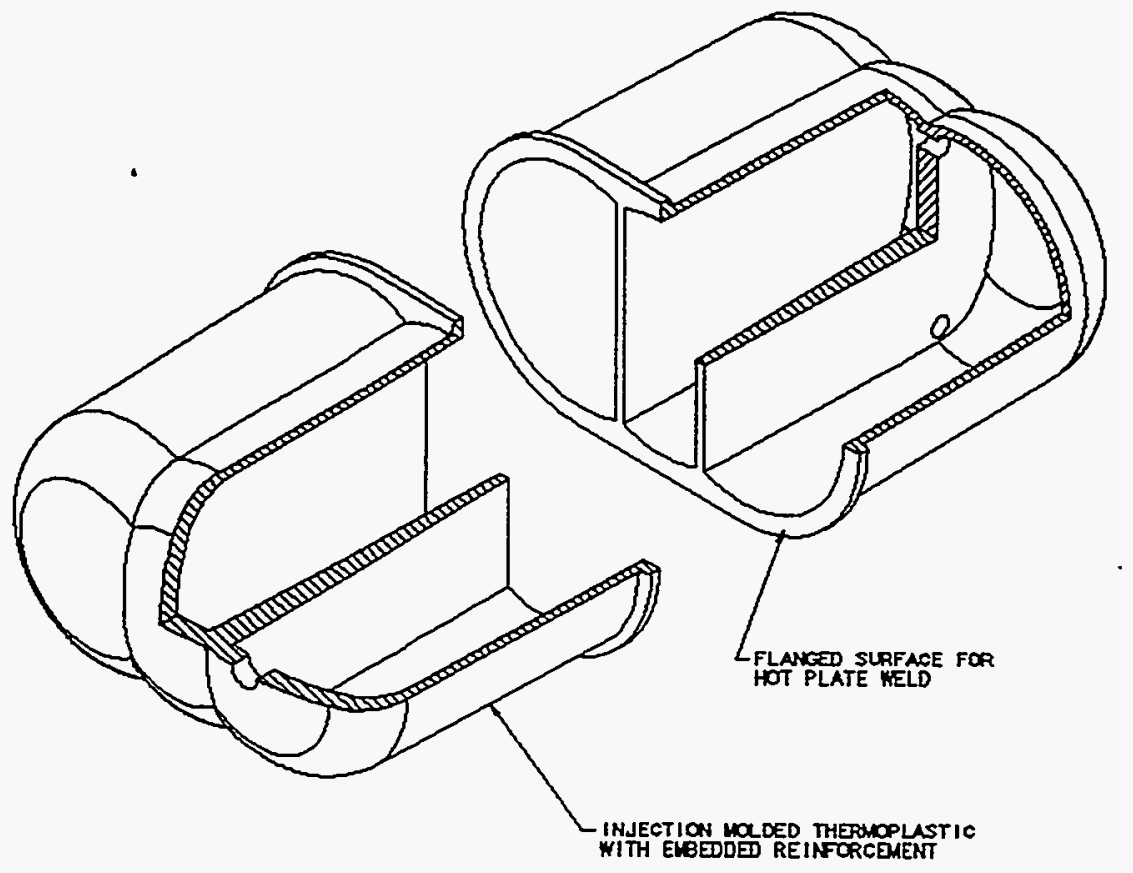

Figure 44, Butt Joint for Joining Tank Halves 
 \\ AEROSPACE \& INDUSTRIAL TECHNOLOGIES}

\section{DISTRIBUTION}

$\underline{\text { Recipient }}$

Bob Graham

Rick Golde

Fred DuVall

Michael Blair

Richard Kunz

Mark Warner

David Son

George Berkley

NREL; Bill Warnock

NREL; Renee Howard

Brookhaven; Jim Wegrzyn

Hettinga; Siebolt Hettinga
Mail Stop

254

230

230

230

254

254

254

252 


\section{REPORT DOCUMENTATION PAGE}

blic reporting burden for this collection of information is estimated to average 1 hour per response, including the time for reviewing instructions, searching existing data sources, thering and maintaining the data needed, and completing and reviewing the collection of information. Send comments regarding this burden estimate or any other aspect of this illection of information, Including suggestions for reducing this burden, to Washington Headquarters Services, Directorate for Information Operations and Reports, 1215 Jefferson 3vis Highway. Suite 1204. Arlington. VA 22202-4302, and to the Office of Management and Budget, Paperwork Reduction Project (0704-0188). Washington. DC 20503.

\begin{tabular}{l|l|l}
\hline AGENCY USE ONLY (Leave blank) & $\begin{array}{l}\text { 2. REPORT DATE } \\
\text { January 1998 }\end{array}$ & $\begin{array}{l}\text { 3. REPORT TYPE AND DATES COVERED } \\
\text { Subcontract report }\end{array}$ \\
\hline
\end{tabular}

TITLE AND SUBTITLE

5. FUNDING NUMBERS

ww-Cost Conformable Storage to Maximize Vehicle Range

(C) YCF-5-14050-02

(TA) FU702130

AUTHOR(S)

P. Graham

PERFORMING ORGANIZATION NAME(S) AND ADDRESS(ES)

iokol Aerospace \& Industrial Technologies

O. Box 707

igham City, UT 84302-0707

SPONSORING/MONITORING AGENCY NAME(S) AND ADDRESS(ES)

ational Renewable Energy Laboratory

317 Cole Boulevard

olden, CO 80401-3393

8. PERFORMING ORGANIZATION REPORT NUMBER

\section{. SUPPLEMENTARY NOTES}

\section{!a. DISTRIBUTION/AVAILABILITY STATEMENT}

ational Technical Information Service

S. Department of Commerce

!85 Port Royal Road

Jringfield, VA 22161 12b. DISTRIBUTION CODE

UC-1504

1. ABSTRACT (Maximum 200 words) Although liquefied petroleum gas and compressed natural gas are attractive contenders for converting vehicles from gasoline and esel to altemative fuels, two factors inhibit conversion: additional vehicle costs and reduced range compared to gasoline. In overcoming these barriers, a key element the alternative fuel system becomes the storage tank for these pressurized fuels. Thiokol Corporation has developed and is now producing a conformable aluminum rage system for liquefied petroleum gas, which increases the fuel storage in a given rectangular envelope. This project's goal was to develop the technology for a nilar conformable tank made of injection-molded plastic to decrease costs.

\section{SUBJECT TERMS}

ternative fuels, liquefied petroleum gas and compressed natural gas storage, pressurized fuel tanks
15. NUMBER OF PAGES

70

16. PRICE CODE

\begin{tabular}{l|l|l|l|}
\hline $\begin{array}{l}\text { :SECURITY CLASSIFICATION } \\
\text { OF REPORT }\end{array}$ & $\begin{array}{l}\text { 18. SECURITY CLASSIFICATION } \\
\text { OF THIS PAGE }\end{array}$ & $\begin{array}{l}\text { 19. SECURITY CLASSIFICATION } \\
\text { OF ABSTRACT }\end{array}$ & 20. LIMITATION OF ABSTRACT \\
\hline
\end{tabular}

